Portland State University

PDXScholar

\title{
Modeling Surface Roughness as an Indicator of Age and Landslide Susceptibility, and the Spatial Inventory of Prehistoric Landslides: Green River Valley, Washington
}

Rebecca Naomi Garriss

Portland State University

Follow this and additional works at: https://pdxscholar.library.pdx.edu/open_access_etds

Part of the Geology Commons

Let us know how access to this document benefits you.

\section{Recommended Citation}

Garriss, Rebecca Naomi, "Modeling Surface Roughness as an Indicator of Age and Landslide

Susceptibility, and the Spatial Inventory of Prehistoric Landslides: Green River Valley, Washington" (2019). Dissertations and Theses. Paper 5175.

https://doi.org/10.15760/etd.7051

This Thesis is brought to you for free and open access. It has been accepted for inclusion in Dissertations and Theses by an authorized administrator of PDXScholar. Please contact us if we can make this document more accessible: pdxscholar@pdx.edu. 
Modeling Surface Roughness as an Indicator of Age and Landslide Susceptibility, and the Spatial Inventory of Prehistoric Landslides: Green River Valley, WA

\author{
by \\ Rebecca Naomi Garriss
}

A thesis submitted in partial fulfillment of the requirements for the degree of

Master of Science

in

Geology

Thesis Committee:

Adam Booth, Chair

Scott Burns

Andrew Fountain

Jonathan Perkins

Portland State University

2019 


\begin{abstract}
Developing detailed landslide inventory maps of prehistoric landslides is essential to interpret the frequency and conditions under which slopes have failed. When coupled with age estimates, landslide inventories can yield better predictions for future slope failures, thereby improving hazard assessments and increasing chances for mitigation. Developing proxies for landslide age is an important area of research, but age dating prehistoric landslides can be challenging due to sparse datable organic material within landslide deposits, and to time or access constraints. In this thesis, surface roughness of the landslide deposit is used to construct a best-fit age-roughness model that quantitatively assigns age based on smoothing of the deposit with time for landslides in the Green River Valley (GRV), located in King County, Washington. Hillslopes in the valley are composed of glacial sediments and are prone to failure caused by three main triggers: over steepening caused by lateral migration of the Green River, Holocene climatic change (precipitation and temperature), and seismicity (Cascadia Subduction Zone and the Seattle Fault). We examine the distribution of landslides in the GRV using high-resolution lidar data and find a threshold relief of approximately $60 \mathrm{~m}$ corresponds to landslide locations. Four dated samples with ages ranging from 492 to 0 cal. BP defined age-roughness models that showed 44 to 51 of the 61 mapped landslides occurred from 5000 to $100 \mathrm{cal}$. BP, after the climate changed to cooler and wetter conditions. These 61 landslides, on average, decrease in age as you move upstream, consistent with upstream migration of a knickzone. From these age-roughness models the GRV has a recurrence interval of one landslide every 38
\end{abstract}


years since 1000 cal. BP (26 landslides/1000 years), which has implications for managing landslide hazards. 


\section{Acknowledgements}

I would first like to thank my thesis advisor Dr. Adam Booth from the Geology department at Portland State University. He was always able to answer my questions and help me with any number of problems I ran into as this work was evolving and changing. He was patient as I was finishing up and always understanding of my duties outside of working on this thesis. I am very grateful for his guidance in completing this work.

I would also like to thank my committee members Dr. Andrew Fountain, Dr. Scott Burns, and Dr. Jonathan Perkins. Their feedback and comments on my research were extremely valuable. I also really appreciate their flexibility and understanding with scheduling and completing this work.

A very special thank you to all the graduate and undergraduate students I shared an office, classroom, or beer with for the never ending support and pep talks. And to all the faculty in the Geology office who were available to answer any number of random thesis or non-thesis related questions.

I am also grateful for my family and friends who provided me with a limitless supply of love, patience, and support. Especially thankful for those friends and family who often checked in on me, offered me help, or just gave me positive words of encouragement.

I'm especially thankful for my undergraduate thesis advisor, Dr. Michele Cooke. She provided the foundation for me to stand on to feel confident and proud of the work I am doing. Her open door policy and emotional support gave me the confidence to pursue and complete my graduate degree in an area of study I was very passionate about.

Special mention to my supervisors and co-workers who gave me positive words of encouragement, allowed for time off to finish my writing, and especially to those who read my thesis and gave me feedback. Without them I would not be actively working on becoming an Engineering Geologist.

And finally, last but not least, I would like to thank my dog Blues. He took many long naps, never complained when the walks were short, and told me funny jokes. Whenever I needed a break, he was/is always there to accompany me on any outdoor adventure. Blues is a good boy. 


\section{Table of Contents}

\section{Page}

Acknowledgements

iii

List of Tables

$\mathrm{V}$

List of Figures

vi

1. Introduction 1

1.1 Study Area 5

$\begin{array}{lll}2 . & \text { Methods } & 14\end{array}$

2.1 Landslide Deposit Mapping $\quad 15$

2.2 Radiocarbon Dating 20

$\begin{array}{lll}2.3 & \text { Roughness Analysis } & 22\end{array}$

3. Results 24

3.1 Spatial Patterns of Landslides 24

3.2 Roughness and Evaluation Against Relative Ages 31

3.3 Radiocarbon Dating 36

$3.4 \quad$ Age Roughness Models $\quad 40$

4. Analysis \& Discussion 47

4.1 Spatial Patterns of Landslides $\quad 47$

4.2 Roughness-based Relative Ages 59

$\begin{array}{lll}4.3 & \text { Radiocarbon Dating } & 62\end{array}$

4.4 Preliminary Age Roughness Model and Landslide Timing 64

$\begin{array}{lll}4.5 & \text { Future Work } & 70\end{array}$

$\begin{array}{ll}\text { 5. Conclusion } & 71\end{array}$

$\begin{array}{lll}\text { 6. } & \text { References } & 75\end{array}$ 


\section{List of Tables}

Page

Table 1: $\quad$ The seven dated samples with their radiocarbon and calibrated 38 ages.

Table 2: $\quad$ Radiocarbon dated samples with their calibrated dates and their 43 modeled absolute ages in 3, 15, and $30 \mathrm{~m}$ window sizes. 


\section{List of Figures}

Page

Figure 1: Diagram showing landslide deposit smoothing as it ages 4

Figure 2: $\quad$ Map of the Green River Valley study area in King County, WA 7

Figure 3: Geologic Map of the Green River Valley 8

$\begin{array}{ll}\text { Figure 4: } & 12\end{array}$

Figure 5: Age-roughness model by LaHusen et al., 2016

$\begin{array}{lll}\text { Figure 6: } & \text { Aerial/lidar comparison of study site } & 17\end{array}$

Figure 7: $\quad$ Current landslide inventory map from kingcounty.gov of the GRV 18

Figure 8: $\quad$ Boundary of landslide deposits pre and post buffering 19

Figure 9: $\quad$ Picture of an ideal sample site with woody debris 21

Figure 10: $\quad$ Picture of sample site with pre-LGM mobilized woody debris 21

Figure 11: Example of hillshade, slope, roughness raster, and zonal statistics 23

Figure 12: Landslide deposit inventory map of the GRV 26

Figure 13: Landslide deposit maps showing distance in river and valley 27 kilometers

Figure 14: Elevation map and river gradient showing knickzone of the GRV 28

Figure 15: Plot showing the area of landslides in relation to the knickzone 29

Figure 16: Graph of the number of landslides versus local relief on the north 30 and south side

Figure 17: $\quad$ Graph of the number of landslides versus valley bottom width 31

Figure 18: Map of landslide deposits with their average roughness 33

Figure 19: Map of landslide deposits that share cross cutting relationships 34

Figure 20: Map of roughness values from only the $3 \mathrm{~m}$ window matching 35 a landslide pair

Figure 21: Map of roughness values from only the $30 \mathrm{~m}$ window matching 35 a landslide pair

Figure 22: $\quad$ Sample site location map 36 
Figure 23: Oxcal calibrated radiocarbon ages of samples 37

Figure 24: $\quad$ Map of the 7 samples with their calibrated year of occurrence $\quad 39$

Figure 25: $\quad$ Modeled age-roughness curve for the 3 meter, 15 meter, and $30 \quad 42$ meter window size

Figure 26: Landslide deposit with lowest average standard deviation of slope 43 in study area

Figure 27: Histograms of four age-classification groups for all three window 45 sizes

Figure 28: $\quad$ Subdivided age groups from the Prehistoric-Young (100-5000 46 cal. BP) age group

Figure 29: $\quad$ Lateral migration of the Green River from 1936 to $2017 \quad 50$

Figure 30: Aerial photo comparison from 1936 to 1998 showing lateral 51 migration of the river

Figure 31: Map showing sample site locations within the lateral migration 52 area

Figure 32: $\quad$ Map showing sample site TB3 from lidar and aerial photos $\quad 53$

Figure 33: $\quad$ Map showing the three landslides with ages consistent with the $\quad 58$ Osceola Mudflow

Figure 34: Cross cutting relationships all three window sizes did not match 62

Figure 35: $\quad$ Map showing landslides with assigned age group based on average 67 SDS values

Figure 36: $\quad$ Map showing the Prehistoric-Young age group subdivided per 68 1000 years

Figure 37: Bubble plot with predicted ages, distance upstream, and landslide 69 area

Figure 38: Graph showing number of landslides per 1000 years for the $3 \mathrm{~m} \quad 69$ window 


\section{Introduction}

Landslides occur in different types of geologic environments from external events such as climatic change, tectonic events, and stream incision, or from internal changes such as weathering (Palmquist and Bible, 1980). Slopes can fail without warning with very high velocities and long debris run outs, posing a serious threat to communities and causing enormous property damage (Chen et al., 2013; Haugerud, 2014; Iverson et al., 2015; Wartman et al., 2016). In tectonically active regions (e.g. the Himalayas and Pacific Northwest), erosion rates tend to balance rock uplift rates with hillslope erosion set primarily by the frequency of slope failure (Montgomery and Brandon, 2002; Larsen and Montgomery, 2012). When hillslopes are near a threshold angle, landslide erosion rates will increase in response to increases in river incision caused by rapid uplift rates (Larsen and Montgomery, 2012).

The three basic triggering mechanisms for landslides are base level lowering caused by stream incision, climate, and seismic shaking (Palmquist and Bible, 1980). Base level lowering includes stream incision in response to tectonic uplift and isostatic rebound, which raises the stream channel causing it to have a steeper gradient and an increased incision rate (Zhang et al., 2014). In narrow valleys the hillslopes bordering the channel are steepened by incision with the toe being continuously eroded and resulting in decreased stability. Wider valleys preserve more prehistoric landslides as the toes of their deposits are often protected by stream terraces.

Climate induced landslides can result from increased subsurface water pressure that decreases shear strength (Caine, 1980; Guzzetti et al., 2008). Temperature can play an indirect role as cooler climates will decrease evapotranspiration and increases the amount 
of resident ground water. More shallow water tables increases the pore water pressure which results in slope instability. A wetter climate can also increase stream incision by increasing stream discharge.

Earthquake induced landslides can fail during shaking due to a decrease in effective normal pressure caused by an increase in pore water pressure from compaction, or from direct changes to the shear and normal stresses caused by ground accelerations. Slumps, earthflows, rock falls, slides, and avalanches have all been caused by seismic shaking (Keefer, 1984). Although landslides will cluster around the location of the fault, they can occur anywhere an earthquake is felt (Karlin et al., 2004). Areas of instability can continue long after the earthquake due to fractures in hillslopes caused by shaking, which provide preferential flow paths for infiltration (Marc et al., 2016) and weaken the materials.

In landslide prone regions, considerable resources have been expended constructing susceptibility maps that portray the spatial probability of landslide occurrence (Chen et al., 2013). Landslide hazard maps are important for social and economic purposes when considering many people live on and around hillslopes. Regions with the highest landslide susceptibility are identified by where past landslides have occurred, necessitating detailed mapping of existing landslides. Data retrieved from the surface of a landslide may provide more understanding of the relationship between landslide activity and material type (Glenn et al., 2006). Precise mapping of landslide deposits to create a landslide inventory is now commonly done using lidar data and limited field verification (Burns \& Madin, 2009), with relative ages often crudely estimated by the degree of surface smoothing and cross-cutting relationships with adjacent slope failures (Haugerud, 2014). As time increases, roughness of the landslide deposit decreases as soil transport slowly erodes the hummocky 
topography that formed after the debris settled (Figure 1) (McCalpin, 1984). Several parts of a landslide offer clues to its age, including the intensity of dissection by gullies, smoothness of the hummocks, and shape of the head scarp. The shape of the head scarp expands, becomes less acute, and decreases its slope angle as age increases due to scarp diffusion by erosion (McCalpin, 1984), similar to fault scarps (Hanks, 2000) and terrace risers (Anderson et al., 1999). Similarly, scarps and hummocks within the landslide deposit smooth over time, which is the focus of this thesis. The erosion rate decreases with time as the slope of the landslide from the scarp to the toe becomes less steep (Roering et al., 2001), so the rate of change of surface roughness should also decrease with time. Mapping with high-resolution lidar allows us to clearly identify and isolate parts of landslide complexes that may have different activities. Previous broad areas of instability in the Columbia River Gorge were found to consist of multiple smaller landslides within a larger landslide complex (Pierson et al., 2016). Existing landslide deposits are often weak which causes them to fail (remobilize) repeatedly (Burns \& Mickelson, 2016). Decreased material strength of the deposit results from increased permeability, and topographic changes along the surface, such as steep slopes from scarps and toes (Burns \& Mickelson, 2016). Inventorying previously failed slopes and the conditions under which they failed is important to understanding what the landslide susceptibility is of a given region (Burns \& Mickelson, 2016).

Precisely dating landslide deposits and comparing those dates to independent climatic and tectonic records may potentially allow us to define the conditions under which the slope failed and quantitatively estimate landslide recurrence intervals. Given the episodic nature of landslide frequency requires dating prehistoric events. The most popular 
and widely applied method to date prehistoric landslides is Carbon-14 dating of woody debris entrained in the deposit (Panek, 2015). However, finding exposed samples of woody debris can be difficult.

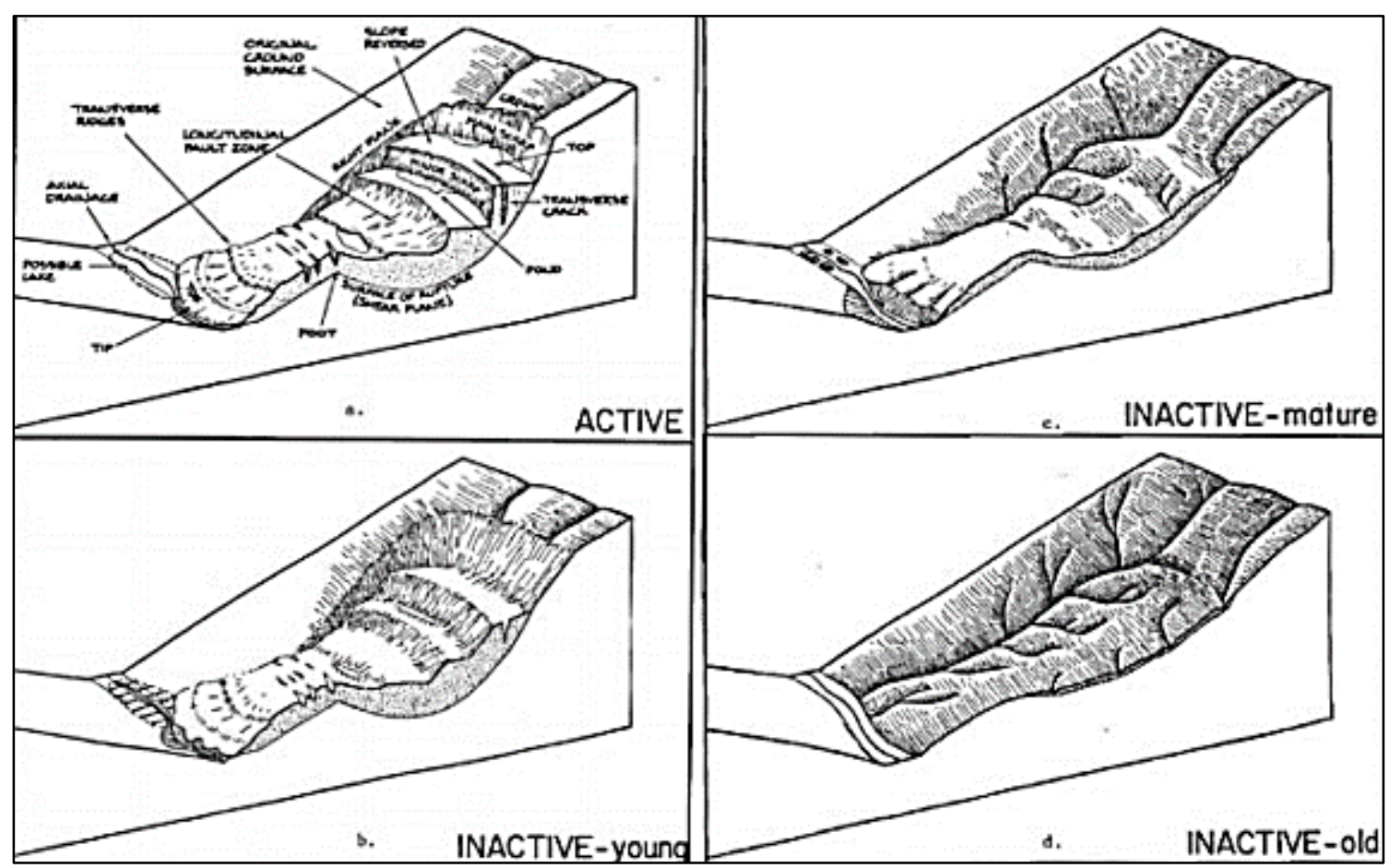

Figure 1. Diagram showing the deposit of the landslide being eroded and smoothed out over time (McCalpin, 1984).

An alternative method to date prehistoric landslide deposits is evaluation of surface roughness with the understanding that the landslide deposit smooths as it gets older. This can be crude, but combining carbon dating with surface roughness may increase the accuracy of roughness methods already demonstrated. The purpose of this study is to calculate an age-roughness model for landslide deposits in the Green River Valley (GRV), Washington. I will then compare landslide timing to climate to determine if a causal link can be established and provide a better understanding of landslide susceptibility. 


\subsection{Study Area}

The Green River Valley is an ideal location to test a surface-roughness model because of its large number of landslides, well known geology, and maximum age constraint from the last recession of the Cordilleran Ice Sheet. The GRV's main river system is the 105-kilometer-long Green River, located in King County, Washington (Figure 2). Starting in the Western Cascade Mountains, it travels in a west to northwest direction, draining into eastern Puget Sound next to the city of Seattle (Mullineaux, 1970). The GRV was formed post-glacially during and after the retreat of the Cordilleran Ice Sheet around 16,420 cal. BP (Mullineaux, 1970; Porter \& Swanson, 1998). All ages in this thesis are given as calibrated years before present (cal. BP). Hillslopes on either side of the valley in the western section of the study area consist primarily of unconsolidated Pleistocene glacial deposits overlain by thin postglacial sediments from floodplain, delta, and lacustrine deposition (Mullineaux, 1970; Thorsen, 1989). The southwestern side of the valley is also overlain by Osceola Mudflow deposits from phreatomagmatic eruptions on Mt. Rainier that occurred approximately 5,600 cal. BP (Mullineaux, 1970; Vallance \& Scott, 1997) (Figure 3). The eastern side of the study area, where the valley is a gorge, has Tertiary age sedimentary bedrock along the valley walls (Vine, 1969). After the ice sheet melted, isostatic rebound of approximately 30 to $40 \mathrm{~m}$ occurred within the study area (Thorson, 1981) allowing base level of the drainage to lower. The Green River incised into the bedrock forming a deep gorge (Mullineaux, 1970; Neal \& Coover, 1995). The underlying geology is relevant because landslides may occur more often in one type of geologic unit than another due to different geotechnical properties and more often where two geologic units meet (Wartman et al., 2016; Perkins et al., 2017). Till, outwash and lacustrine glacial 
deposits all with different cohesions, hydraulic conductivities, and angles of failures are mapped in the GRV (Perkins et al., 2017).

Prehistoric landslides in the GRV are dominated by sediment deposited by the Cordilleran Ice Sheet in the Puget lowlands prior to 16,420 cal. BP (Porter and Swanson, 1998), an age range that is well-suited to radiocarbon dating. Additionally, previous work that tested surface roughness of landslide deposits as a proxy for age in the North Fork Stillaguamish River (NFSR) in Northern Washington, which has similar glacial sediments, showed that those landslides must have failed at different times in the past 12,000 years (LaHusen et al., 2016; Booth et al., 2017). Although roughness can reflect landslide activity, in the GRV it is more likely to primarily reflect age because most landslides appear to have failed in a similar style and involved similar materials. The glacial sediments in which the landslides occurred are relatively uniform throughout the study area, allowing us to control for material type, which exerts a strong control on landslide type in the Puget Lowlands (Perkins et al., 2017). Constraining the ages of prehistoric landslides may allow us to determine if they were triggered by climatic or tectonic events by comparing landslide frequency to independent records of those triggering mechanisms. 


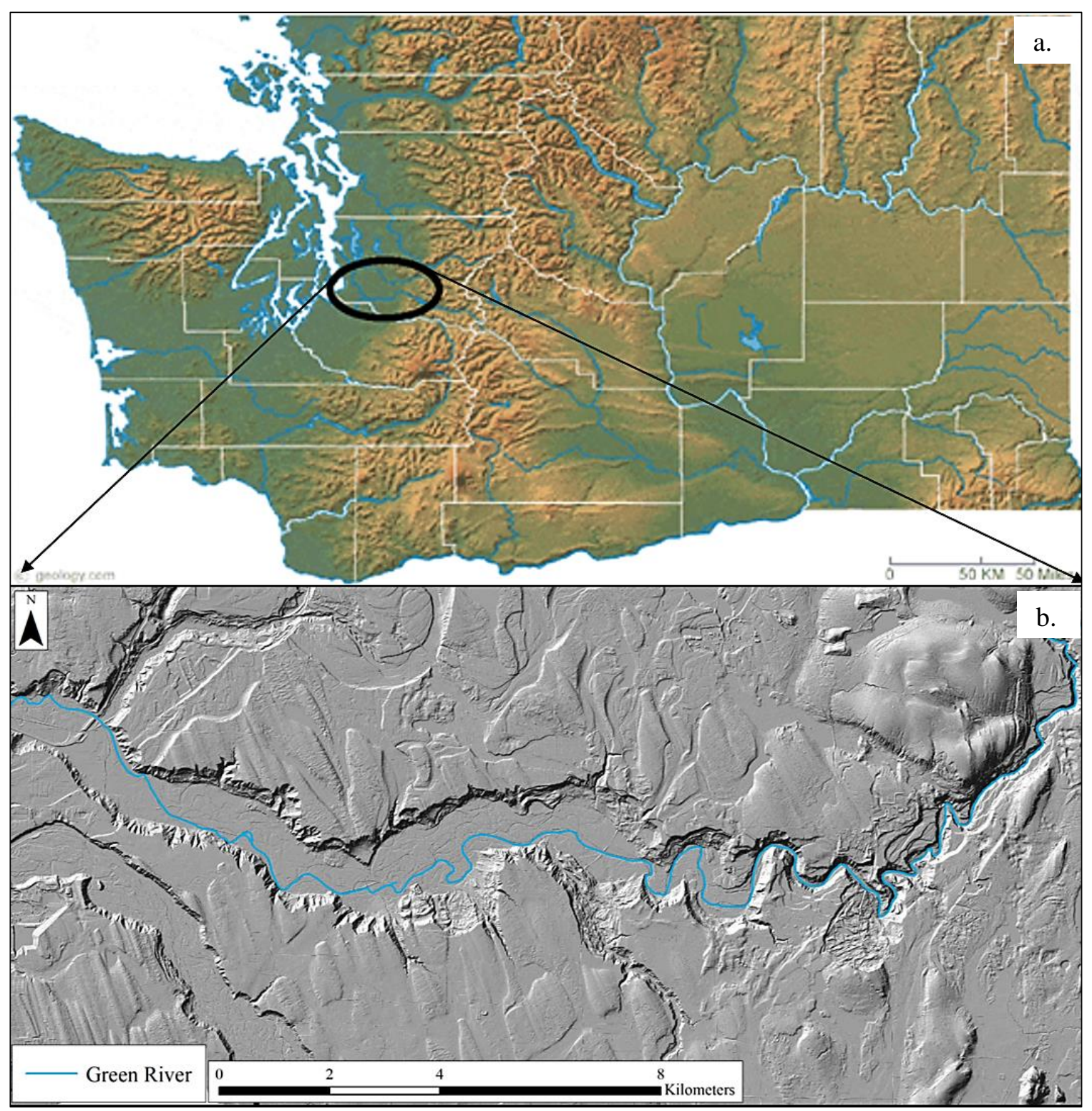

Figure 2. (a) Map showing the location of the Green River Valley (black oval) in Southern King County, Washington, and (b) a close up of the study area in lidar hillshade. 


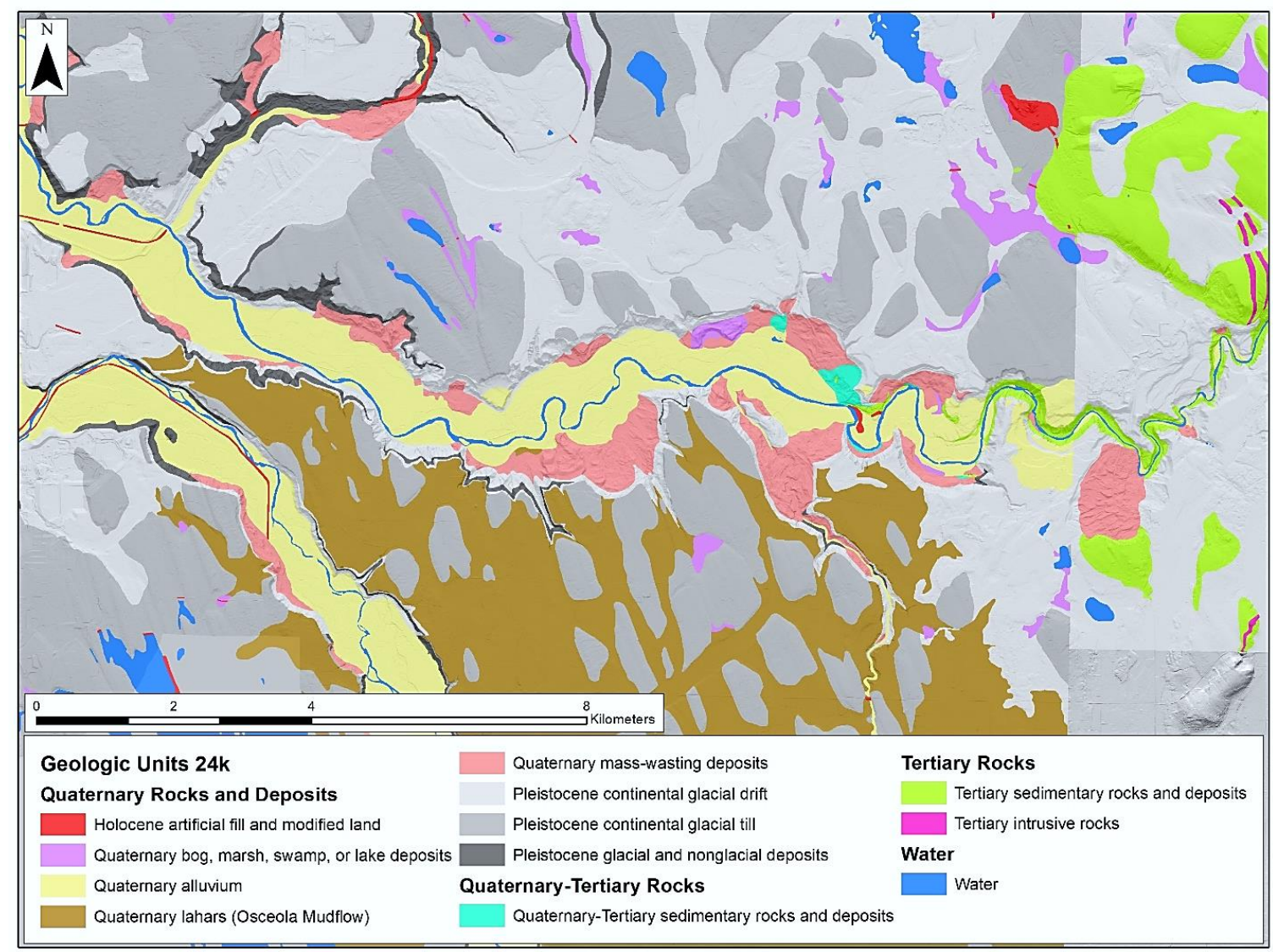

Figure 3. Geologic Map of the Green River Valley, King County, Washington (modified from Vine, 1969; Mullineaux, 1970).

Climatic conditions in the study area may also play a major role in slope failure. The maximum glaciation at around 16,420 cal. BP (Porter and Swanson, 1998) experienced dry-cold easterly airflows that formed above the ice sheet (Brubaker, 1991). After the ice sheet retreat, by around 10,000 cal. BP, the climate had warmed and caused severe summer droughts and frequent fires (Brubaker, 1991). During the mid-Holocene, at around 6,000 cal. BP, a decrease in charcoal found in lake bottom cores suggests a transition to the cooler and wetter modern climate similar to today in the Pacific Northwest (Brubaker, 1991). Making landslide hazard maps requires not only an understanding of failure in relation to tectonics but also knowing under which climatic conditions the slopes are most susceptible 
to failure. Correlating ages to a cooler and wetter climate in the past is useful when considering our current climate (Brubaker, 1991; Booth et al., 2017).

Identical or overlapping ages of landslides in the proximity of active faults is one of the most reliable indicators of a paleo-earthquake event (Panek, 2015). Seismicity in the GRV can come from either shallow crustal faults $(<20 \mathrm{~km}$ deep $)$ such as the Seattle or Tacoma Fault or from deep subduction zone faults (45 to $65 \mathrm{~km}$ deep) such as the Cascadia Subduction Zone (Clague, 1997). Paleoseismic history prior to the Holocene in this region is challenging to infer due to the extent of the last glaciation (Porter and Swanson, 1998: Arcos, 2012). Glacial erosion and deposition masks any surface expression of paleoseismicity prior to that time (Arcos, 2012). Some previously dated landslides in the NFSR correlate to the Seattle Fault rupture approximately 1,000 cal. BP, while the oldest directly dated slide there has an age of 6,000 cal. BP (LaHusen et al., 2016; Booth et al., 2017).

The Cascadia Subduction Zone is a $1000 \mathrm{~km}$ long rupture zone that parallels the Pacific coastline from northern California to central Vancouver Island in southern Canada (Clague, 1997). In the last 4,000 years seven major earthquakes, with an average recurrence interval of 500 years, are inferred to have ruptured all or portions of the zone (Clague, 1997). The most recent earthquake associated with the subduction zone occurred in 1700 A.D., which was determined from radiocarbon dating and tree ring correlations from submerged forests along the Pacific Coast and Lake Washington in Washington State (Jacoby et al., 1997; Yamaguchi et al., 1997).

Of the crustal faults in the Pacific Northwest, the Seattle Fault poses the highest risk to the region due to its location directly beneath Seattle, the largest city in the state of 
Washington (Liberty, 2009). Seismic profiles have been used to constrain the location, shallow structure, and displacement rates. A $50 \mathrm{~km}$ long seismic profile indicates that the Seattle Fault zone is comprised of a 4-6 km wide zone of three or more south-dipping reverse faults (Johnson et al., 1999). Radiocarbon dates from uplifted terraces and tsunami deposits show the Seattle Fault's last major earthquake happened approximately 1,000 cal. BP (Atwater and Moore, 1992; Bucknam et al., 1992; Jacoby et al., 1992; Liberty, 2009). Another way scientists have constrained the age of the last large earthquake on the Seattle Fault is by radiocarbon dating samples found in Lake Washington landslide deposits inferred to have failed due to the rupture of the fault (Jacoby et al., 1992). Lake Washington is located on the Eastern boundary of Seattle in a tectonically active area above at least four strands of the Seattle Fault (Karlin et al., 2004). These four strands are obscured by landslide debris from "block slides, sediment slumps, and debris flows" (Karlin et al., 2004). Some of the larger landslides that failed into Lake Washington have scarp to toe lengths of 500-750 meters, suggesting that they failed during a large tectonic event (Jacoby et al., 1992).

A Modified Mercalli Intensity (MMI) of 5-6 is the minimum needed to trigger landslides (Keefer, 1984; Panek, 2015). The Seattle Fault's last major earthquake has been estimated to have had a magnitude of 7 or larger (Bucknam et al., 1992), which would cause shaking of approximately 8 to 9 on the MMI scale within approximately $20 \mathrm{~km}$ of the surface rupture (Rashed, 2003). Current seismic shake maps of Washington show that the GRV will experience strong to severe shaking, corresponding to an MMI of 6.5 to 7.5 , if the Seattle fault zone or Cascadia Subduction zone were to rupture again and only slightly less shaking, corresponding to an MMI of 6.0 to 7.0 if the Tacoma Fault zone were to 
rupture again (Figure 4) (https://earthquake.usgs.gov/scenarios/). Although current seismic shakemaps show that rupture of the Seattle Fault and the Cascadia Subduction zone would produce approximately the same MMI throughout the study site, it is probable the GRV could experience more severe shaking from a Seattle Fault rupture (CREW, 2008). This is due in part to the location of the earthquake focus (point of rupture below surface) and how far the GRV is from each. Earthquakes originating from shallower depths can have more severe shaking because the seismic waves produced at the point of rupture have a shorter distance to travel to the surface which means their energy is less dispersed (CREW, 2008). The danger of the Seattle Fault is that its focus is much shallower (making shaking much more intense) at depths of 16 to 24 kilometers, whereas the Cascadia Subduction Zone earthquakes originate from depths of $30 \mathrm{~km}$ (at the offshore subduction zone) to $80 \mathrm{~km}$ (on the down going plate near shore) (Clague, 1997; Yeats, 2004).

Previous work in the Puget Lowlands has indicated that the climatic shifts and seismic shaking described above likely affected the frequency of landsliding in glacial sediments (LaHusen et al., 2016; Booth et al., 2017). This frequency was determined by developing an age-roughness model for the North Fork Stillaguamish River in which landslide deposit roughness is negatively correlated with the age of the landslide (Figure 5) (LaHusen et al., 2016). This is consistent with near surface soil transport causing the surface of the landslide to smooth out as age increases. 


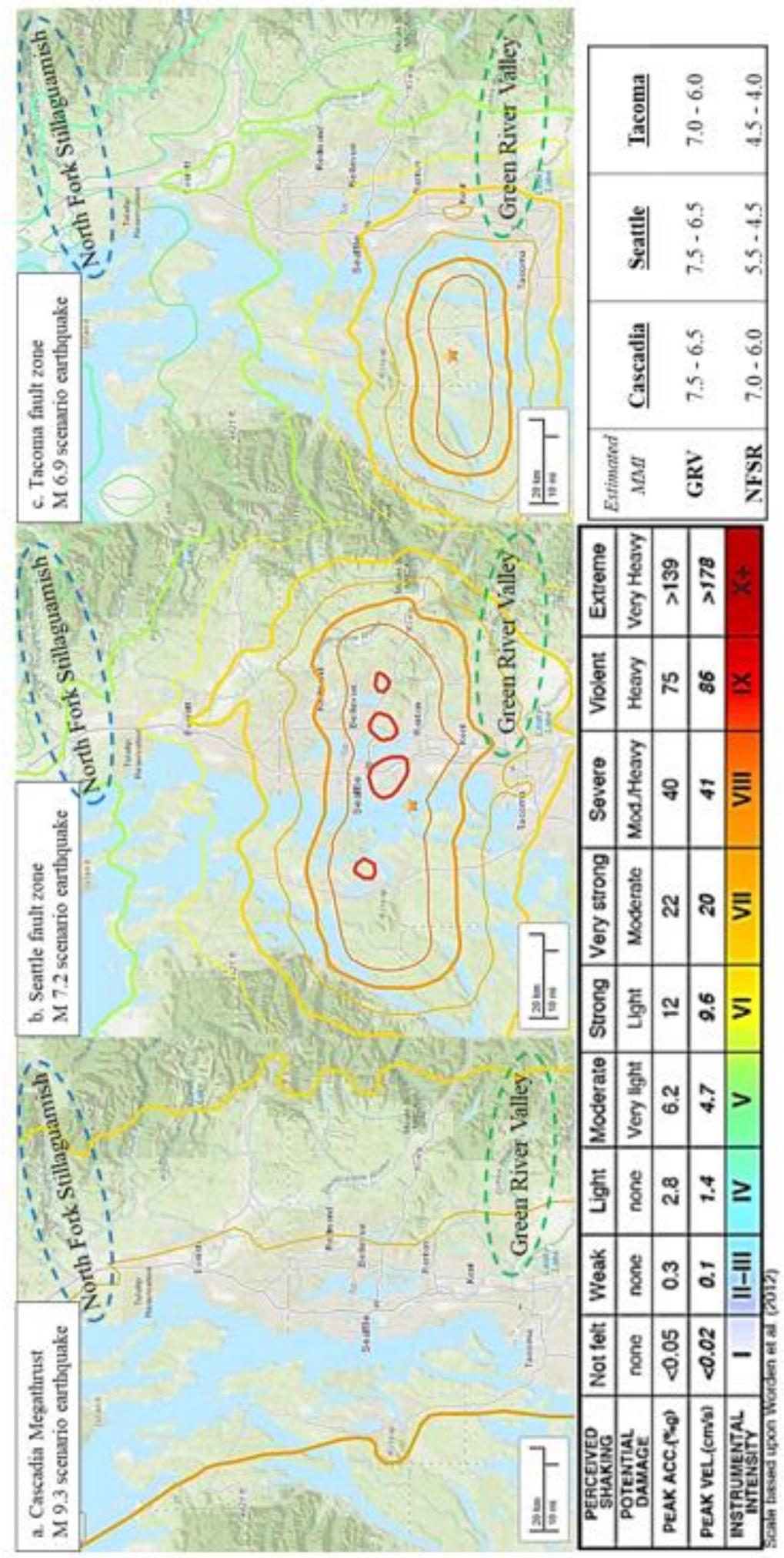

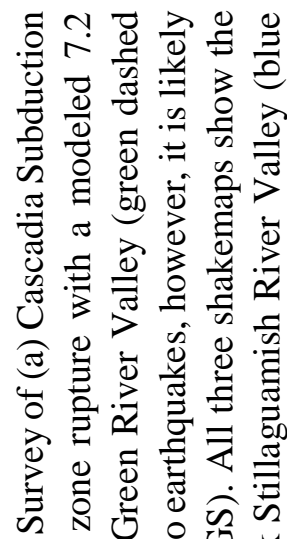

.

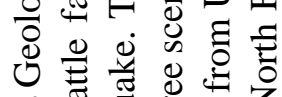

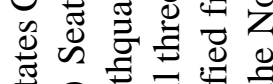

劳 乞

.气

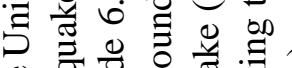

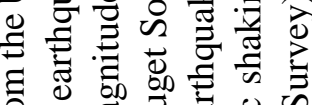

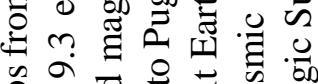

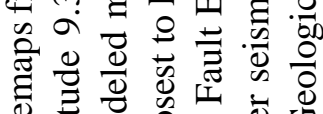

¿

స్

क छ

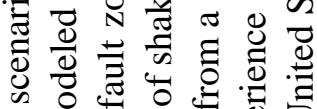

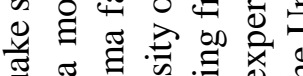

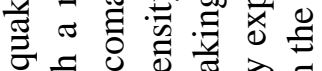

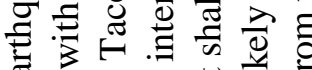

¿ (2)

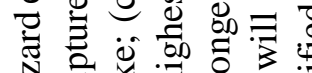

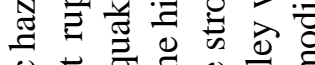

.

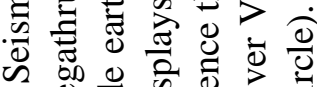

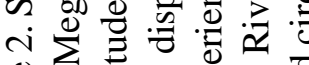

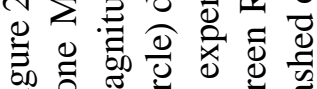

江 


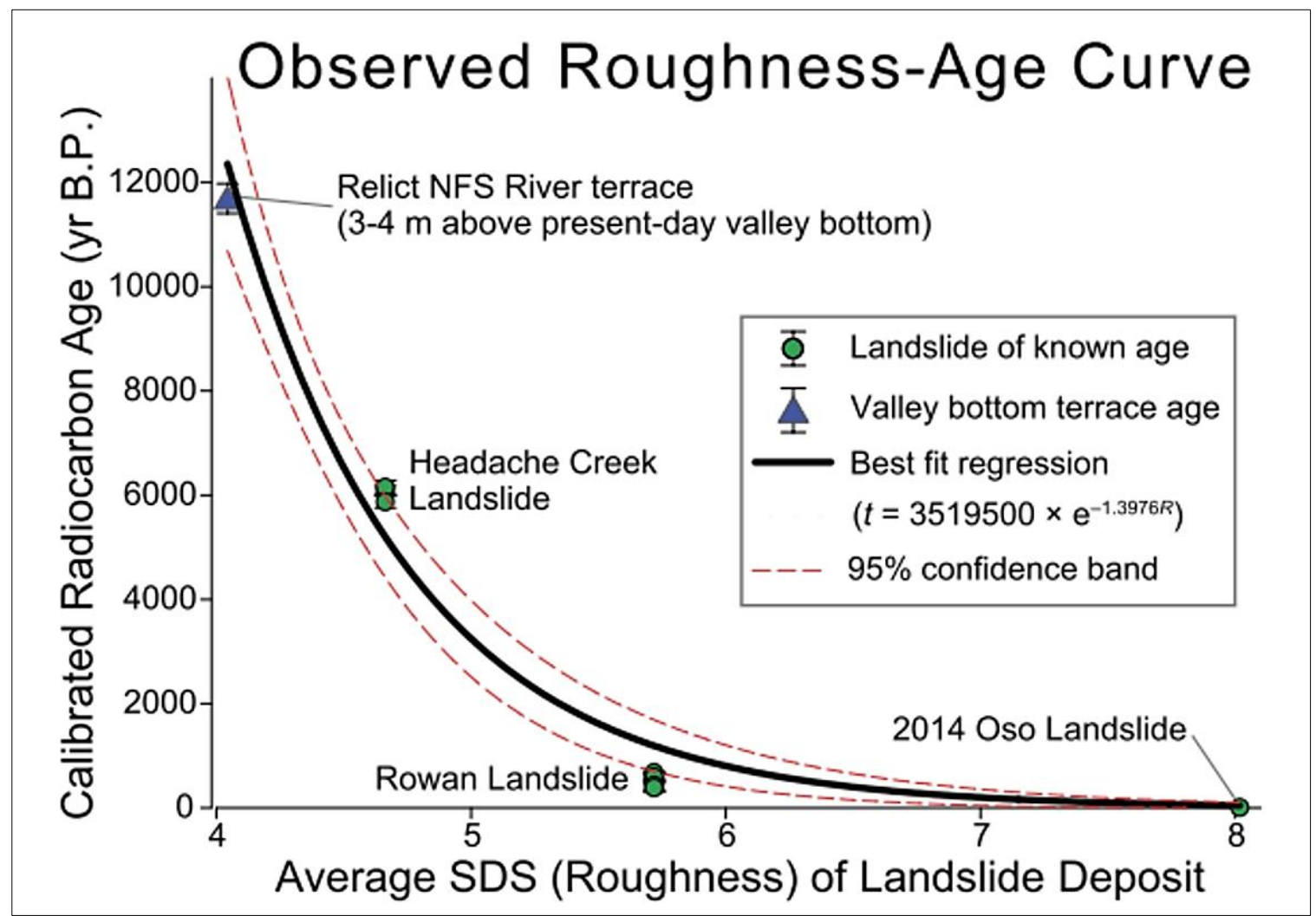

Figure 5. Age-roughness model using the standard deviation of slope (SDS) in the North Fork Stillaguamish River (LaHusen et al., 2016). 


\section{Methods}

My goal is to document the spatial pattern and relative timing of landslide failures. Surface roughness is used as a proxy for landslide age calibrated with a set of directly dated landslides. The first step was to map all the landslides within the study site. From this inventory, I chose sites to search for dateable organic material. Accessibility was an issue as some landslides are located on private property. Within the landslides, gullies and toes were the most likely locations for woody debris. Buried debris in the deposit is inferred to have been killed as the slope failed. Radiocarbon dates from the wood dated the slide. I also used the relative ages based on cross cutting relationships to statistically evaluate surface roughness as an indicator of landslide age. I defined surface roughness as the standard deviation of slope in a moving window of 3,15 , or $30 \mathrm{~m}$ width, and excluded roads and gullies within the deposit to get a natural representation of the surface roughness.

Other data acquired were the spatial location of landslides in relation to valley bottom width, local relief on the north and south sides of the valley, as well as the river gradient. Valley bottom width and local relief were measured at every valley kilometer while the gradient was measured at every river kilometer. This distinction is important because the distance along each is different due to river meander. For local relief, terrace and present day river elevations were measured at each valley kilometer on both the north and south side of the GRV and compared to the number of landslides on that side of the valley. Valley bottom width was the measure of distance between the north and south side river terraces. 
Mass wasting processes could have played a part in shaping areas of the GRV, or mass wasting could have responded to lateral migration of the river driven primarily by fluvial processes. To determine whether mass wasting was a cause or consequence of lateral migration, or neither, I analyzed the relationship between migration and historic landslides for the most actively migrating reach of the river. Although it is difficult to see prehistoric landslide features in aerial photos, there should be evidence of slope failure as exposed, bare ground if that were the cause of the river laterally moving. Lidar is helpful, but it only goes back 15-20 years, whereas aerial photos can go back to the early 1900s. Because the GRV has been modified by people who have built roads and structures, there are reliable stable landmarks, and I compare their locations in relation to the river and any potential slope movement.

\subsection{Landslide Deposit Mapping}

Landslides have been mapped using ground-based methods long before lidar became a widely available tool. However, prehistoric landslides are difficult to identify from the ground and from aerial and satellite-based photography. In many temperate zones and particularly in the Pacific Northwest, vegetation rapidly reclaims the landslide deposit and obscures its surface morphology (Figure 6). Lidar has an important advantage over other methods in identifying landslides due to its ability to penetrate vegetation and show fine topographic detail.

I used a lidar-based digital elevation model (DEM) flown in 2016 with 1-meter spatial resolution available through the Puget Sound Lidar Consortium (http://pugetsoundlidar. ess.washington.edu/). A landslide map (2016) was retrieved from 
the Washington Department of Natural Resources (https://www.dnr.wa.gov/) (Figure 7). The map was useful to identify the main landslide deposits, but the DEM required new deposit boundaries to be outlined where gullies and roads were eliminated as they would otherwise interfere with the roughness analysis. I used the DEM to derive a slope and hillshade map in ArcMap that helped to further define the extent of prehistoric landslide deposits in the valley. This was done by using current mapping protocols from the Oregon Department of Geology and Mineral Industries (DOGAMI) and the Washington Department of Natural Resources (WA DNR) to correctly identify the landslide deposit from other features such as the scarp, flanks, and toe (Burns \& Madin, 2009; Slaughter et al., 2017). Landslide deposits, identified by their hummocky topography, were initially mapped at scales ranging from 1:12,000 to 1:2,000 depending on their size. Once all the landslides were mapped I used a fixed scale of 1:4,000 to shift the polygons and ensure consistency in defining polygon boundaries (Burns \& Madin, 2009).

Gullies and roads within the landslide deposit were removed to minimize biased estimates of roughness (Figure 8). Roads can be difficult to identify at larger scales using lidar, so I also used aerial photographs and Google Earth. Unlike roads, gullies were easily identified using lidar, compared to aerial photographs, and were mapped manually. I deleted these features by using a buffer distance of $10 \mathrm{~m}$ from the center outwards. This distance was chosen to ensure human modification from building the road was not included in surface roughness. Gullies were given the same buffering distance of $10 \mathrm{~m}$ for consistency. Other landslide features deleted from the analysis included headscarps, since they are not part of the landslide deposit, and over-steepened toes caused by river erosion. 
As with gullies, river steepened banks are shaped by processes other than soil creep and can cause over-estimation of surface roughness.

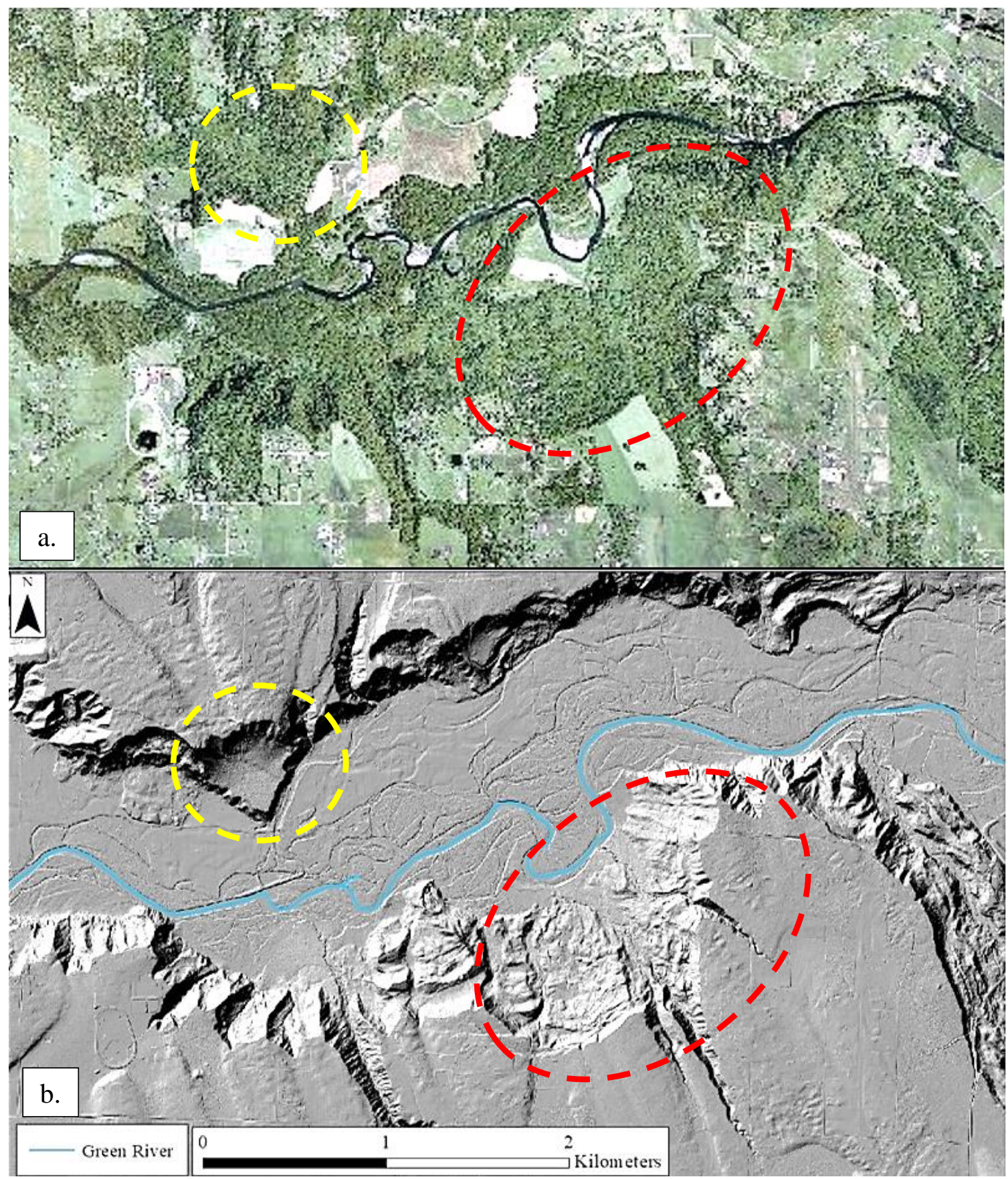

Figure 6. Comparison of (a) Aerial photograph and (b) Lidar-derived hillshade map of the same area in the Green River Valley. 


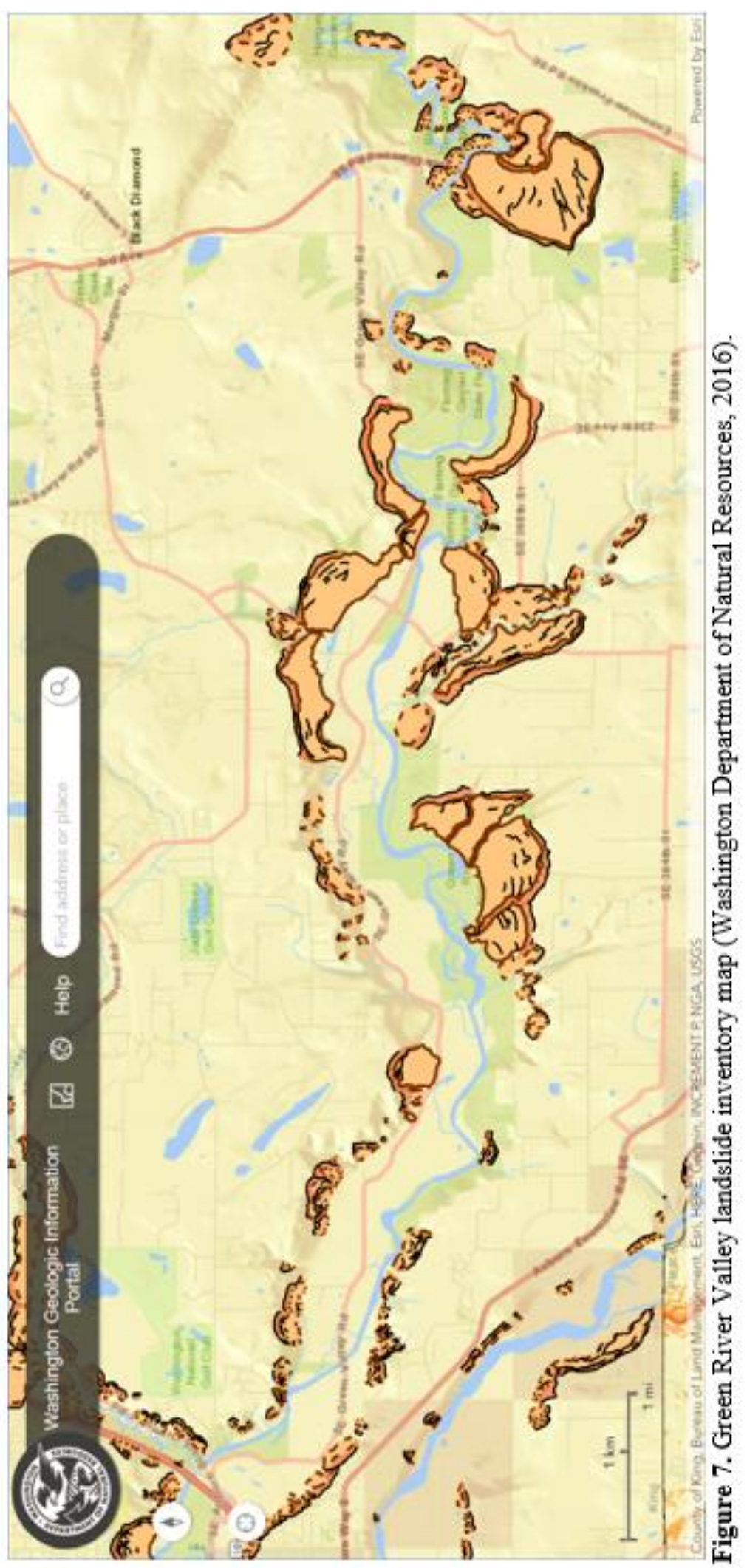




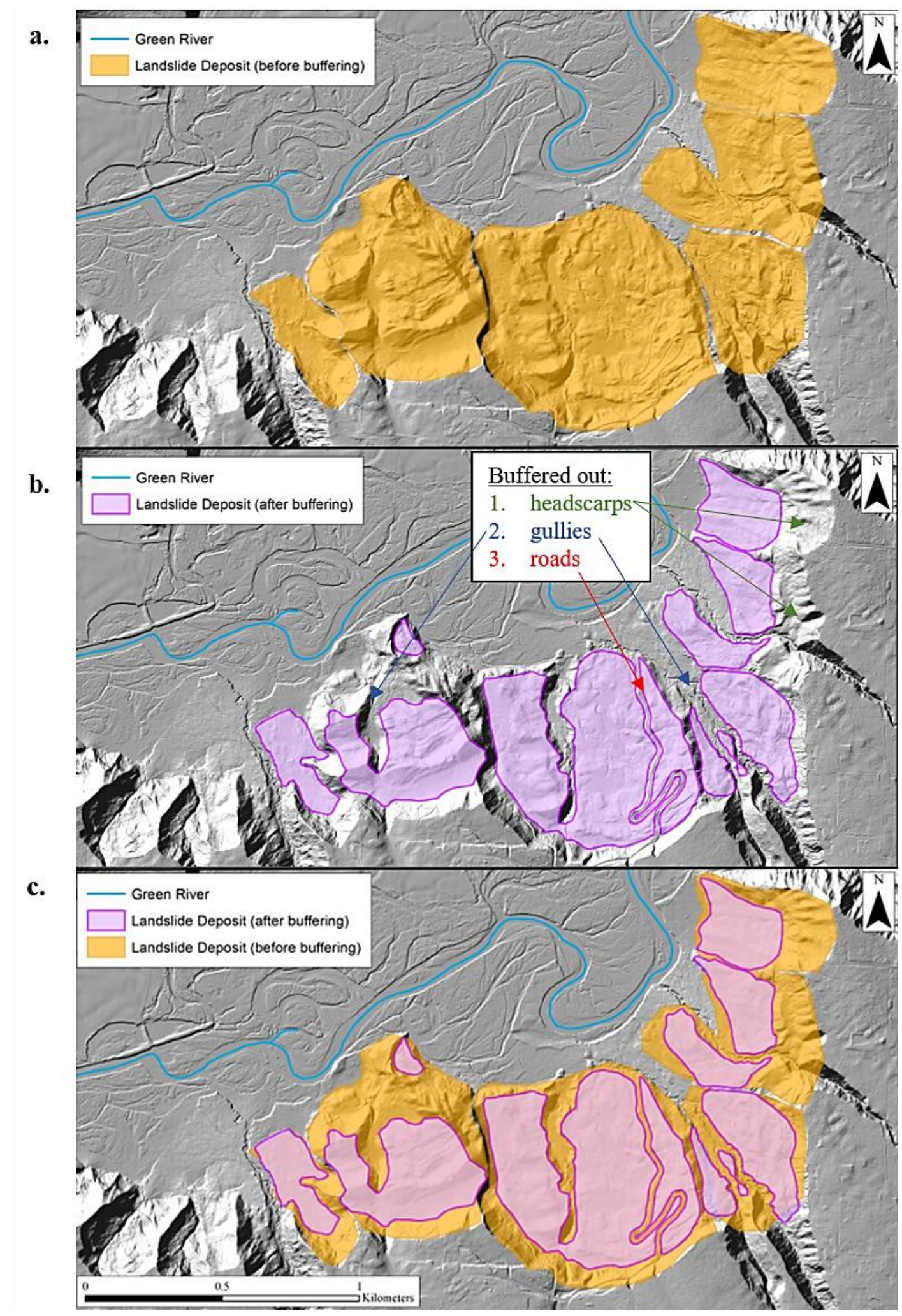

Figure 8. Example of (a) landslide deposits before buffering, (b) after buffering with headscarps, gullies, and roads removed, and (c) before and after overlay of the landslide deposits. 


\subsection{Radiocarbon Dating}

Woody debris is usually exposed in incised gullies formed in the landslide deposit, or at the toe of the landslide where it is exposed by river incision (Figure 9). Assigning the age of the sample to the age of a landslide assumes the tree was alive when the slope failed and became buried with the landslide deposit, so these dates are typically interpreted as a maximum age for the landslide. However, care must be taken as many landslides reactivate over time, remobilizing older organic material, or slowly creep rather than failing rapidly. Another consideration relevant to the GRV is that Last Glacial Maximum (LGM) sediment often contains woody debris that may be preserved and then re-worked in post-LGM landslides (Figure 10). Therefore organic material should only provide a maximum age for the landslide, which may be considerably older than the landslide itself (Panek, 2015). However, wood still provides the best age constraint for landslides in the Puget Lowlands because the region has been forested throughout the Holocene, and landslides would have likely entrained woody debris (LaHusen et al., 2016). I conducted an extensive field campaign from September 2016 to January 2018 that produced 12 samples of which 7 were radiocarbon dated.

The wood was dated at DirectAMS in Bothell, Washington and Beta Analytic in Miami, Florida. Samples of no less than $40 \mathrm{mg}$ to ensure testing viability were sent to each laboratory. Care was taken to collect the outer growth rings, the part of the sample that would most represent the age at which the tree died. Absolute ages returned may have analytical uncertainties of only 10s-100s of years, but overall uncertainty on the landslide's age is much larger, depending on what part of the wood (i.e. inner vs. outer growth ring) was dated and if the wood was dead before the landslide happened. Once radiocarbon ages 
were acquired, I converted them into calendar years before present (cal. BP) and cal AD using Oxcal radiocarbon calibration program, an online open source service (https://c14.arch.ox.ac.uk/calibration.html) (Ramsey, 2001).

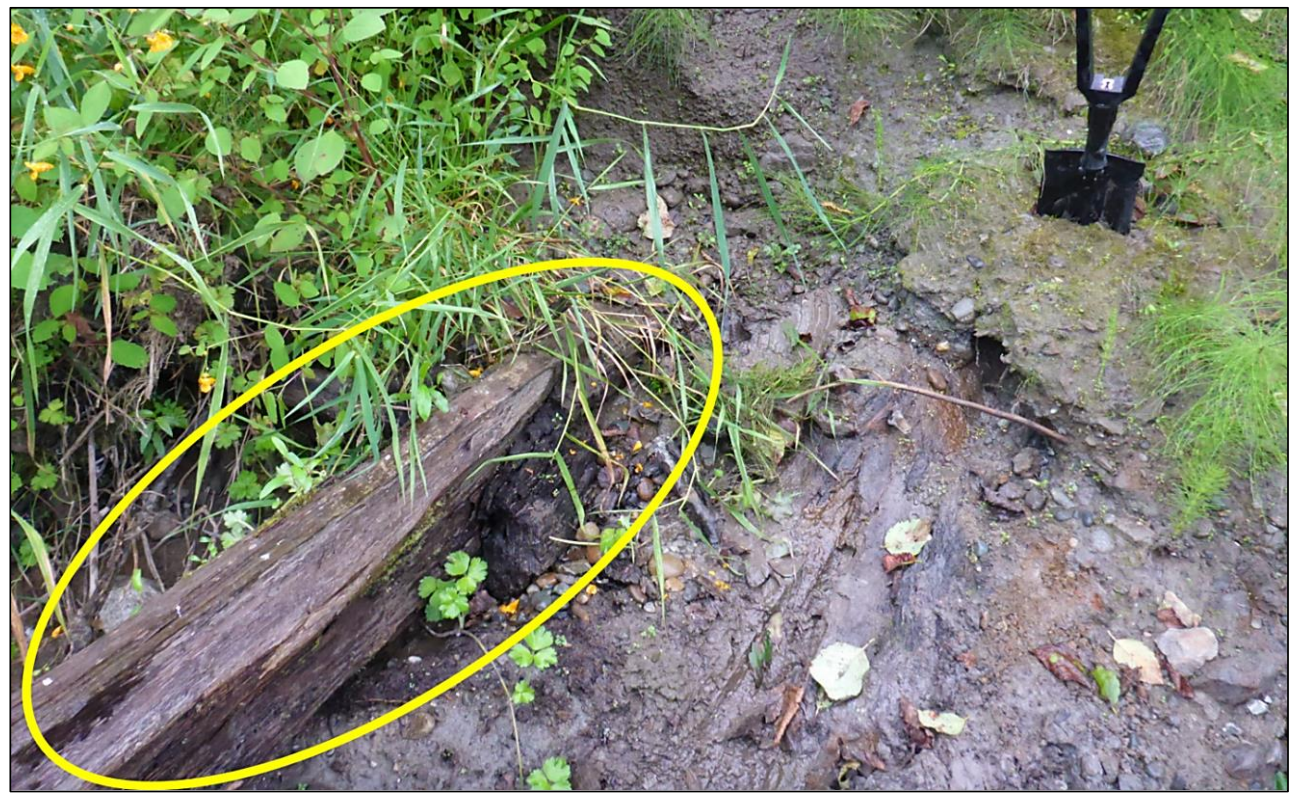

Figure 9. Example of a sample site with a log buried in sediment and exposed along the Green River (yellow oval).

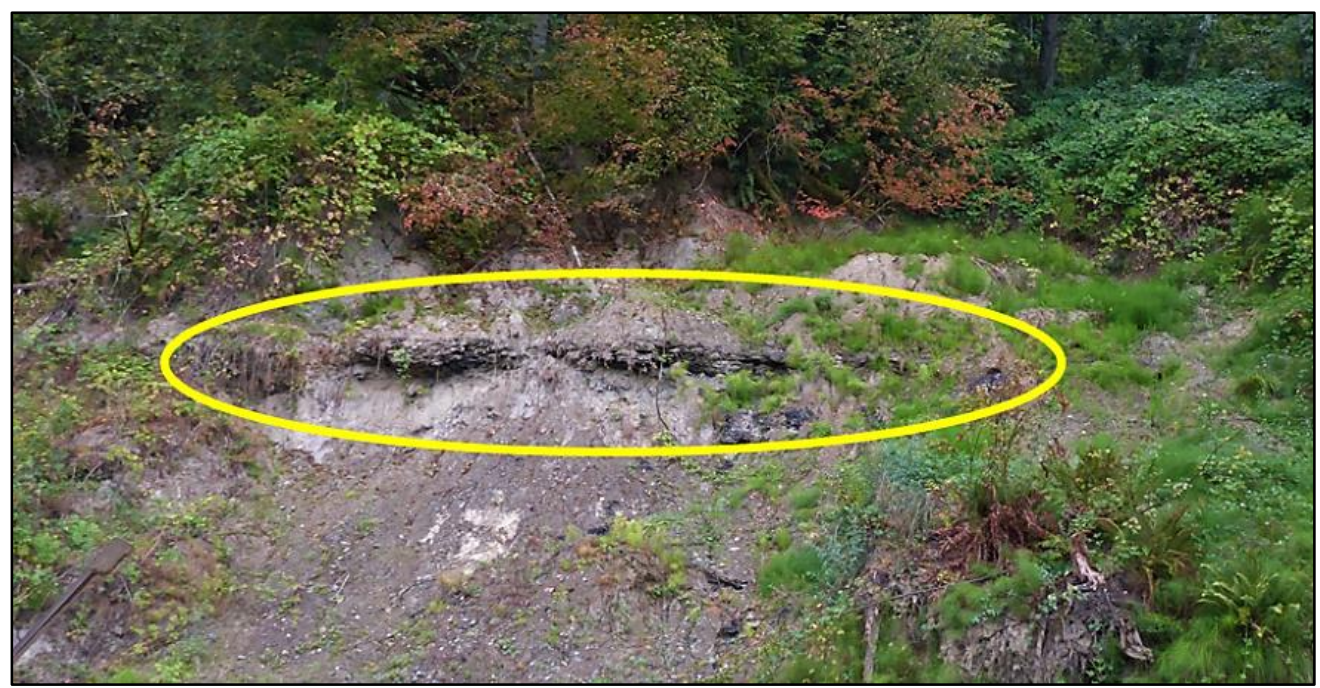

Figure 10. Example of a sample site with a log buried in sediment and exposed along a road cut (yellow oval). This log had a pre-last glacial maximum age, but was located in a post-last glacial maximum landslide deposit, indicating it had been remobilized. 


\subsection{Roughness Analysis}

I define surface roughness as the average standard deviation of slope within a landslide deposit. The performance of this metric as an indicator of time was evaluated using absolute ages and relative ages for those that shared cross-cutting relationships with an adjacent landslide. For consistency with previous studies (LaHusen et al., 2016; Booth et al., 2017) I calculate roughness as follows: (1) Measure slope in degrees of each pixel from the lidar DEM based on the eight nearest neighboring pixels, creating a slope raster. (2) Calculate a local standard deviation (roughness) of that raster in a moving window using the Focal Statistics tool in ArcGIS. This defines the local roughness at each pixel in the DEM. (3) Remove gullies and roads from the landslide deposit polygons. (4) Average the local roughness of all pixels using the Zonal Statistics tool in ArcGIS (Figure 11).

Three different window sizes of 3,15, and $30 \mathrm{~m}$ were used to make three roughness raster maps. I used the roughness raster map for each of the three window sizes as the input raster to run a statistical analysis where I found the mean roughness of each landslide deposit polygon (step 4). These averages were compared against cross-cutting relationships to see which window size was the best at capturing relative ages. I determined cross cutting relationships using a lidar shaded DEM with the knowledge that a younger deposit will cross cut an older deposit. For the subset of directly dated landslides, I plotted roughness against known landslide absolute age to develop the age-roughness model. 


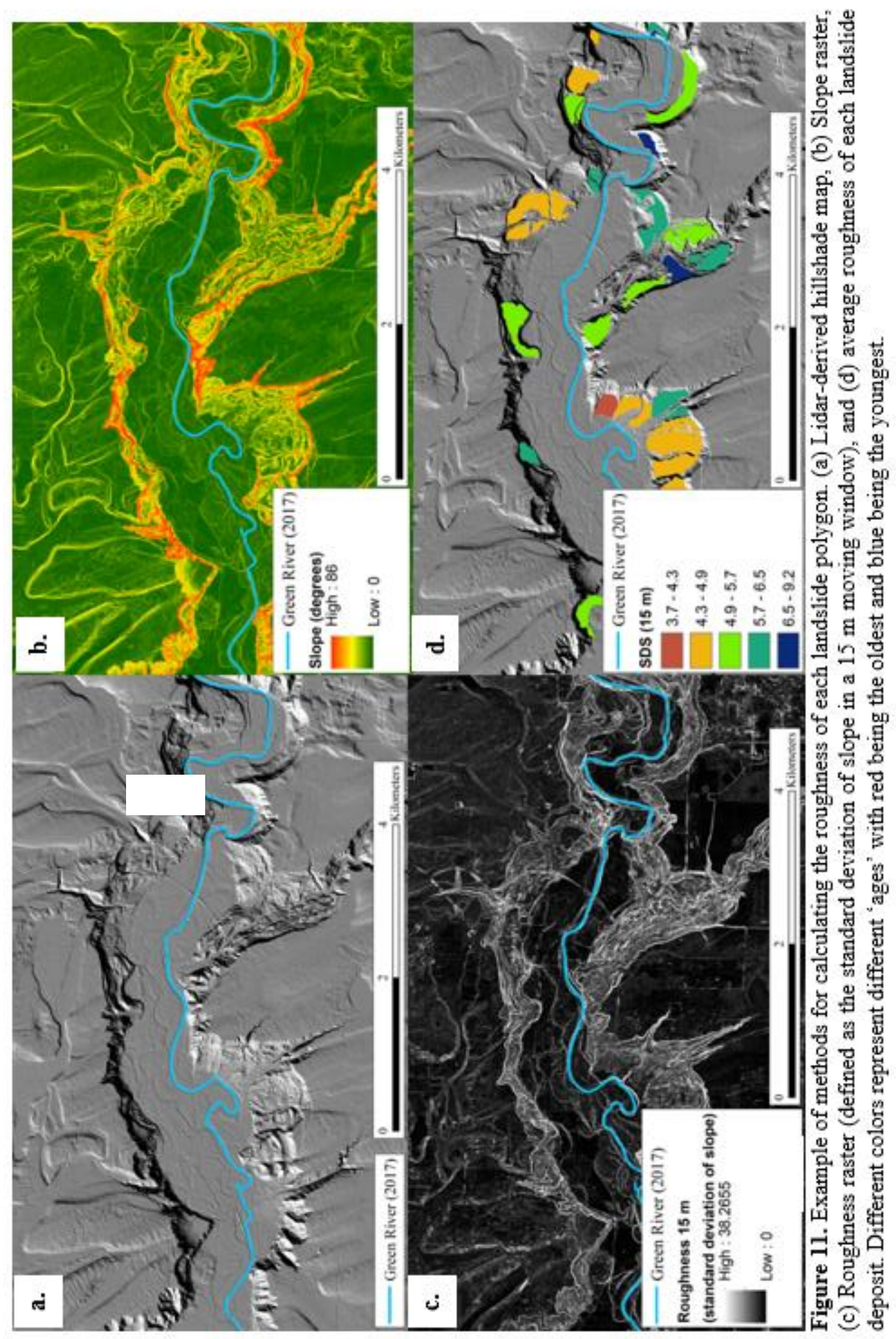




\subsection{Spatial Patterns of Landslides}

\section{Results}

A total of 61 mapped landslides are located along a 29 (river) kilometer stretch of the Green River with areas ranging from 2,300 $\mathrm{m}^{2}$ to $930,000 \mathrm{~m}^{2}$ (Figures 12 and 13). I found 20 landslides located on the north side and 41 landslides on the south side. Along this $29 \mathrm{~km}$ reach the average gradient of the river changes. The gentler lower section, from river kilometer 1 to 21 (valley kilometer 1 to 16 ), has an average gradient of $0.34 \%$. The knickzone, from river kilometer 21 to 29 (valley kilometer 16 to 24), has an average gradient of $0.64 \%$, making it almost twice as steep as the lower section (Figure 14). The knickzone extends slightly further upstream, as mapped by Jonathan Perkins (personal communication, 2017), but since there are very few landslides above the knickzone, I focus on the reach of the Green River downstream of the knickzone (Figure 15).

Local relief ranges from approximately 30 to $130 \mathrm{~m}$ on the north side and approximately 25 to $185 \mathrm{~m}$ on the south side (Figure 16). When comparing local relief to landslides there appears to be an average threshold local relief of approximately 50 to 60 $\mathrm{m}$ where below $50 \mathrm{~m}$ no landsides occur. On the south side of the valley multiple landslides per river kilometer start to occur once a local relief of about $100 \mathrm{~m}$ is reached. However, from valley kilometer 18 to 21 there are multiple landslides (2 or more) where the local relief is as low as $55 \mathrm{~m}$.

Valley bottom width ranges from 30 to $1100 \mathrm{~m}$ (Figure 17). The valley is widest from 1 to 15 valley kilometers where widths range from 400 to $1100 \mathrm{~m}$. At valley kilometer 16 (river kilometer 21), the approximate location of the lower end of the knickzone, valley bottom width decreases sharply from 400 to $80 \mathrm{~m}$ (Figure 17). In the lower section of the 
Green River, from 1 to 16 valley kilometers, the average valley width is $840 \mathrm{~m}$ while in the knickzone, from 16 to 24 valley kilometers, the average valley width is $55 \mathrm{~m}$.

The spatial pattern of landslides is not uniform along the valley, and instead varies systematically with local relief and valley width. On the south side of the valley, where the vast majority of landslides are mapped, are three large landslide complexes. The north side of the valley has no large landslide complexes. These landslide complexes are located at valley kilometers 7 to 10 with seven landslides, 10 to 13 with six landslides, and 18 to 20 with ten landslides. Between valley kilometer 7 and 10 the relief ranges from 105 to 122 $\mathrm{m}$, and the valley bottom width ranges from 777 to $1104 \mathrm{~m}$, the widest part of the valley within the study area. Between valley kilometer 10 and 13 the relief is also high and ranges from 111 to $122 \mathrm{~m}$, and the valley bottom width is slightly smaller, ranging from 500 to $906 \mathrm{~m}$. These two landslide complexes are mapped as being underlain by Osceola Mudflow deposits which overlie glacial deposits. Between valley kilometer 18 to 20 the relief is more variable and ranges from 55 to $184 \mathrm{~m}$, while the valley bottom width is dramatically smaller, ranging from 49 to $69 \mathrm{~m}$. The highest measured local relief of $184 \mathrm{~m}$ on the south side of the valley also has one of the smallest valley bottom widths of $69 \mathrm{~m}$. This upstream landslide complex is within the knickzone and is mapped as being underlain by glacial deposits that overlie bedrock. 


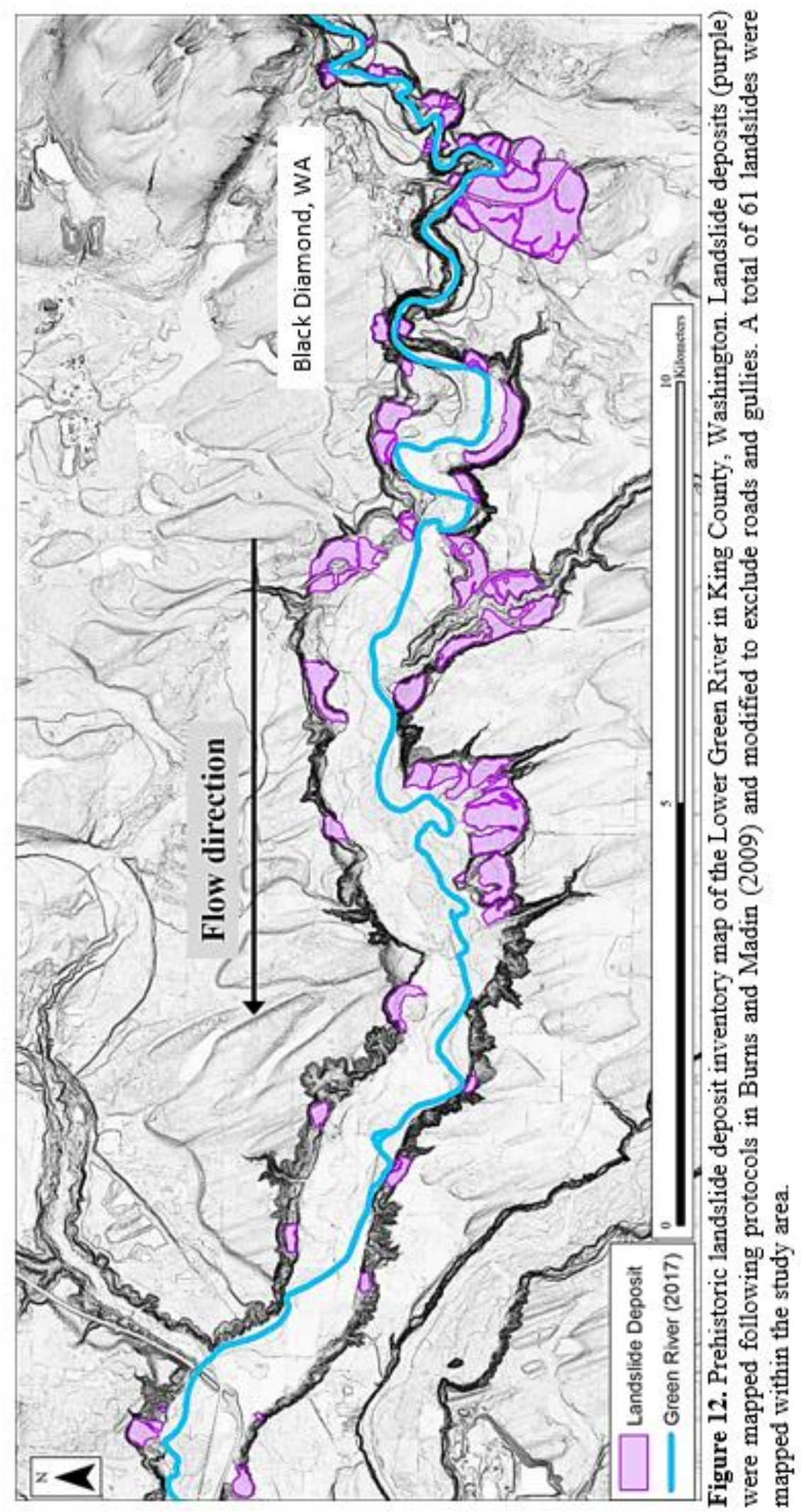




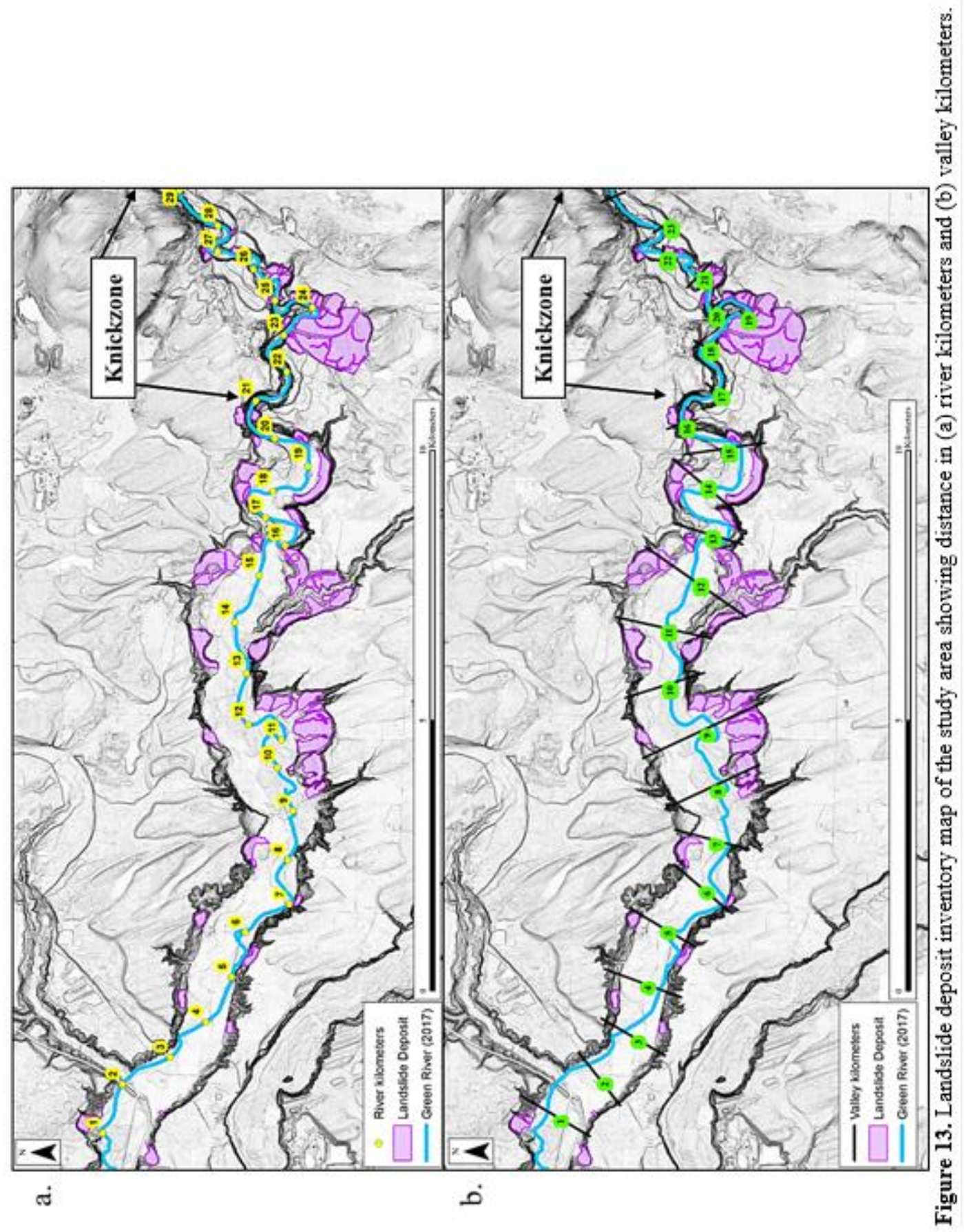




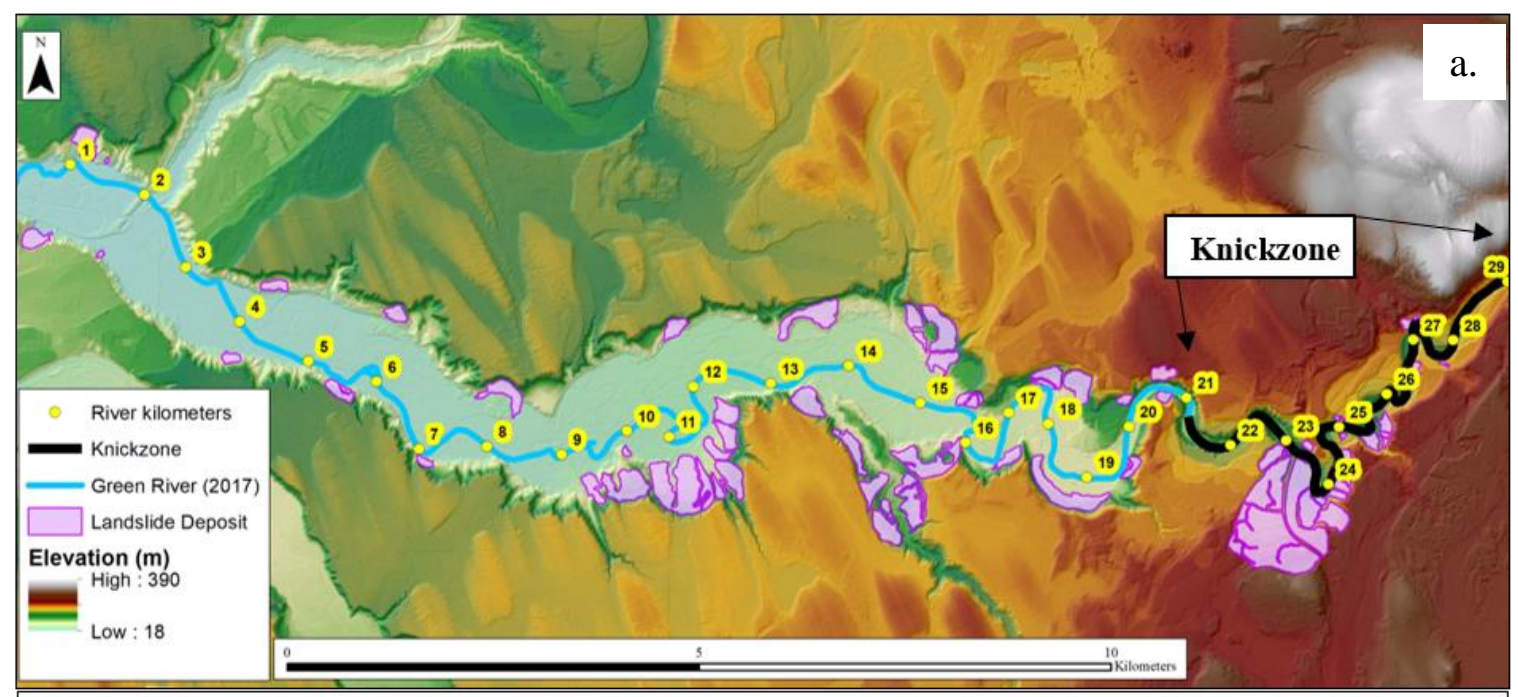

Elevation Profile of the Lower Green River

b.

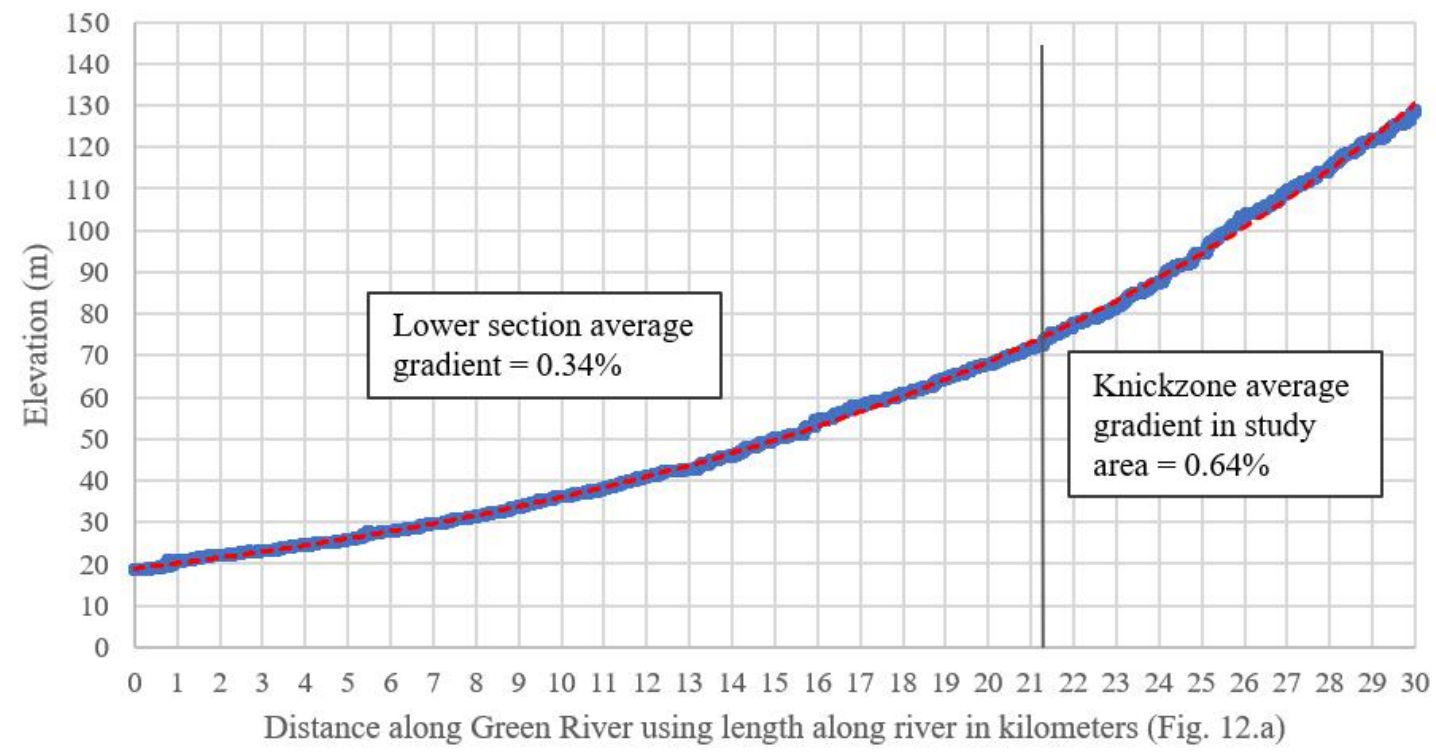

Figure 14. (a) Elevation map showing the elevation range along the Lower Green River Valley. The location of the knickzone (black line) is shown on the map. (b) The Green River longitudinal profile graph showing the lower section and knickzone and their average gradients. The red dashed line is an exponential fit. 


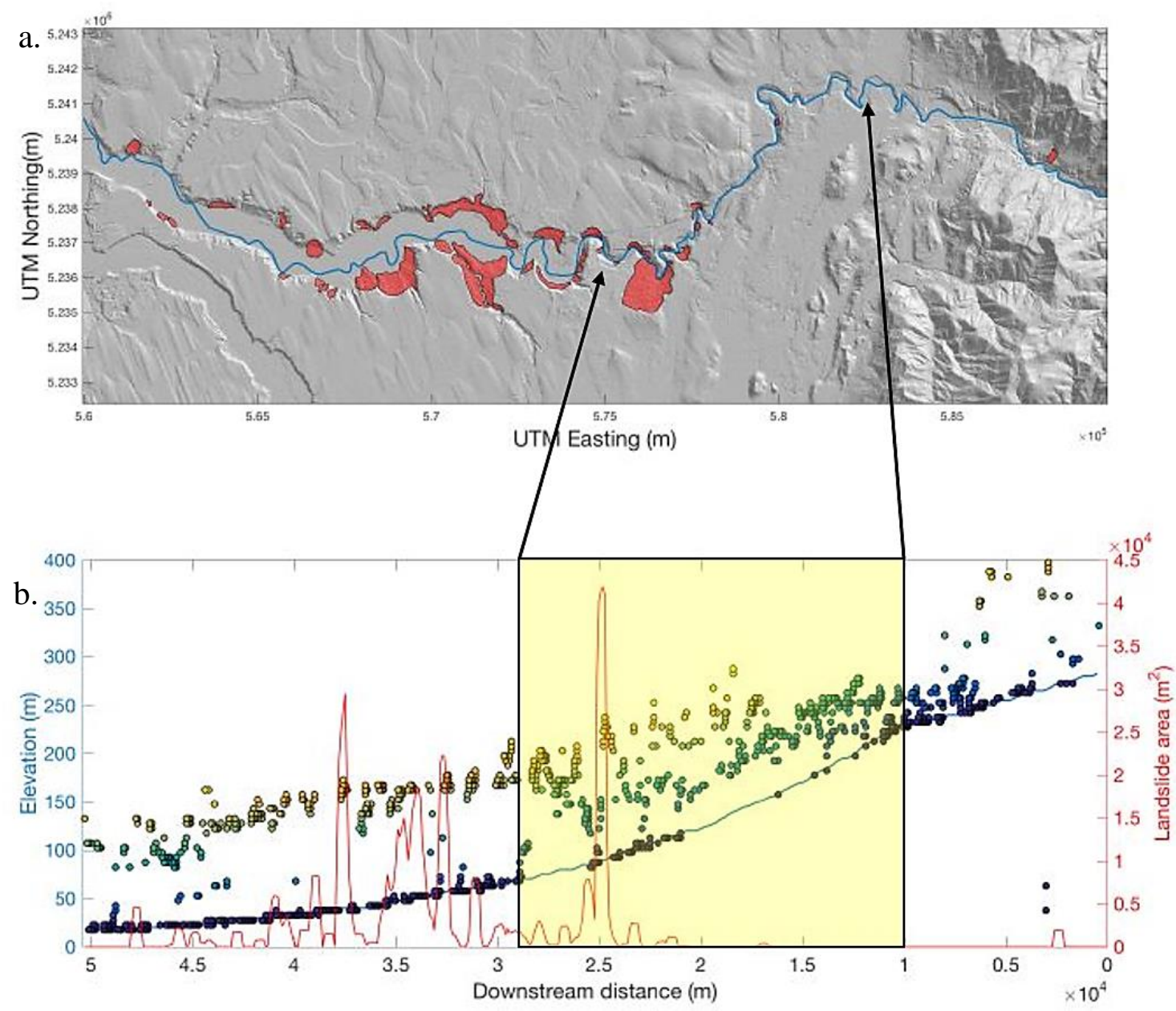

Figure 15. (a) Hillshade map with landslide polygons mapped by Perkins (personal communication, 2017) and (b) Longitudinal profile of the Green River (blue line), terrace elevations (dots), and landslide area (red line) vs. downstream distance. The majority of landslides are at or downriver of the knickzone (yellow box in bottom plot). (Modified from Jonathan Perkins, 2017). 
a.
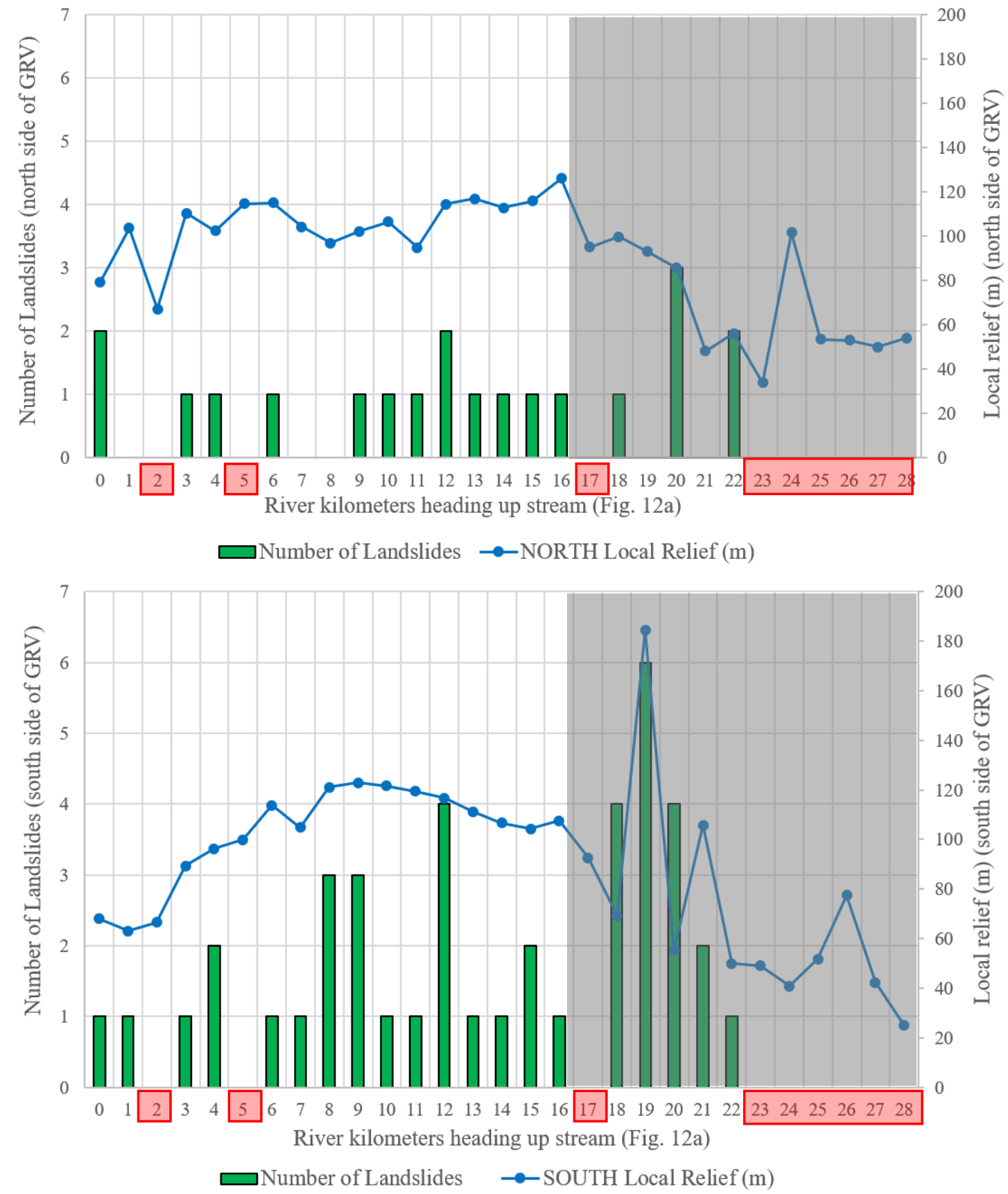

Figure 16. Number of landslides (green bars) and local relief (blue lines) vs. upstream distance on the (a) north side and (b) south side of the Green River Valley. The grey box shows the location of the knickzone and the red boxes signify where no landslides were mapped. 


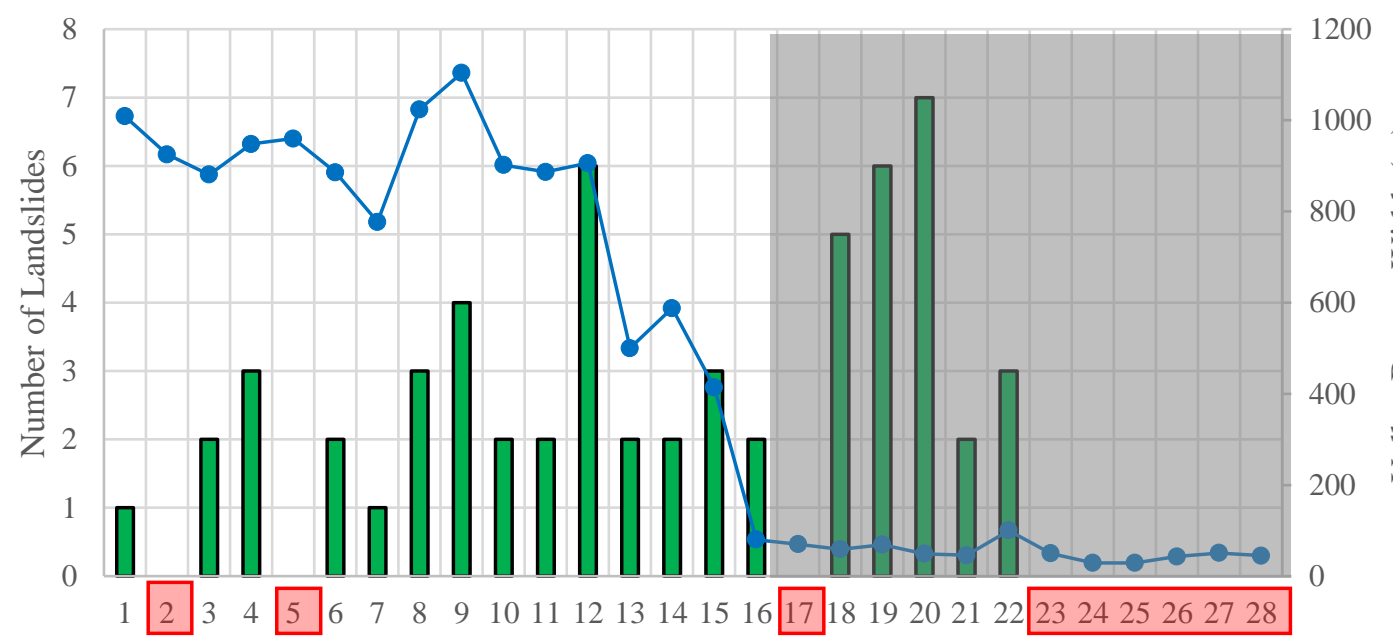

1200

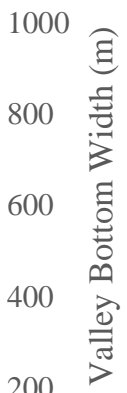

Distance in kilometers heading up stream (measured within the river valley)

$\square$ Number of Landslides $\longrightarrow$-Valley bottom width (m)

Figure 17. Number of landslides (green bars) and valley bottom width (blue line) vs. distance upstream. The grey box shows the location of the knickzone and the red boxes signify at what kilometer in the Green River Valley no landslides were mapped.

\subsection{Roughness and Evaluation Against Relative Ages}

All three window sizes had different numerical ranges for their average standard deviation of slope (SDS) in the landslide deposit. The $3 \mathrm{~m}$ window size had an average SDS range of $1.6^{\circ}$ to $3.3^{\circ}, 15 \mathrm{~m}$ a range of $3.7^{\circ}$ to $9.2^{\circ}$, and $30 \mathrm{~m}$ a range of $4.9^{\circ}$ to $12.0^{\circ}$ (Figure 18). Standard deviation increased with window size because that statistical measure tends to increase with sample size.

To assess how well roughness measured in each of the three window sizes predicted relative landslide age, it was compared to cross cutting relationships between landslide deposits. Of the 61 landslide deposits, 30 shared cross cutting boundries (Figure 19). The $3 \mathrm{~m}$ window based roughness had $25(83.3 \%)$ correct relative ages, the $15 \mathrm{~m}$ had 24 (80.0\%), and the $30 \mathrm{~m}$ had $23(76.6 \%)$. 
Although the differences among the three window sizes were only $6 \%$, the $3 \mathrm{~m}$ window size corretly matched two landslide pairs that the $15 \mathrm{~m}$ and $30 \mathrm{~m}$ window sizes did not (Figure 20). These two landslide pairs have very different surface morphologies, likely caused by different failure styles, with one pair having a much higher surface rouhness than the other. There were no relative age relationships that the $15 \mathrm{~m}$ or $30 \mathrm{~m}$ window sizes correctly identified independently from the other window sizes, but there was one landslide pair that both the 15 and $30 \mathrm{~m}$ window sizes correctly categorized that the $3 \mathrm{~m}$ window size did not (Figure 21). The surface morphologies of this landslide pair are visually very similar. 


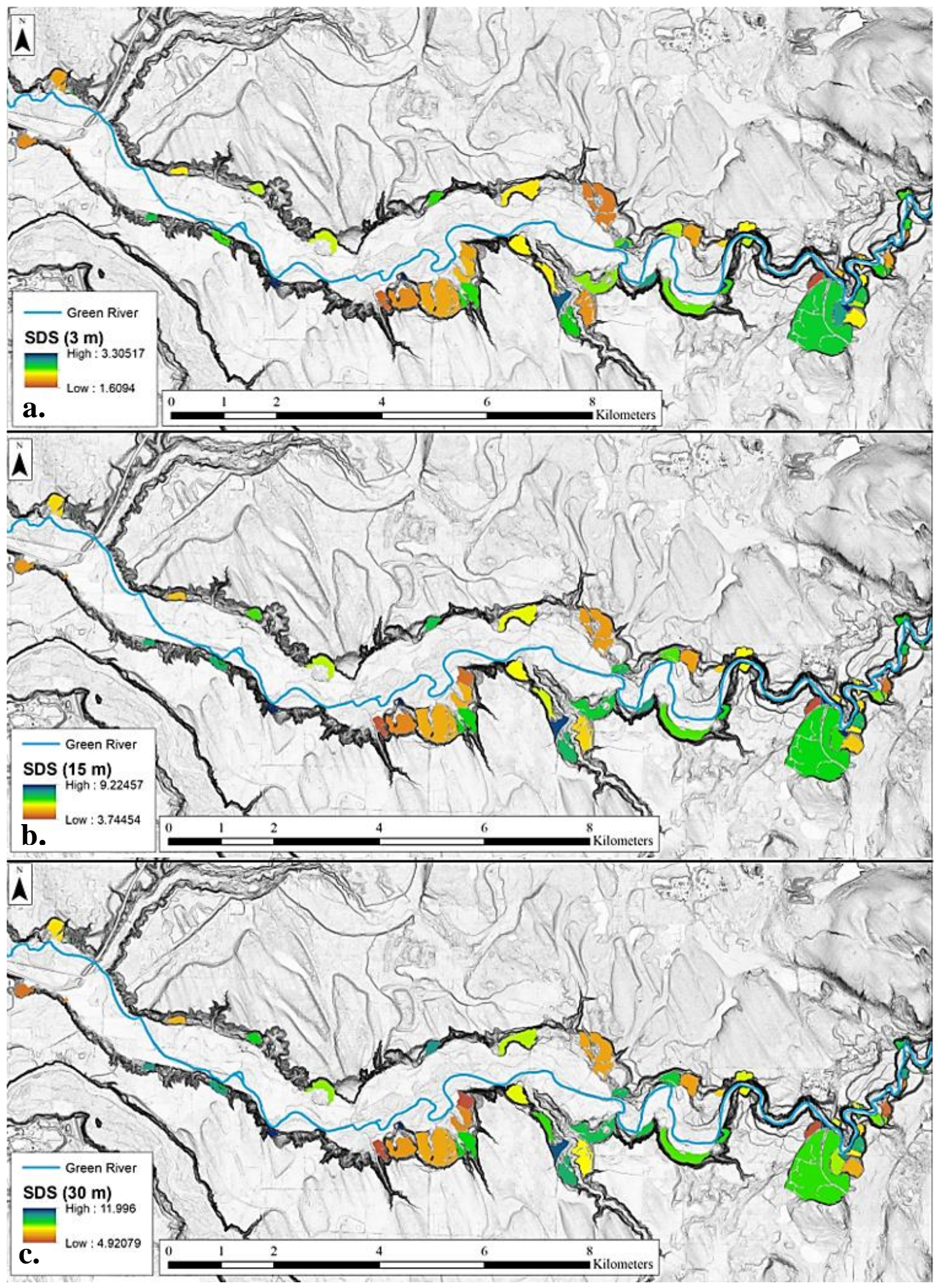

Figure 18. Average roughness, measured as the standard deviation of slope in a moving window, of each landslide deposit in (a) $3 \mathrm{~m}$, (b) $15 \mathrm{~m}$, and (c) $30 \mathrm{~m}$ window sizes. 


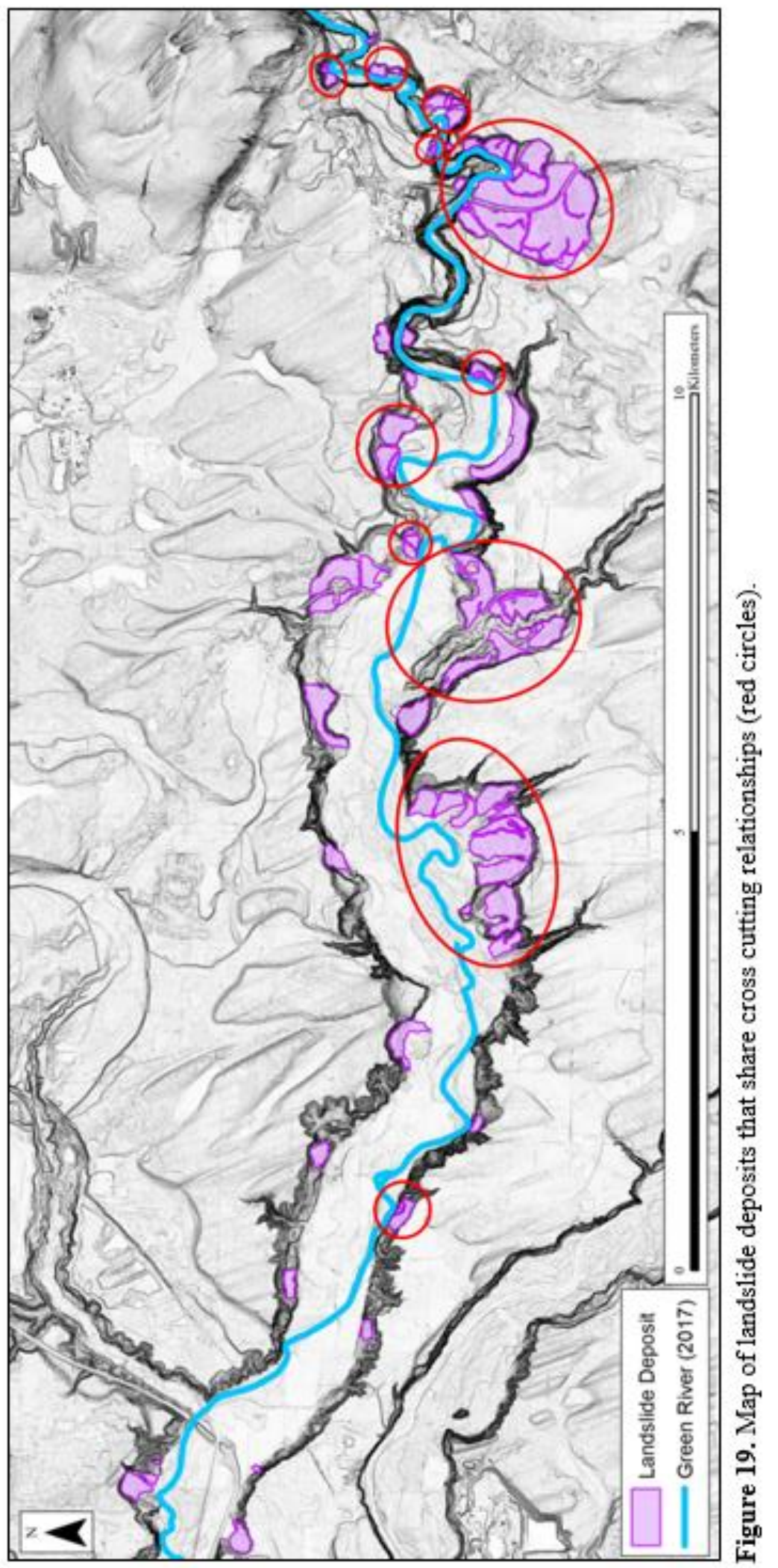




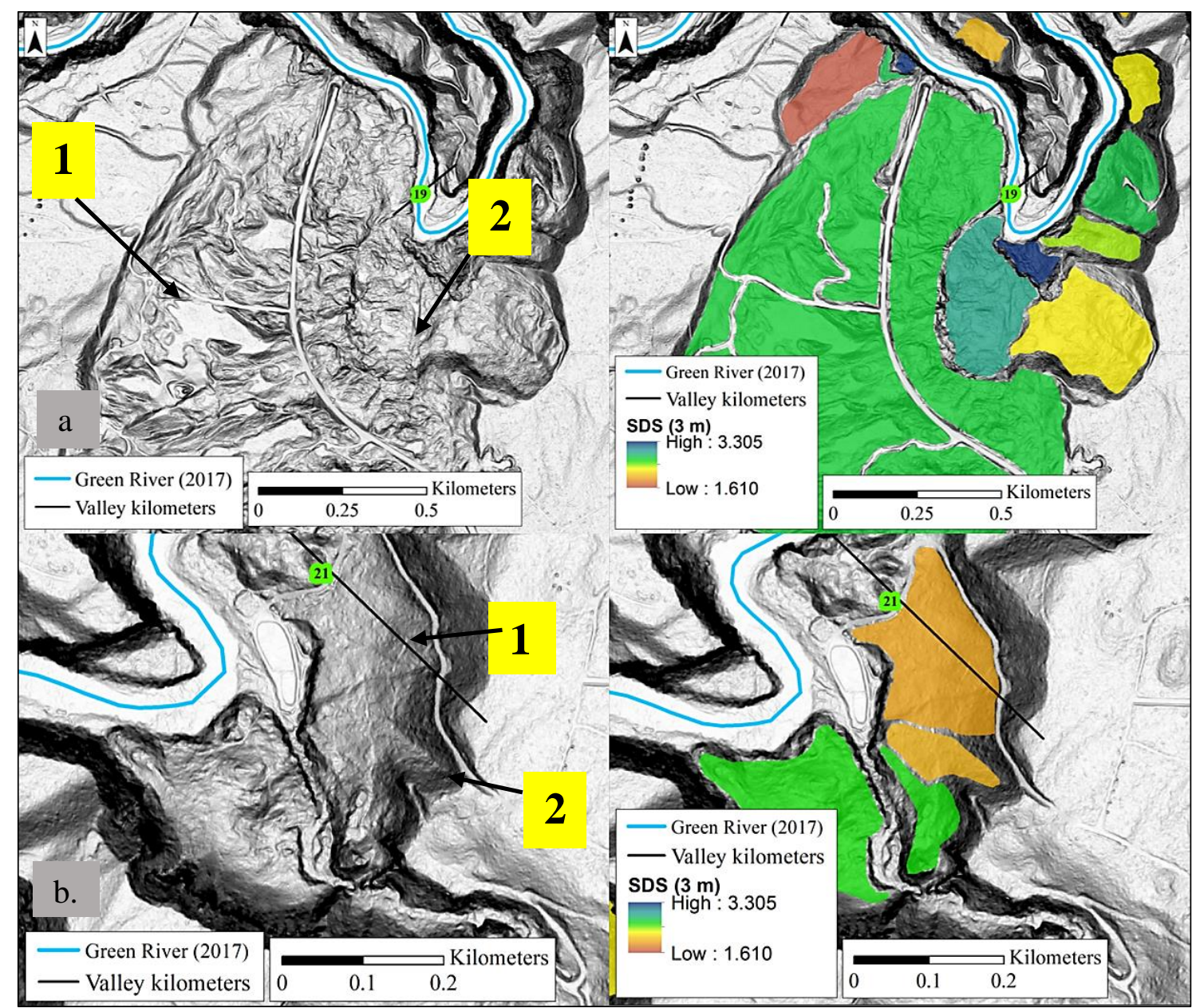

Figure 20. Detailed maps of the two landslide relative age pairs ( $a$ and $b$ ) that only the $3 \mathrm{~m}$ window size correctly identified.

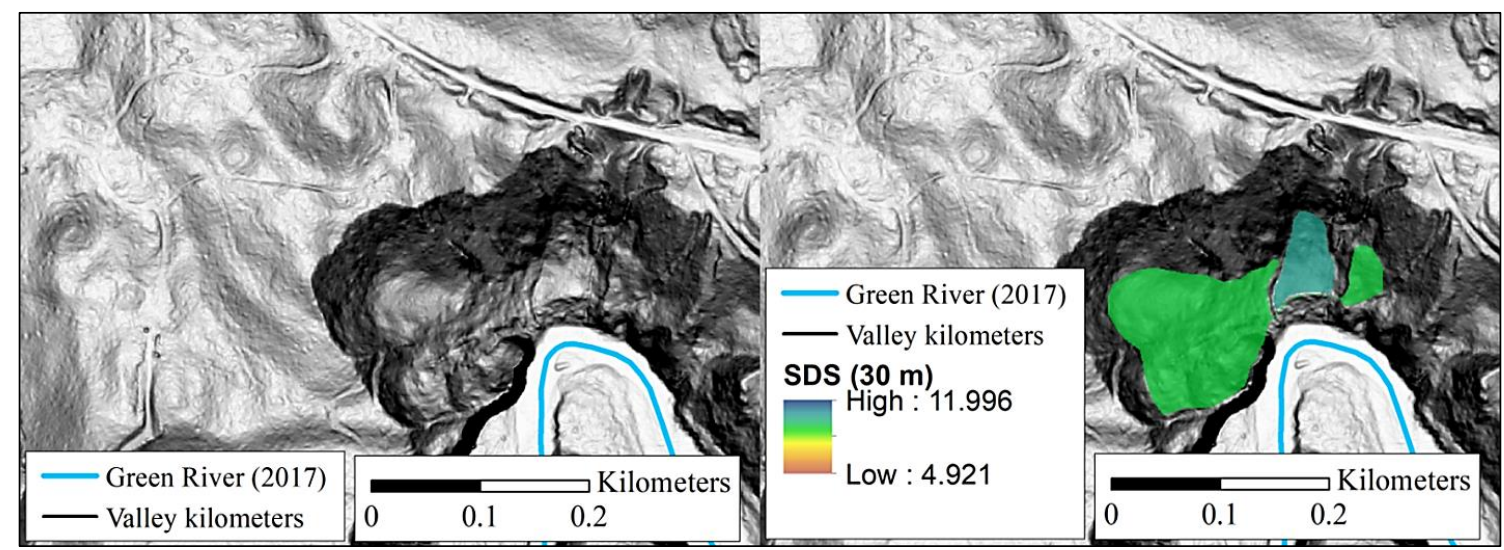

Figure 21. Detail map of the one landslide relative age pair that the $30 \mathrm{~m}$ (shown here) and $15 \mathrm{~m}$ window sizes correctly identified, but the $3 \mathrm{~m}$ window size did not. 


\subsection{Radiocarbon Dating}

An extensive field campaign from September 2016 to January 2018 resulted in 12 samples, 7 of which were radiocarbon dated. The five samples not chosen for radiocarbon dating were either duplicates, too degraded, or were determined by post-field lidar interpretation to be buried by small stream bank failures and therefore not representative of the age of the mapped landslide deposit. The 7 dated samples are abbreviated 1) OW2, 2) $\mathrm{TB} 3$, 3) GVR01, 4) FG1, 5) FG2, 6) FG3, and 7) BD1 and are located within a 15 (valley) $\mathrm{km}$ stretch of the Green River (Figure 22).

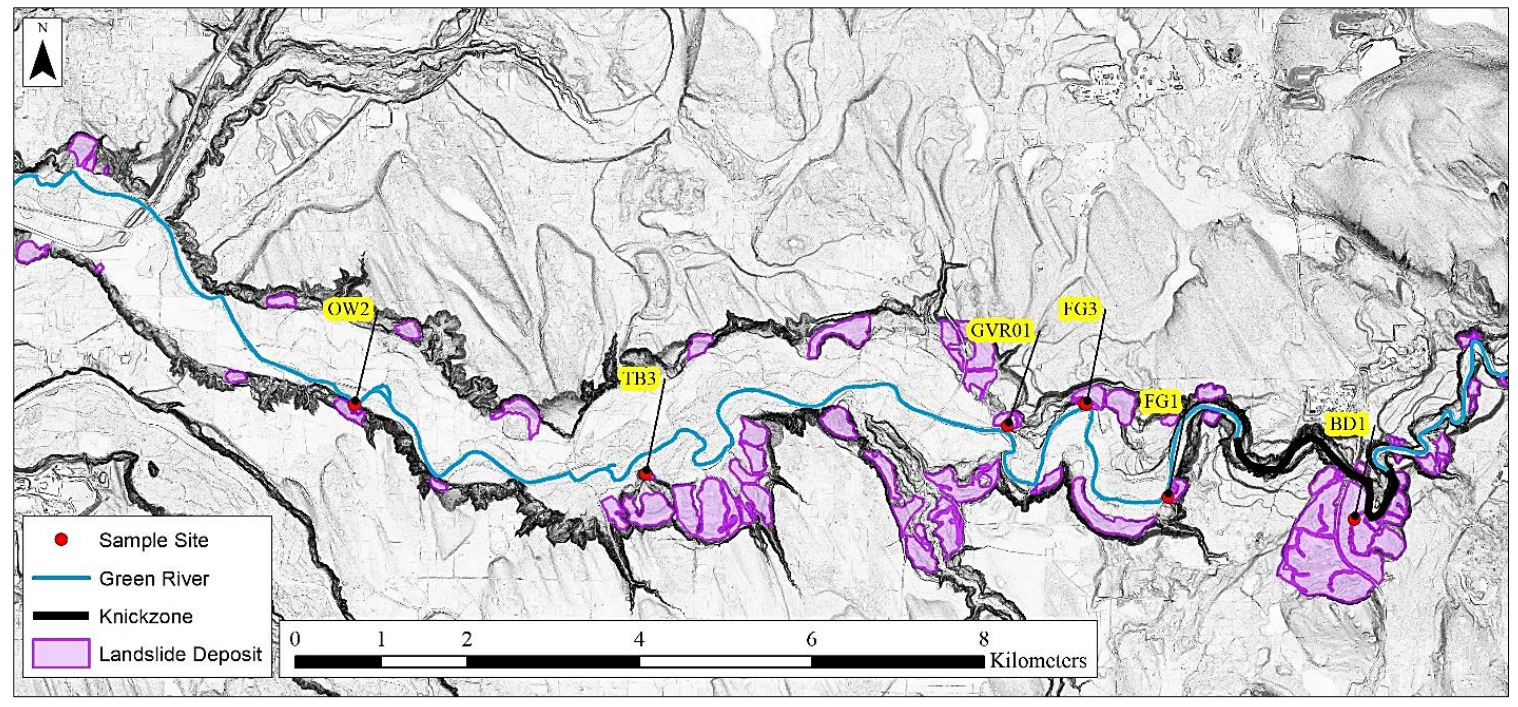

Figure 22. Map showing the sample site locations with their sample ID names. Only one sample was collected within the knickzone boundary (black line). (Note: FG2 is not shown on the map above but was found in the same deposit as FG3)

Although all the samples were woody debris entrained in landslide deposits, their site conditions varied. Sample OW2, the sample located farthest downstream, came from the outer growth rings of a large log at modern river level from a relatively loose deposit. Sample TB3 came from a branch in a loose deposit above river level. Sample GVR01 came from the outer growth rings of a burned log exposed in a road cut along the river. Sample 
FG1 came from a log in a relatively loose deposit just above modern river level. Samples FG2 and FG3 came from some branches a few meters above modern river level in the same indurated deposit. Sample BD1, located near the upstream boundary of the study site, came from a branch under a large boulder exposed by gully incision. Of the 7 samples, GVR01 and FG2 had no measurable modern carbon and were dated as carbon dead $(>45,000 \mathrm{cal}$. BP). Sample FG3 also was close to carbon dead with a calibrated age of 42591-41494 cal. BP. The remaining 4 samples, OW2, TB3, FG1, and BD1 had radiocarbon ages that were calibrated and determined to be younger than 492 cal. BP (Figure 23) (Table 1). The 4 youngest samples are all located on the south side of the GRV, while the carbon dead samples are located on the north side (Figure 22 and 24).

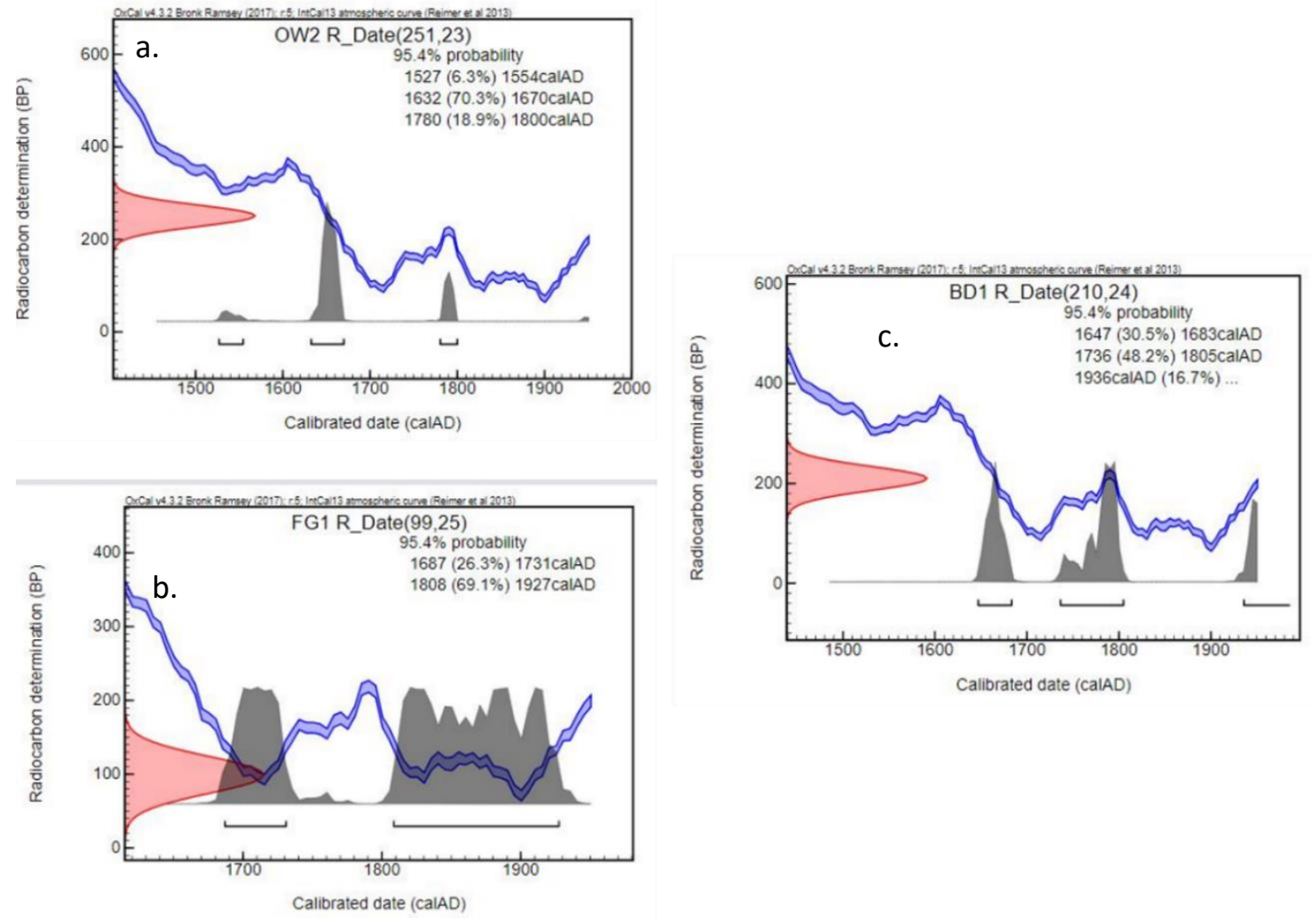

Figure 23. Radiocarbon age vs. calibrated ages in calendar years (cal. AD) for the four youngest samples, using The University of Oxford's Oxcal radiocarbon calibration program. a) OW2, b) FG1 c) BD1 
Table 1. Samples with their radiocarbon ages and calibrated ages in both cal. BP and calendar years (cal AD). All the samples were wood found within the landslide deposit.

\begin{tabular}{crrrr}
\hline Sample ID & $\begin{array}{c}\text { Radiocarbon } \\
\text { age (yrs) } \\
\text { error })\end{array}$ & $\begin{array}{c}\text { Yrs cal. BP } \\
\text { (1 } \boldsymbol{\sigma} \text { error) }\end{array}$ & $\begin{array}{c}\text { Age Range } \\
\text { cal AD }\end{array}$ & Location (longitude; latitude) \\
\hline OW2 & $251 \pm 23$ & $219-492$ & $1527-1800$ & $-122.144267 ; 47.282581$ \\
\hline TB3 & $(-) 440 \pm 30$ & 0 & modern & $-122.099559 ; 47.275953$ \\
\hline GVR01 & NDFB* & $>45,000$ & unknown & $-122.044083 ; 47.281511$ \\
\hline FG2 & NDFB* & $>45,000$ & unknown & $-122.032281 ; 47.283898$ \\
\hline FG3 & $42545 \pm 369$ & $41494-$ & & \\
\hline FG1 & 92591 & $* 44610-43513$ & $-122.032019 ; 47.283888$ \\
\hline BD1 & $210 \pm 24$ & $92-332$ & $1687-1927$ & $-122.019316 ; 47.274350$ \\
\hline
\end{tabular}

$*$ NDFB $=$ not distinguishable from background 


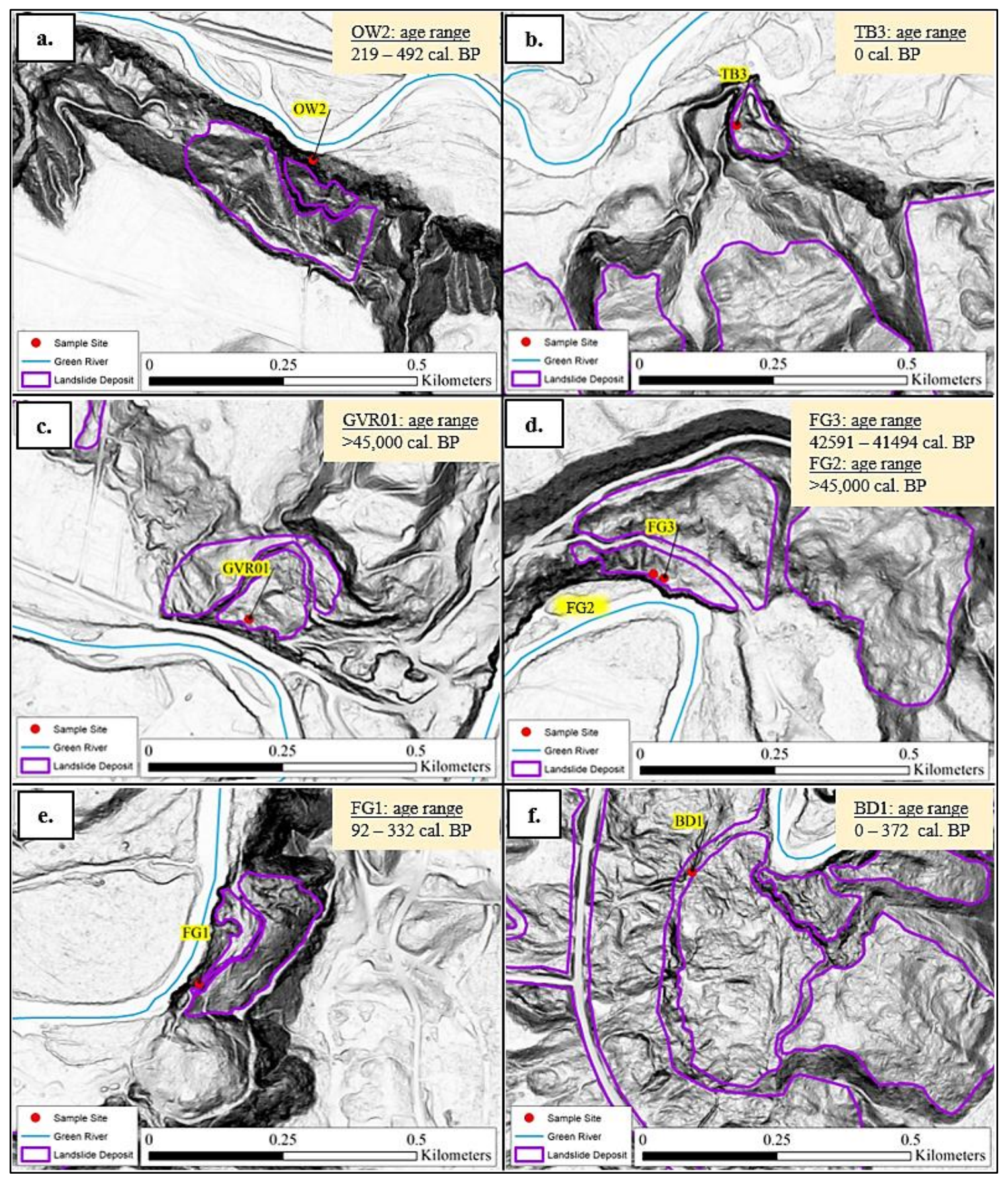

Figure 24. Maps showing the locations of the seven dated samples (a. OW2, b. TB3, c. GVR01, d. FG3 \& FG2, e. FG1, and f. BD1) with their calibrated ages (cal. BP). 


\subsection{Age Roughness Models}

The midpoint of each absolute age range from the four youngest landslide deposits (BD1, FG1, OW2, and TB3) were plotted against their roughness values and fit with an exponential decay function to develop an age-roughness model for each window size (Figures 25). The older ages were not used because they are not indicative of landslide age. A maximum age of 12,000 cal. BP was assumed for the smoothest landslide in the inventory to provide a likely maximum age constraint (Figure 26). This age constraint was based on the work done in the NFSR where a terrace located 4 meters above modern river level was dated at 12,000 cal. BP, indicating that Puget Lowland rivers incised rapidly and generated topographic relief following deglaciation (LaHusen et al., 2016). This is also a reasonable estimate for the GRV due to the retreat of the ice sheet 16,420 cal. BP with most of the isostatic rebound happening in the first few thousand years following retreat (Porter and Swanson, 1998). The most recent landslide TB3 is dated as 0 cal. BP and the average SDS from the landslide deposit it came from is used as the minimum age constraint. Its roughness value is not the greatest $\left(3.3^{\circ}\right.$ at $3 \mathrm{~m}$ window size $)$, but it is used as the minimum roughness.

An exponential function fit each data set well with R-squared values of 0.83 for data based on the $3 \mathrm{~m}$ window, 0.81 for the $15 \mathrm{~m}$, and 0.73 for the $30 \mathrm{~m}$. They show a rapid decrease in roughness with increasing age for young landslides less than about 1,000 cal. $\mathrm{BP}$, followed by a gradual decrease in roughness with age for older landslides. In addition to the three age-roughness models for the GRV, I applied LaHusen et al.'s (2016) ageroughness model from the North Fork Stillaguamish River (Table 2). The new GRV data predicted slightly younger ages for a given roughness, but were also statistically consistent 
with the North Fork Stillaguamish River age-roughness model. By comparing the predicted ages of each model to the known ages of the dated landslides, it is clear that each of the age roughness models predicts landslide ages at least to the correct order of magnitude. For example, the historic landslides consistently have the highest roughness values, and the landslides dating to several hundred years before present consistently have moderate roughness values. The $3 \mathrm{~m}$ window size has the closest age match to Sample's TB3 (youngest of the four youngest landslides) and BD1, while the GRV model's $15 \mathrm{~m}$ window has the closest match with OW2 (oldest of the four youngest landslides) and LaHusen's (2016) model's 15 m window has the closest match with FG1 (Table 2). 


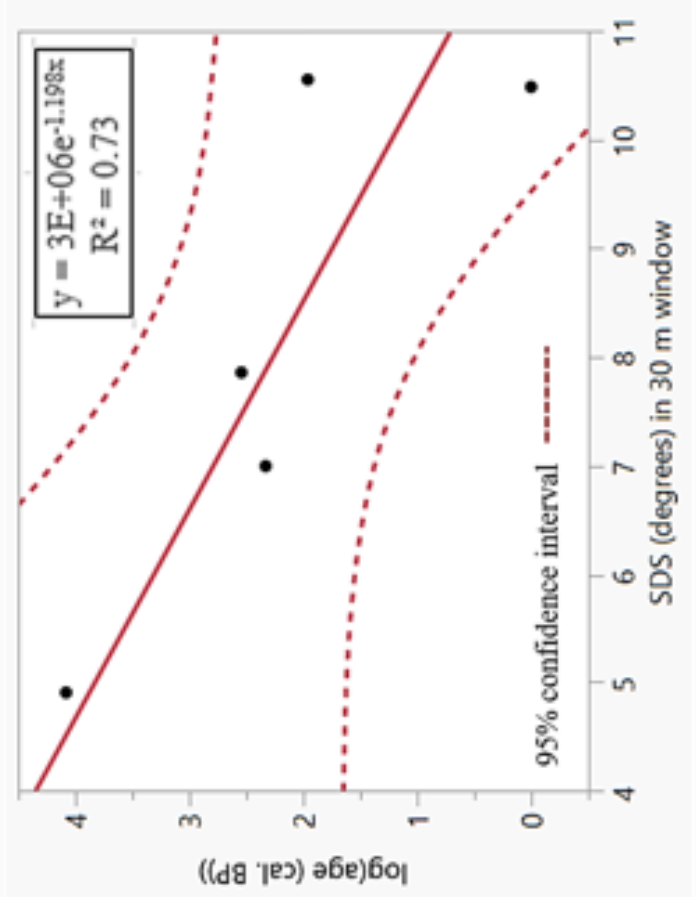

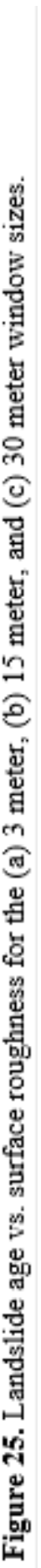




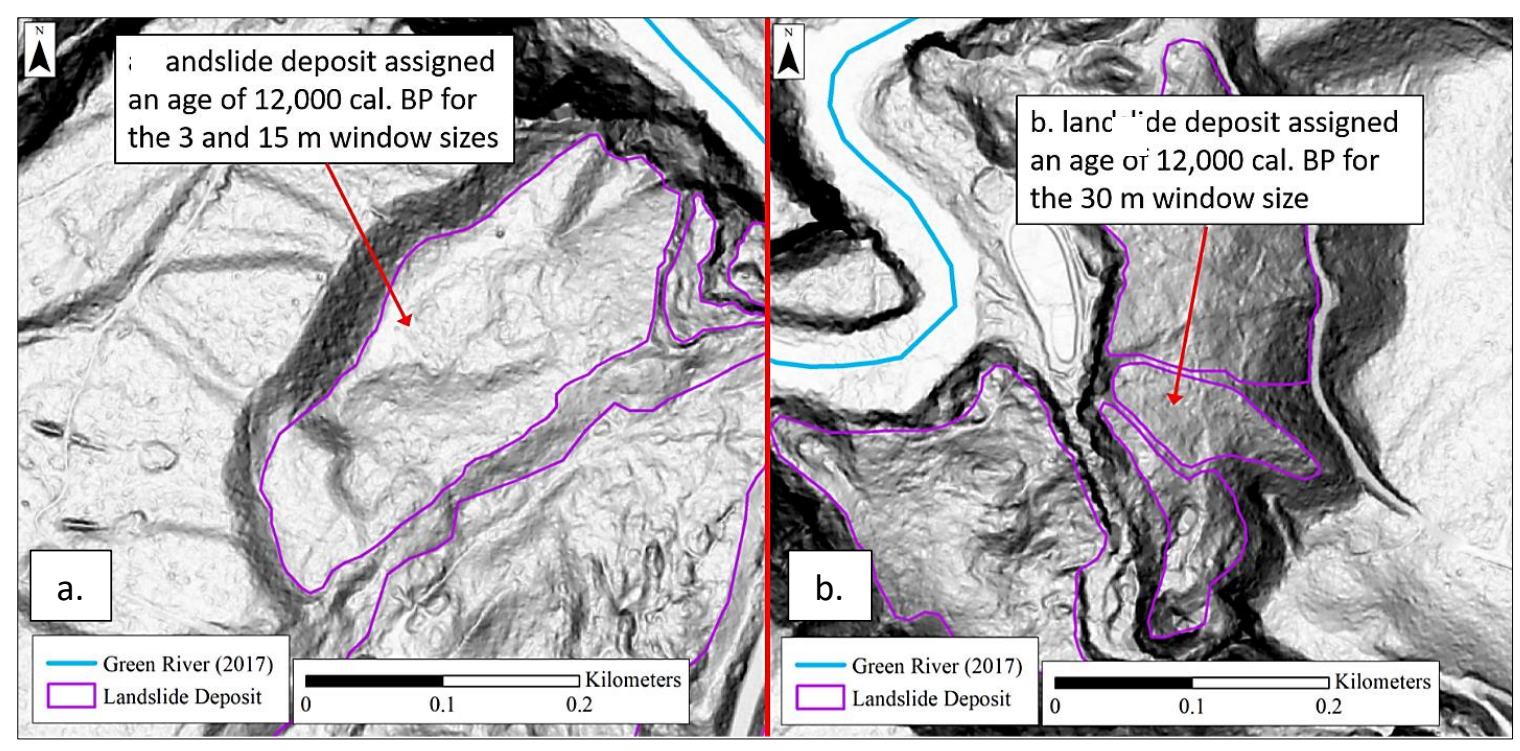

Figure 26. (a) Landslide deposit used to assign the maximum age constraint of 12,000 cal. BP to the $3 \mathrm{~m}$ and $15 \mathrm{~m}$ window sizes, and (b) the landslide deposit used for the $30 \mathrm{~m}$ window size.

Table 2. Absolute ages and calculated ages predicted by each age-roughness model for each window size of the four directly dated landslides.

\begin{tabular}{ccccccc}
\hline $\begin{array}{c}\text { Landslide } \\
\text { Id }\end{array}$ & $\begin{array}{c}\text { Sample } \\
\text { Name }\end{array}$ & $\begin{array}{c}\text { Age } \\
\text { cal. BP }\end{array}$ & $\begin{array}{c}\text { Calculated } \\
\text { cal. BP (3 m) }\end{array}$ & $\begin{array}{c}\text { Calculated } \\
\text { cal. BP (15 m) }\end{array}$ & $\begin{array}{c}\text { Calculated } \\
\text { cal. BP (30 } \\
\text { m) }\end{array}$ & $\begin{array}{c}\text { Calculated** } \\
\text { cal. BP (15 m) }\end{array}$ \\
\hline 8 & OW2 & 348 & 563 & 274 & 241 & 623 \\
\hline 14 & TB3 & 0 & 5 & 6 & 10 & 19 \\
\hline 35 & FG1 & 91 & 12 & 10 & 10 & 30 \\
\hline 43 & BD1 & 213 & 104 & 408 & 678 & 904 \\
\hline
\end{tabular}

**LaHusen et al., 2016 model.

All 61 landslide deposits had their absolute ages calculated for each window size using the age-roughness models defined above. Ages were then further sub-divided into four age-classification groups based on past climate patterns: (1) Prehistoric-Old $=>10,000$ cal. BP, (2) Prehistoric-Mature $=10,000$ to 5,000 cal. BP, (3) Prehistoric-Young $=5,000$ to $100 \mathrm{cal}$. BP, and (4) Historic-Active <100 cal. BP (Figure 27). The $3 \mathrm{~m}$ window size age-roughness model has one landslide in the Prehistoric-Old (>10,000 cal. BP) and three landslides in the Prehistoric-Mature age group (>10,000 to 5,000 cal. BP). A total of 49 
landslides are in the Prehistoric-Young (5000 to 100 cal. BP) age group, followed by eight landslides in the Historic-Active $(<100 \mathrm{cal}$. BP) age group. The thesis model's $15 \mathrm{~m}$ window size (LaHusen et al. 2016 model's landslide count will be in parenthesis) has one (four) landslide(s) in Prehistoric-Old, four (nine) landslides in Prehistoric-Mature, 49 (44) in Prehistoric-Young, and seven (four) in Historic-Active. The $30 \mathrm{~m}$ window size ageroughness model has zero landslides in the Prehistoric-Old age group, four landslides in Prehistoric-Old, 51 in Prehistoric-Young, and six in Historic-Active.

To search for possible trends within the Prehistoric-Young range of ages, this age group was further subdivided into 100 to $1000 \mathrm{cal}$. BP, 1000 to $2000 \mathrm{cal}$. PB, 2000 to 3000 cal. BP, 3000 to $4000 \mathrm{cal}$. BP, and 4000 to $5000 \mathrm{cal}$. BP (Figure 28). I also isolated landslides that cluster around 1000 cal. BP to identify landslides that may have been triggered by the most recent earthquake on the Seattle Fault. The ages within the $1000 \mathrm{cal}$. BP cluster are within +/- 100 years of 1000 (900 to 1100 cal. BP). Within the PrehistoricYoung group, all three window sizes show an increasing number of landslides from the oldest age subgroup to youngest age subgroup. All of age-roughness models predict that most of the landslides are in the 100 to $1000 \mathrm{cal}$. BP age group. The $30 \mathrm{~m}$ window has the most with 34 landslides, the $15 \mathrm{~m}$ thesis model and $3 \mathrm{~m}$ model have 27 landslides, and the $15 \mathrm{~m}$ LaHusen et al. (2016) model predicts 22 landslides (this model's highest). All window sizes' age-roughness models predict clusters of landslides around $1000 \mathrm{cal}$. BP, however, the $15 \mathrm{~m}$ thesis model has the most with seven landslides. This is followed by the $3 \mathrm{~m}$ and $30 \mathrm{~m}$ models with three landslides, and the LaHusen et al. (2016) model with two landslides. 


\section{$3 \mathrm{~m}$ window}

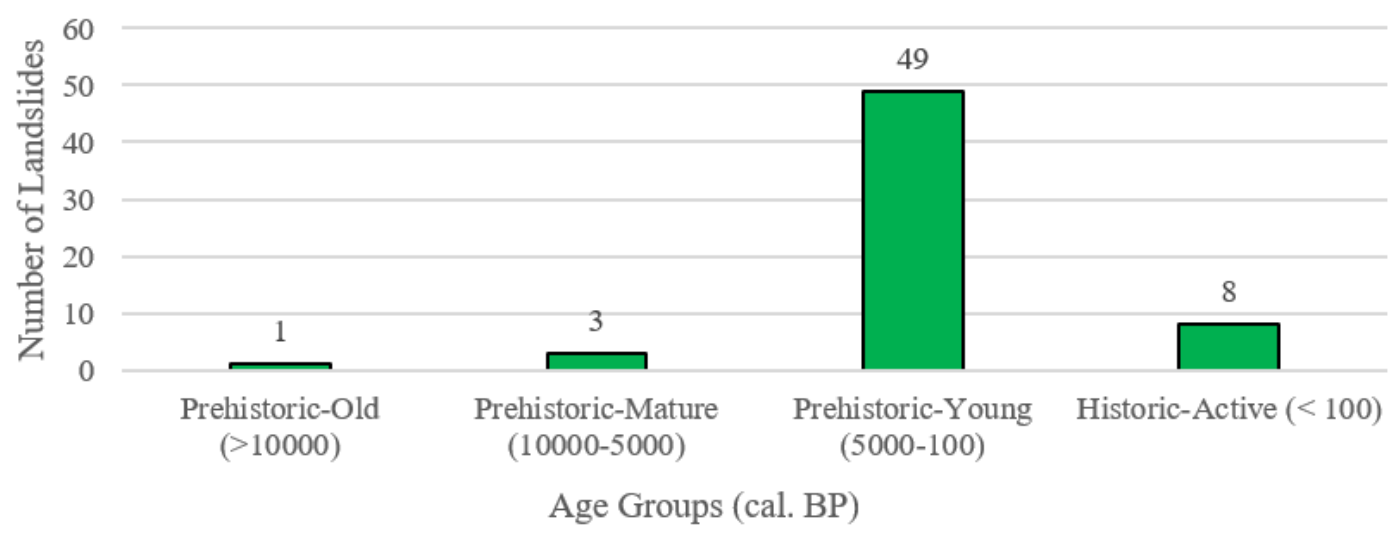

\section{$15 \mathrm{~m}$ window}

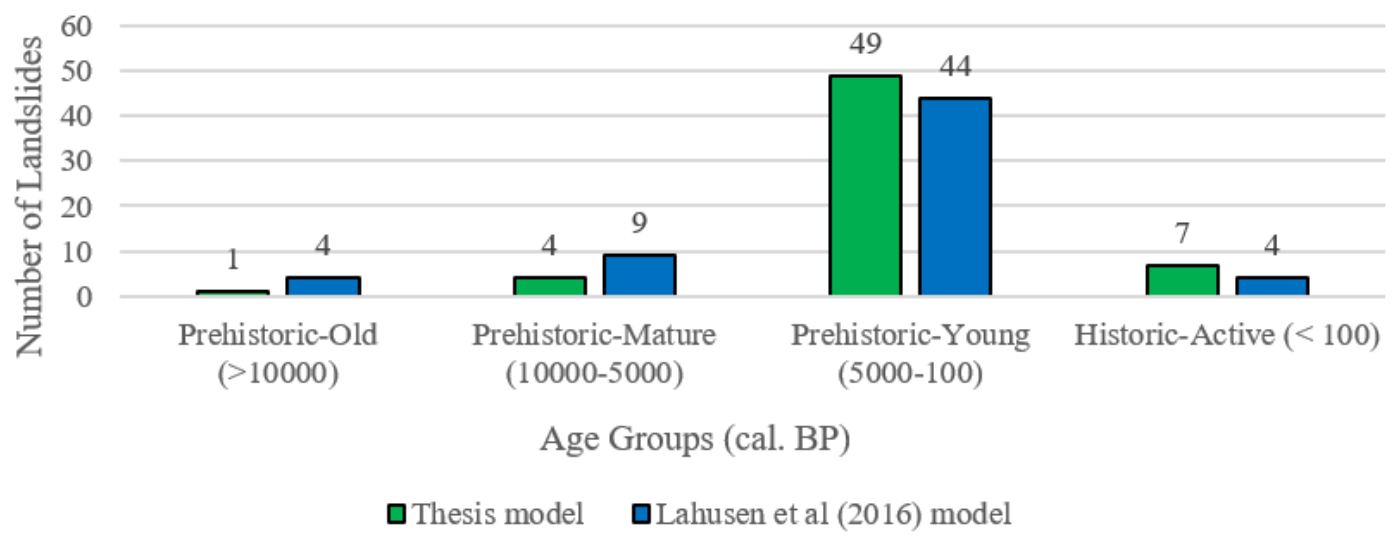

\section{$30 \mathrm{~m}$ window size}

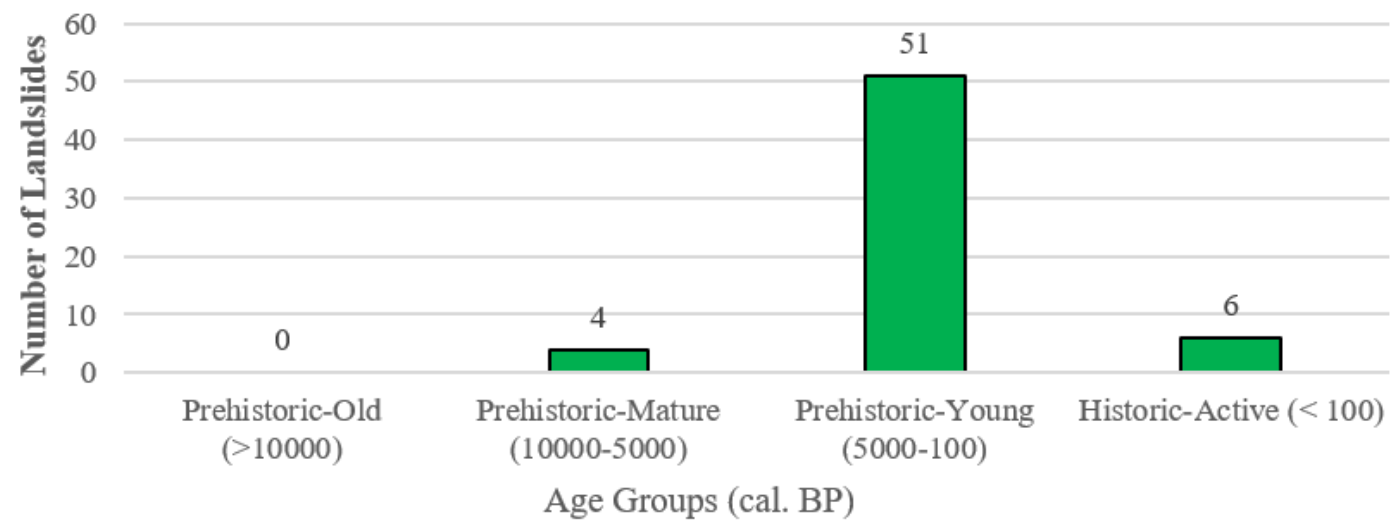

Figure 27. Absolute ages for each window size sub-divided into four age-classification groups in cal. BP. 


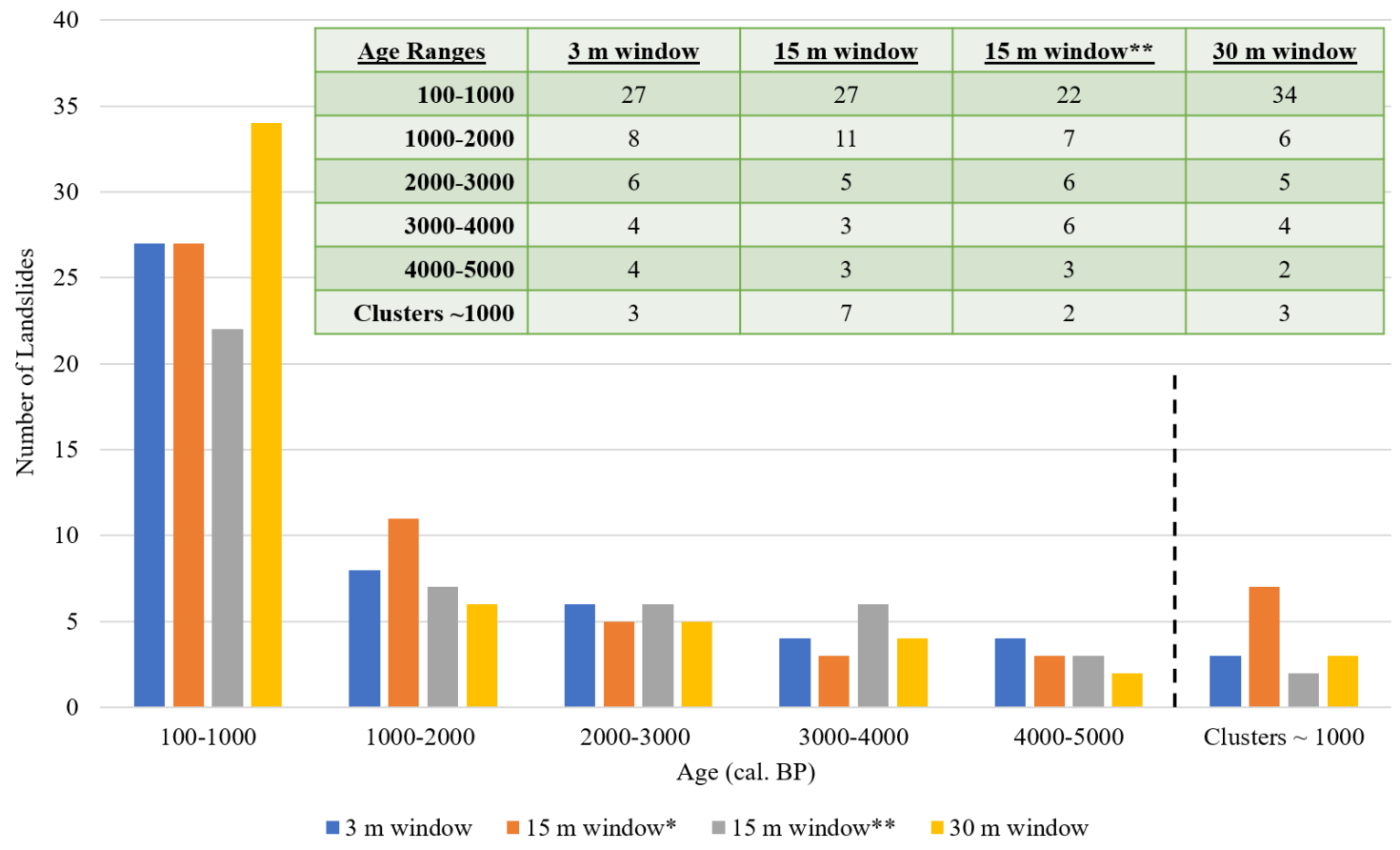

Figure 28. Number of landslides vs. subdivided age groups from the Prehistoric-Young (100-5000 cal. BP) age group. Ages that clustered around $1000 \mathrm{cal}$. BP are at the end of the graph (to the right of the black dashed line). (**LaHusen et al. (2016) model). 


\section{Analysis and Discussion}

\subsection{Spatial Patterns of Landslides}

Based on the river's longitudinal profile, the GRV within the study area has two main sections that are defined here as the lower reach and the knickzone. The lower reach, from 0 to 16.5 (valley) $\mathrm{km}$, has mostly adjusted to base level following deglaciation and has a gentler river gradient of $0.34 \%$. The knickzone, starting at approximately 16.5 (valley) $\mathrm{km}$ and extending through the eastern end of the study area, has a steeper gradient of $0.64 \%$. The majority of landslides in the GRV are found in the lower reach and at the downstream end of the knickzone from 0 to 22 (valley) $\mathrm{km}$. This is likely due to a combination of high relief and larger accommodation space made possible by a wider valley. Upstream from here there are fewer landslides due to a lower relief and decreased accommodation space. In the NFSR the majority of landslides were spatially located where the relief was high ( 150 to $200 \mathrm{~m}$ ) and the valley narrow ( 25 to $100 \mathrm{~m}$ ) (Keaton et al., 2014; Booth et al., 2017). A similar pattern is observed in one area of the GRV at the location of the knickzone where one of the landslide clusters is mapped (Figure 19). Here the valley width decreases sharply as the relief remains high. However, the GRV also has large numbers of landslides where the relief is high, but the valley is wide. Despite these differences in the effects of valley width, the threshold relief to trigger landslides was similar between these two study areas, with $>50-60 \mathrm{~m}$ of relief corresponding to minor landsliding, and relief >100 m corresponding to more widespread landsliding. Although landslides can play a part in shaping a river valley, the larger accommodation space in the lower reach of the GRV is likely caused by the incision of the river and its lateral migration 
over time.

Lateral migration trends of a river can often be controlled by slope failures that can block the river or change its course by pushing it towards the other bank (Dahlquist et al., 2018). Conversely, lateral migration driven by fluvial processes may trigger landslides by undermining adjacent hill slopes. Using aerial photos from 1936 and comparing them with aerial photos from 2017 shows the lower reach of the Green River has migrated from its north bank to its south bank in less than 100 years (Figure 29). Aerial photos from 1936 and 1998 were compared using a local road named SE Green Valley Rd where the lateral migration is the highest (Figure 30). As seen in the photos the road is in the same position indicating slope failure on the north side of the river was not the cause of the river moving laterally there, but instead lateral movement was likely due to meandering and meander cutoffs. Comparing these aerial photos also shows that this lateral migration did not trigger any large landslides to the south of the river.

Dated samples OW2 and TB3 are located within the lateral migration area and are interpreted to reflect the dates of smaller reactivations from the toes of older deposits (Figure 31). Sample OW2 has an age range of 492-219 cal. BP, which is partly verified by the fact that it is not captured by aerial photographs. Sample TB3 has an age of 0 cal. BP since it contained only modern carbon, and lidar and aerial photos allowed me to justify this age estimate. King County has lidar for this section of the Green River collected in 2003 that shows the landslide that sample TB3 came from already existed. After reviewing aerial photos, I was able to determine this landslide is also likely younger than 1936 (the oldest aerial photo available for this area). The scarp of this landslide shows up as a very sharp feature in lidar, but the scarp is not seen in the 1936 photo (Figure 32). The 1936 
photo is a good photo to use for a maximum age constraint because there are less trees and more open land within the landslide area. There is no discernable scarp in the 1936 photo where it is seen in lidar. The next most recent aerial photo from 1998 (and all aerial photos more recent then that) show thick vegetation cover, which can easily mask landslide features. Another feature noted in the 1936 photo is a road that can easily be seen wrapping around where the toe of the landslide would be in the photo. In lidar this road is also clearly seen but is not easily identified where the toe is. The area looks flat but the road is not a sharp feature. The landslide could have taken out this section of the road and the road since then could have been fixed and regraded over. From this we can still say this landslide is likely younger than 1936. However, the scarp could be too subtle to be seen in the old 1936 photograph which means I cannot completely rule out that this landslide could also be older than 1936. In that scenario, sample TB3 could have been buried from some minor gully related event any time since 1950 ( 0 cal. BP $)$, causing it to under estimate the age of the landslide. There is no clear evidence that this landslide caused the Green River to move laterally to the north in the last 100 years, and instead it is likely that the river laterally migrates naturally over time. There is an abandoned meander bend at the toe of this landslide, which suggests that it may have been triggered by river migration in the past and prior to the 1936 aerial photograph. The river is unable to migrate laterally as rapidly in other areas of the GRV due to more constrictions placed on the river from roads and homes and further upstream due to a narrower valley bottom width where the banks are bedrock rather than glacial sediments. Valley bottom width is also highest here where the river is actively migrating (from 8 to 10 valley $\mathrm{km}$ ). 


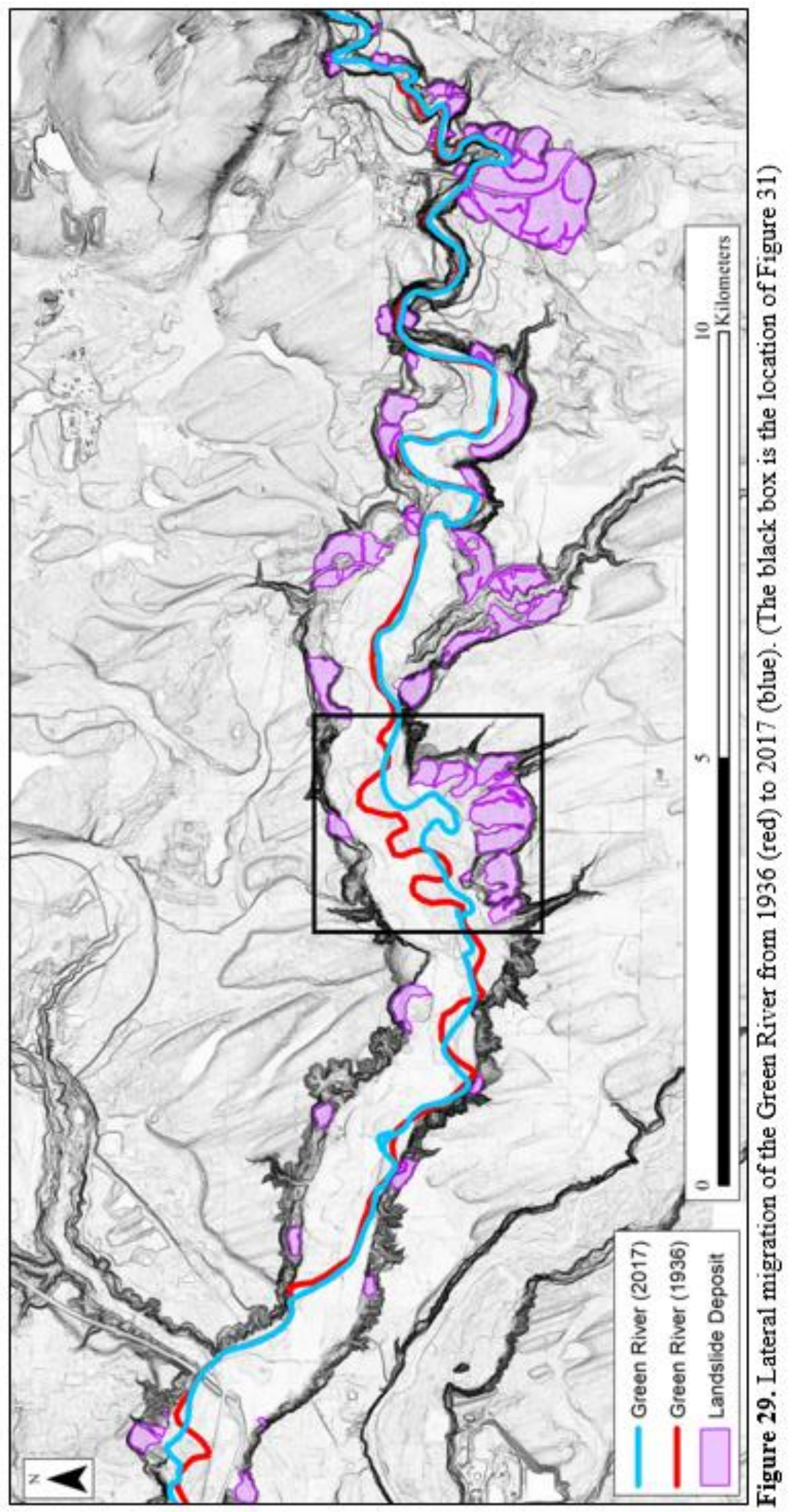




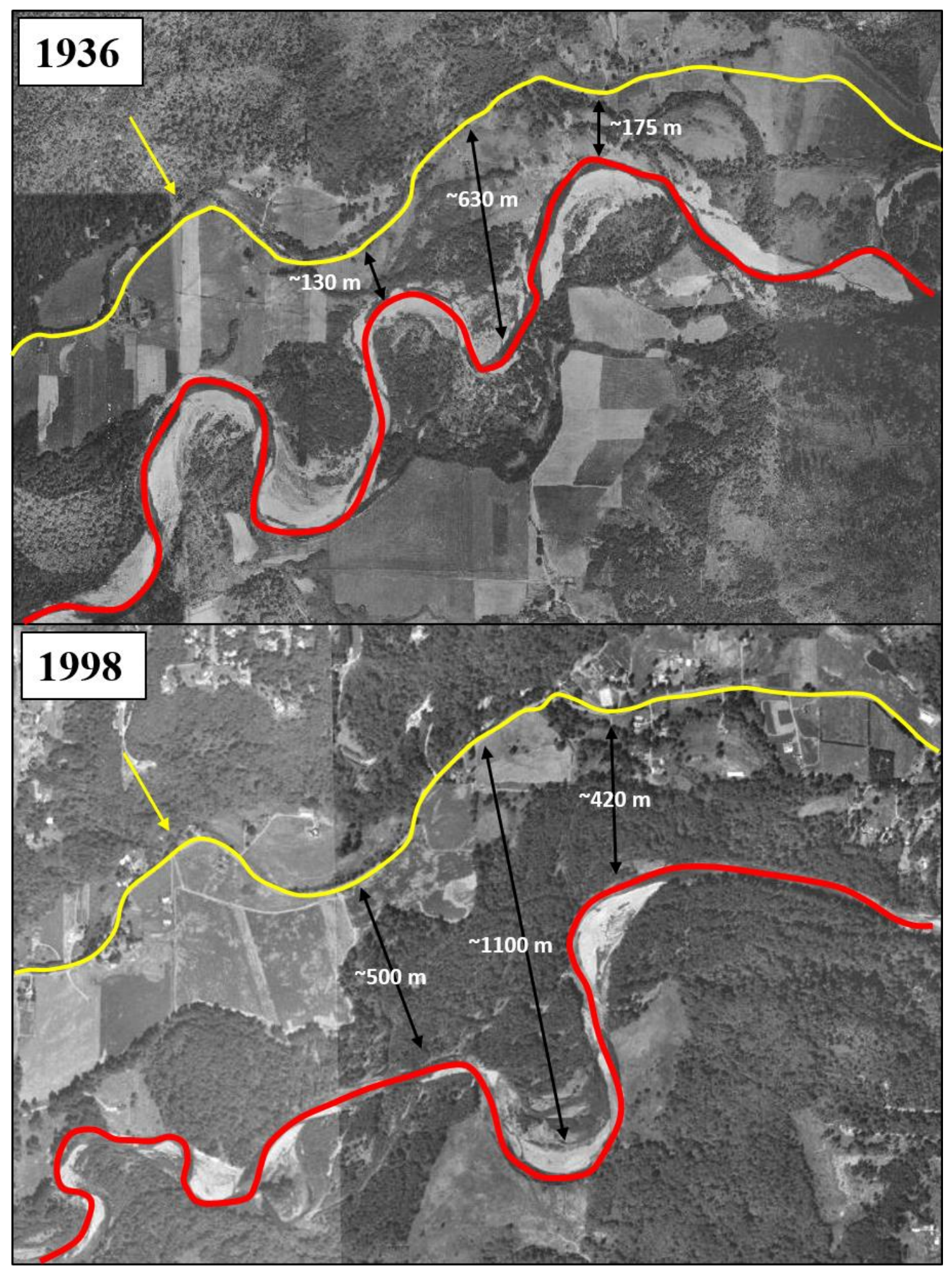

Figure 30. Aerial photo comparison of road location (yellow line) and Green River location (red line) from 1936 to 1998. The location of the road has not changed, while the river has moved laterally to the south by meander growth and cutoff. This indicates that slope failure was unlikely the cause of the river moving laterally during this time frame. 


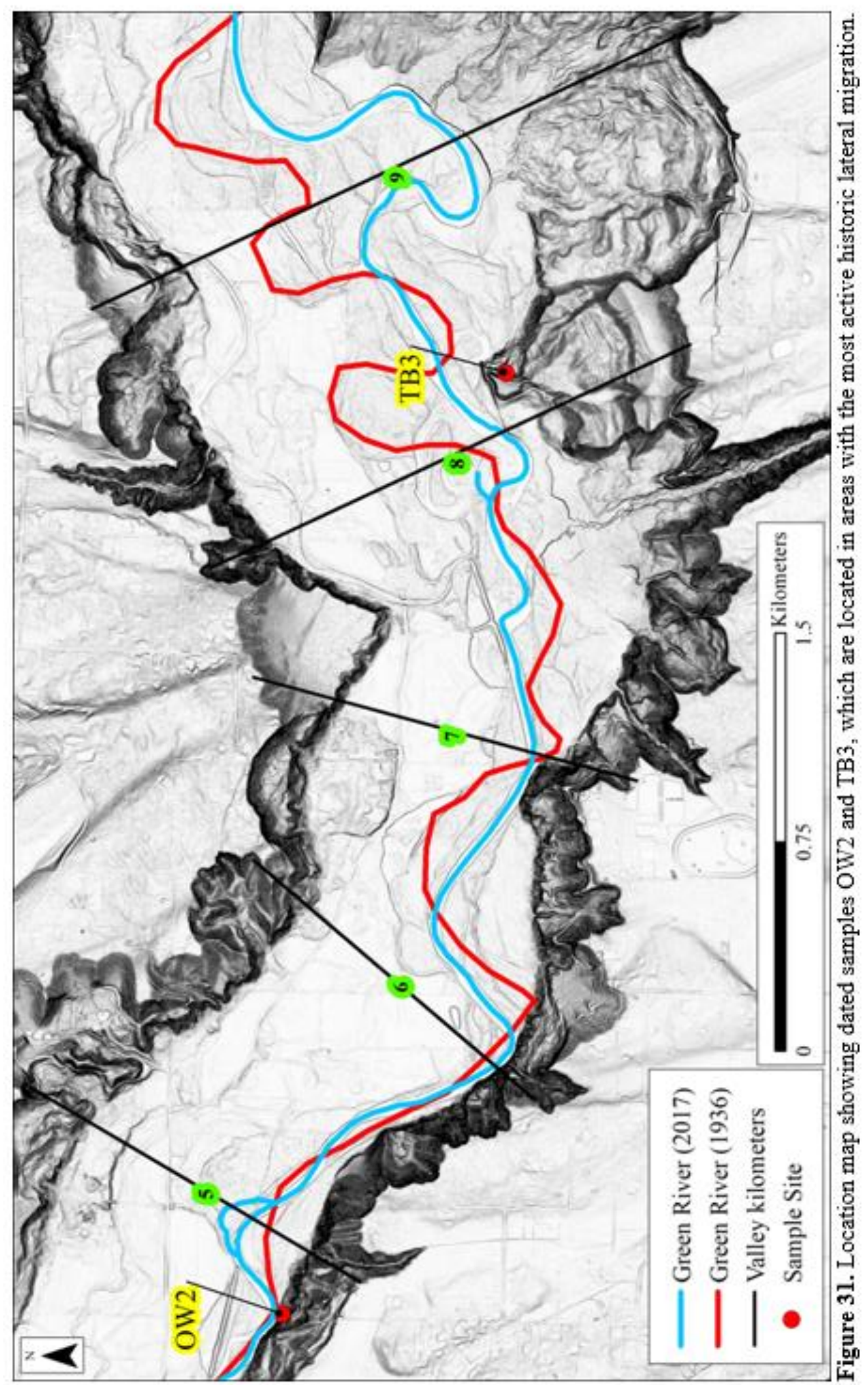




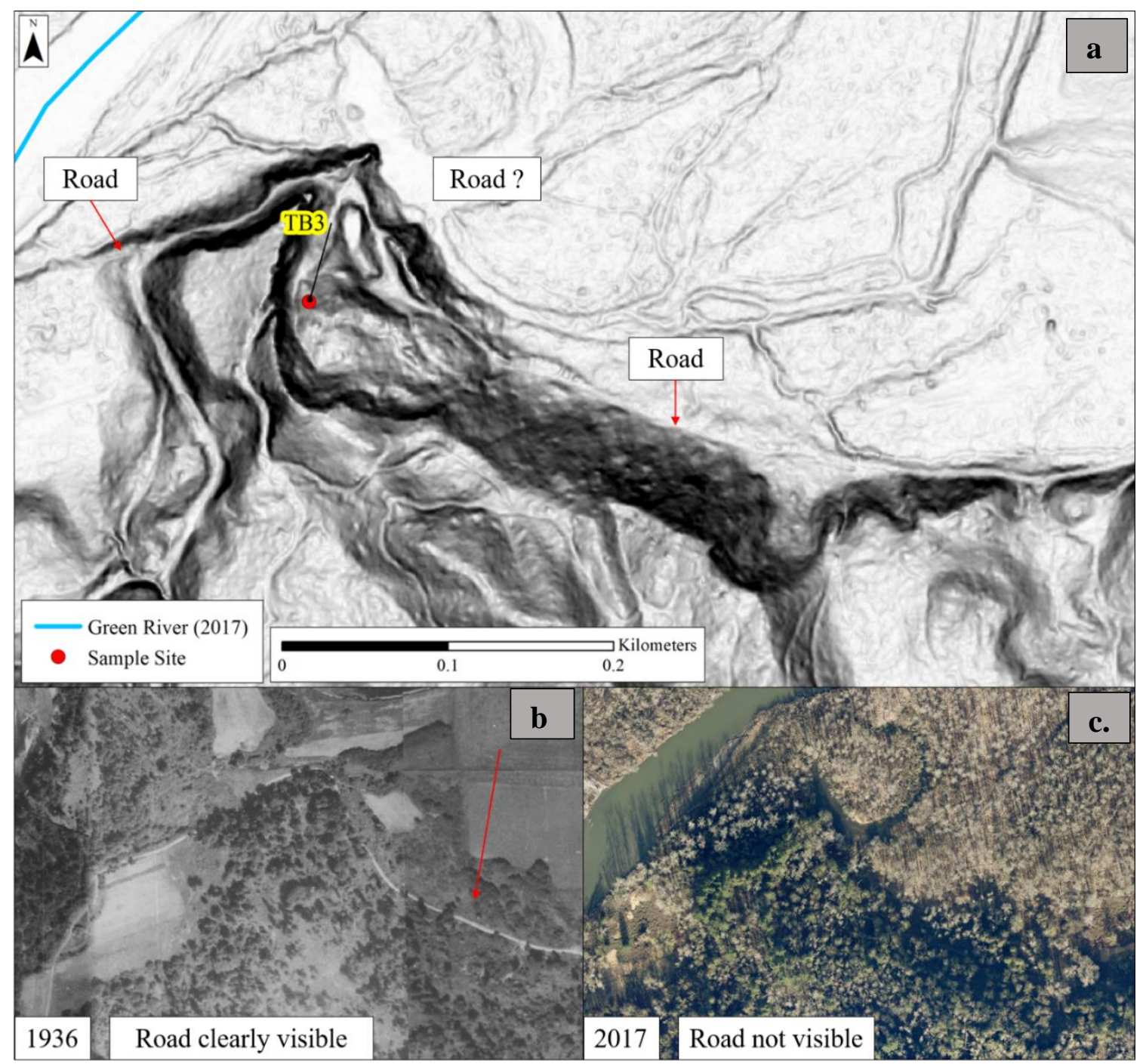

Figure 32. Landslide where sample TB 3 was dated as 0 cal. BP (modern). Lidar from 2003 shows this landslide existed prior to 2003 (Lidar in figure is from 2016). (a) In lidar the road is clearly visible on either edge of the landslide toe. (b) The 1936 aerial photo shows this road clearly, however, in (c) 2017 the road is obscured by vegetation.

Although I found no evidence of historic river lateral migration relating to historic landslides, the pattern of landsliding does show that the lower reach of the GRV, where valley bottom width is large, has a high number of landslides. This suggests that lateral migration of the river exerts a control on landslide locations over longer time periods. From 0 to 15 (valley) $\mathrm{km}$ the valley bottom width ranges from approximately 400 to $1100 \mathrm{~m}$ and 
has 36 mapped landslides. Some of these 36 mapped landslides are a part of two large landslide complexes. The widest part of the valley, in the area of active lateral migration ( 8 to 10 valley $\mathrm{km}$ ), has a large landslide complex totaling seven landslides, and just further upstream (11 to 13 valley $\mathrm{km}$ ) is a second landslide complex with a total of 5 landslides. Although valley bottom width from 0 to 15 (valley) $\mathrm{km}$ is on average approximately 850 $\mathrm{m}$ wide, there are more landslides at the upper end of this section than further downstream. On lidar, downstream of these two landslide complexes, only a few small bank failures are visible, and they are predicted by the age-roughness models to be relatively old. As the Green River adjusted to base level after deglaciation this area of the GRV could have rapidly incised into the overlying glacial sediments and caused wide spread landsliding in the early Holocene. If landsliding occurred early on in this part of the GRV this could have given the Green River time to laterally migrate, further increasing valley bottom width by eroding prehistoric landslide deposits and masking any trace of them. The lower number of Active-Historic landslides at the downstream end of the study area could also be due to the land being more modified with roads and structures thus restricting the natural migration of the river.

Upriver from this section, from 15 to 16 (valley) $\mathrm{km}$, is the location of the downstream end of the knickzone. Here the valley bottom width decreases rapidly from 400 to $80 \mathrm{~m}$. The lower end of the knickzone, where landslides are mapped, varies from 49 to $100 \mathrm{~m}$ in width and also has a large landslide complex between 18 to 20 (valley) $\mathrm{km}$. The knickzone is assumed in this area because of its change in gradient to approximately double that of the downstream reach. A higher gradient, all else being equal, may increase the incision rate of the river in this area, or more generally, the knickzone indicates that 
this reach of the river may be in a transient state where it is still adjusting to isostatic uplift and relative base level fall at its outlet. Due to the constriction of the valley here, the river is likely incising at a higher rate compared to downstream, rather than laterally migrating, causing more frequent instability along its slopes. The large landslide complex located in the knickzone is on the south side of the GRV and contains 10 landslides. This is the largest landslide complex within the study area, and also has the highest local relief of 184 meters. Furthermore, many of the landslides in this complex are directly dated or predicted to be young. This example shows that local relief has a stronger control on the rate of landsliding than valley bottom width.

Relief varies within the study area and is different on the north and south sides of the valley. Where there are mapped landslides from 0 to 15 (valley) $\mathrm{km}$, local relief on the north side ranges from 79 to $117 \mathrm{~m}$ and on the south side from 63 to $123 \mathrm{~m}$. This gives us an estimated threshold relief of approximately $60 \mathrm{~m}$ for this section of the study area where valley bottom width is the greatest. Starting downstream, just before the first large landslide complex at valley kilometer 8, there are few Active-Historic (modern) landslides even with a high relief and large accommodation space. Here we could have a lower modern incision rate due to a combination of a shallower river gradient and the Green River being in a more urban environment that would restrict its north/south lateral movement as seen further upstream where lateral migration is high. Although the valley constricts further upstream, the relief is still high, so landslides still occur despite a decrease in accommodation space. This is even more evident from 18 to 21 (valley) $\mathrm{km}$ where a large landslide complex is located in the knickzone. Despite a lack of accommodation space there are many landslides there. Most of those landslides toe out at the river suggesting that the Green River could 
have been temporarily blocked by failures many times. However, because of the steeper gradient it is likely the river was able to cut through those deposits rather easily and likely dispersed any debris from the landslide further downstream, erasing any signature within the channel itself (Costa and Schuster, 1988). A recent example of this is the devastating SR 530 (Oso) landslide that occurred in 2014 which blocked the NFSR. However, within days the river was able to breach the deposit (Wartman et al., 2016).

Despite high local relief on either side of the valley, the majority of landslides within the study area are found on the south side of the GRV. This could be expected as the underlying geology is different on the south side than the north side. The south side of the GRV has 41 mapped landslides compared to only 20 on the north side. The south side, from 0 to 15 (valley) $\mathrm{km}$, is underlain by the Osceola mudflow deposit from a Mt. Rainier eruption approximately 5,600 cal. BP. The Osceola mudflow deposit is not mapped on the north side of the GRV suggesting it either didn't reach the river or it has since been washed away. Its varied thickness, from 10s of meters to centimeters, could be responsible for more widespread landsliding seen on the south side due to an overloading of the slope from above, or from rapidly supplying large volumes of water. The mudflow was a volcanic debris flow (lahar) and was able to entrain and deposit material as large as boulders and trees along with the smallest clay sized particles (Vallance and Scott, 1997). The debris from this lahar could have been responsible for adding overburden to an already weakened slope. Landslides can creep for many years on a pre-defined failure plane without failing catastrophically. Rapidly adding a deposit up to 10 's of meters thick under undrained conditions could have transiently increased pore pressures and the driving forces, which could cause a landslide to go from a slow moving failure to a more catastrophic one 
(Hutchinson and Bhandari, 1971). There are three landslides in the study area that have ages of $5600+/-200$ cal. BP. All three of these landslides are on the south side of the valley, in the same landslide complex, and are in an area where Osceola Mudflow deposits have been mapped (Figure 37).

The Osceola Mudflow could have played a part in the widespread landsliding seen on the south side in this area of the GRV. However, further upstream at the location of the largest landslide complex (and where the valley is constricted) there are no mapped mudflow deposits. The underlying geology here has exposed bedrock on both sides of the GRV and as a whole is stronger than the glacial deposits that overlie it, which could be why the valley is so constricted here. The large landslide complex between valley kilometers 18 and 20 is mapped as glacial deposits overlying bedrock. What's noticeable in the lidar and was confirmed in the field is that the landslides here are failing on contacts above modern river level, either at the interface between glacial sediments and bedrock, or within the glacial sediments, but not within the bedrock. Downstream, the toes of these landslides are mostly at modern river level with failure planes developed in glacial sediments. Evidence of ground water seeps at the sediment-bedrock interface indicates that high pore pressures due to a permeability contrast are likely generated there to promote failure. This further supports the interpretation of a higher incision rate in this upstream section of the GRV and base level adjustment in the lower section. 


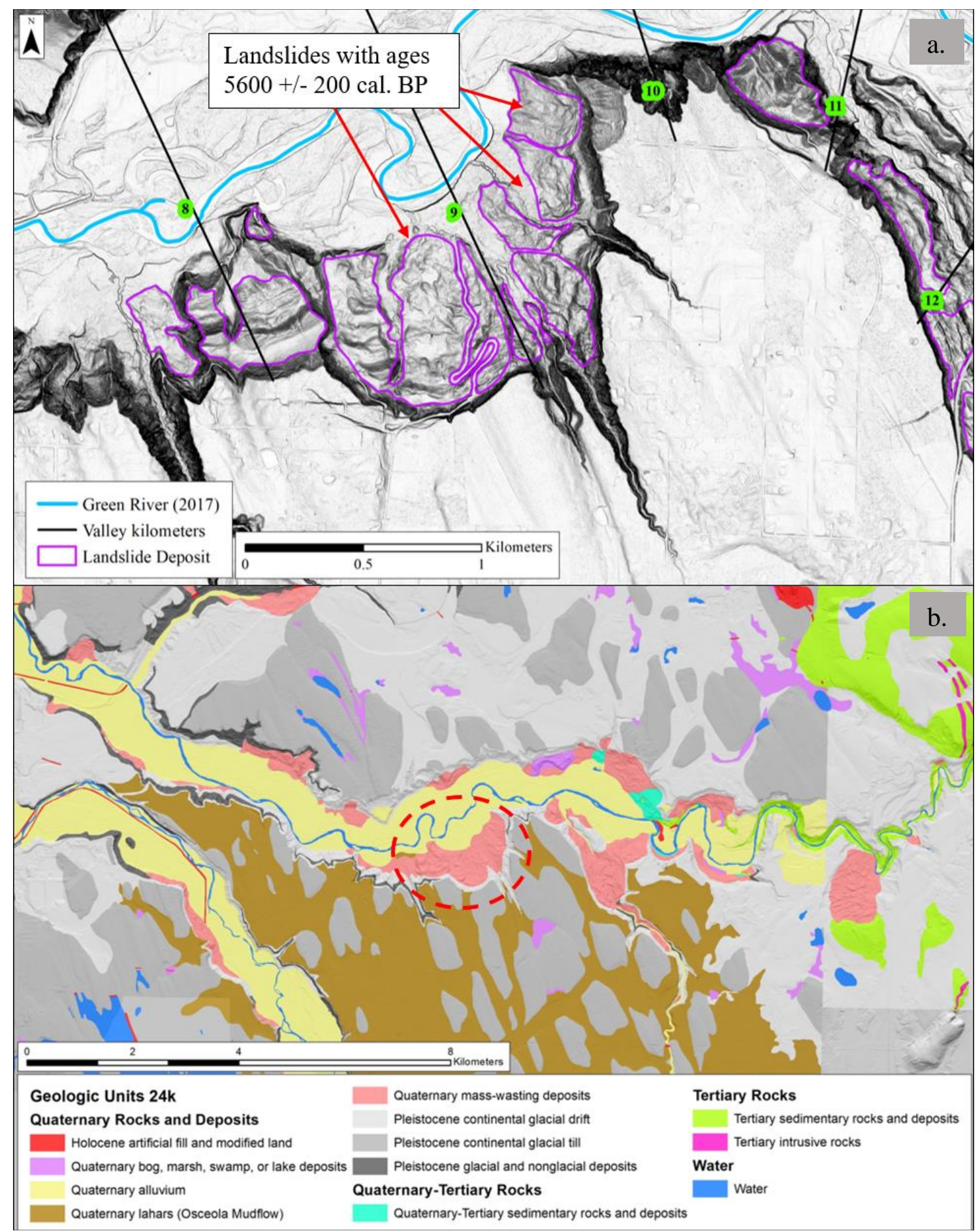

Figure 33. (a) Lidar map showing the three landslides with ages consistent with the timing of the Osceola Mudflow 5,600 cal. BP. (b) Geologic map showing the whole study site and the location of the three landslides (red dashed circle). 


\subsection{Roughness-based Relative Ages}

The standard deviation of slope in a $3 \mathrm{~m}$ window is the best window size for relative age dating in the GRV. This window size correctly identified 25 out of 30 cross cutting relationships (83.3\%). Importantly, even where roughness values did not predict the correct relative age relationship, the roughness values were usually quite close to each other. Landslides in the valley vary by size from less than $10^{3} \mathrm{~m}^{2}$ to $10^{6} \mathrm{~m}^{2}$ which may factor into why the accuracy isn't higher. There were four cross cutting relationships that all three window sizes' roughness values did not match (Figure 34). Three of these landslide pairs involved a younger, smaller landslide with its lateral margin cut into an older, larger landslide, while the fourth pair involved a reactivation of the toe of an older deposit. For Landslide ID 12 and 13 (Fig. 34a) there is a difference in surface texture that may reflect different landslide styles. The younger, smaller landslide appears to show characteristics indicative of a more fluidized landslide, whereas the older landslide has large hummocks and/or rotated blocks indicative of a rotational slump. Their surface morphologies are visually different, and they also have quantitative roughness values that do not match their cross cutting relationship. For Landslide ID 25 and 26 (Fig. 34b) the inconsistent roughness values could be because of how heavily modified these deposits were. Both had extensive buffering to remove roads and land where structures were located, so the unmodified surfaces used to calculate roughness were a relatively small sample of the total landslide deposit area, which could introduce bias. Landslide ID 46 and 47 (Fig. 34c) shows a relationship where ID 47 cuts into ID 46 which would make it younger. However, the surface roughness on the younger landslide is much smoother than the one it cross cuts into. Both of these landslides also have surface roughness signatures that look more 
fluidized as noted in ID 12. Another possibility is that the older landslide could have reactivated near its scarp without moving enough to develop a clear lateral margin where it borders the younger deposit. In that case, reactivation would have likely rejuvenated the surface roughness without clearly defining a new cross-cutting relationship.

Some of the younger landslides in the valley are reactivations within an older deposit such as landslide ID 7 and 8 (Fig. 34d), the fourth pair that all three window sizes did not correctly identify. This type of failure could have different surface roughness signatures as the land is already distressed from the original failure. An originally consolidated material, which became more unconsolidated by the initial landslide, may not fail in blocks, but reactivate with more fluidized behavior such as a flow. Based on the rules of cross cutting relationships Landslide ID 7 should be older than Landslide ID 8, but all three window sizes calculated a higher average roughness for ID 7. The reason that all three window sizes are calculating the older landslide to be younger is because it is visibly blockier in lidar. The part of the slope that reactivated close to the toe doesn't have that blockier appearance. Its surface roughness looks 'smoother', so its standard deviation of slope is going to be lower.

The $3 \mathrm{~m}$ window size roughness analysis also correctly characterized two cross cutting relationships that the $15 \mathrm{~m}$ and $30 \mathrm{~m}$ window sizes did not (Figure 21). One of those correct characterizations is from Landslide ID 42 and 43, located within the large landslide complex upstream in the knickzone. Landslide ID 42 is the largest landslide in the GRV, and the younger, inset landslide 43 is where sample BD1 was acquired with an age range of 372 to 0 cal. BP. Landslide ID 42 is identified from cross cutting relationships to be the older of the two landslides, however, geotechnical reports going back to at least 1995 say 
this landslide is actively moving (Allen \& Lowell, 1995). Landslide activity that postdates the initial failure may have generated new surface roughness, making the landslide appear younger in terms of its surface roughness than its actual initiation age. The other correct characterization made by the 3 meter window size roughness corresponds to Landslide ID 55 and 56 located even further upstream. These two landslides have a very low surface roughness, almost masking any discernable features and cross cutting relationship. The 3 meter window size was able to see finer detail over the $15 \mathrm{~m}$ and $30 \mathrm{~m}$ window sizes so was able to correctly identify this cross cutting relationship. The $15 \mathrm{~m}$ and $30 \mathrm{~m}$ window sizes being used for surface roughness analysis may be too big to capture the smaller features associated with the smallest landslides, and are more influenced by the boundaries of the landslide deposit. Another factor that may affect surface roughness analysis is the different types of landslides. Deep seated landslides dominate the GRV with their blocky and hummocky appearance, while some landslides failed as an earth or debris flow. These two different styles of landslides (slide or flow) may have different surface roughness signatures, which may be why not all cross-cutting relationships were identified by the standard deviation of slope. When defining an empirical age-roughness model this type of difference in landslide style also adds uncertainty to estimating absolute ages to prehistoric landslides, as discussed in section 4.4 below. 


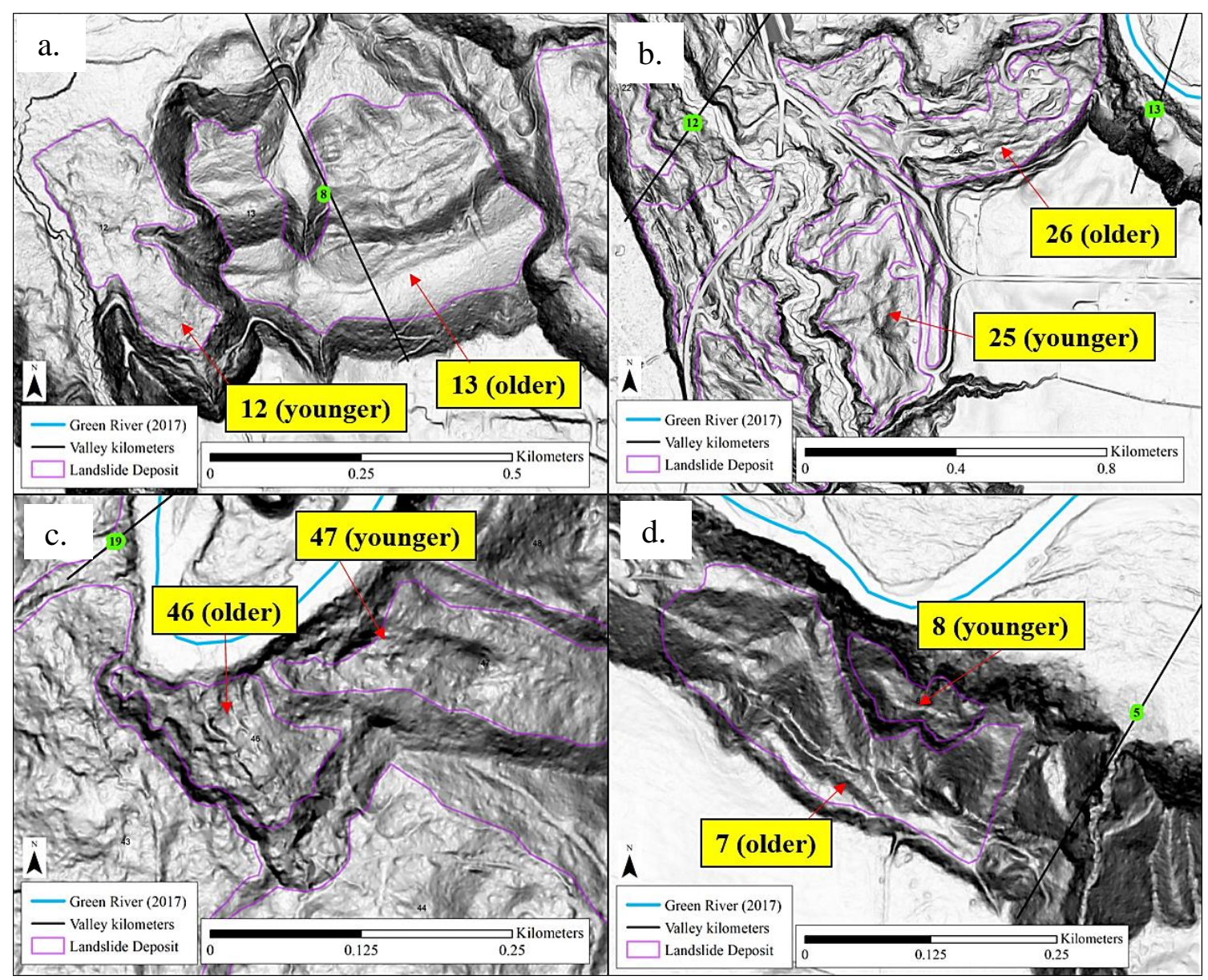

Figure 34. All three window sizes did not correctly match their roughness values with these cross cutting relationships.

4.3 Radiocarbon Dating

Radiocarbon dates for the wood collected in the GRV range from Modern to over 40,000 cal. BP. Since all landslides in the valley must be younger than approximately 16,400 cal. BP when the Puget Lobe retreated, this wide range of ages implies that care must be taken to interpret landslide ages from radiocarbon dating. The four youngest radiocarbon dates were calibrated and had an age range of 492 to 0 cal. BP, one had an age range of 41494 - 42591 cal. BP and the other two samples were considered 'carbon dead.' The four youngest samples were collected on the valley's south side and were all found in reactivations of older deposits. The three older samples $(>40,000$ cal. BP) were collected 
from deposits on the valley's northern side. Two of the carbon dead samples were located in the same deposit, and the other one with an age of $41494-42591$ cal. BP was located in a reactivation of an older deposit. All three of these older samples tell us that the woody debris located in the deposit was already buried there before the post-glacial landslide occurred and therefore is not indicative of that landslide's age. The deposits these samples came from are mapped as either the Hammer Bluff formation (an upper Miocene member) or the Orting Drift (a lower Pleistocene member). The Hammer Bluff formation is known to have wood fragments in its deposit (Mullineaux, 1970), although the carbon dead samples came from well preserved branches and a large log (Figure 10) and therefore are likely not Miocene in age. The Hammer Bluff formation is a late Tertiary age sedimentary rock that is only known to be a few 10's of meters thick (Mullineaux, 1970). These branches and the log, were they indicative of the Hammer Bluff formation, would have to be over 1.8 million years old and remain intact during deposition and reworking of the deposit by repeated glaciations. Instead, what is probable is that the $\log$ and branches became entrained in a pre-LGM landslide that mobilized Orting Drift that would have then had its surface signature scoured by the advancing and retreating of the ice sheet.

To summarize, although radiocarbon dates of organic material in landslide deposits are often interpreted as a close maximum age (Panek, 2015), remobilization of older deposits can cause severe overestimations of landslide age when those deposits contain woody debris. Radiocarbon dates can also underestimate landslide age if the date corresponds to an unrecognized smaller reactivation of a larger landslide complex, but this can be avoided with careful lidar and field-based mapping. 


\subsection{Preliminary Age Roughness Model and Landslide Timing}

Existing conceptual models predict that the youngest landslides in a valley are expected to be in a knickzone, with more degraded and older landslides occurring downstream (Palmquist and Bible, 1980). This implies that landslides are triggered by the pulse of base level fall that occurs as the knickpoint migrates upstream. To test this hypothesis, landslides in the GRV were assigned an age group (Prehistoric-Old, Prehistoric-Mature, Prehistoric-Young, Historic-Active) based on the calculated ages generated from the age-roughness model of the $3 \mathrm{~m}$ window size. There is a high concentration of landslides that fall within the Prehistoric-Young (5000 to 100 cal. BP) age group in all three window sizes (Figure 27). Although only the $3 \mathrm{~m}$ window size map is shown, those landslides span the entire study area in all three window sizes (Figure 35). As previously noted, to better understand this age group, I further subdivided those landslides into smaller intervals using the $3 \mathrm{~m}$ window size age-roughness model (Figure 28 and 36). Only the $3 \mathrm{~m}$ window size was analyzed because it had the highest accuracy for cross cutting relationships and explained the highest percentage of the variance in the absolute age data (i.e. had the highest R-squared value). From the map (Fig. 36) there appears to be a decreasing trend in age as you move upstream, consistent with the base level triggering hypothesis. This decreasing trend in age (younger landslides) also has a higher area of landslides as you move upstream towards the knickzone (Figure 37). Focusing on the three landslide complexes in this area, the landslide complex furthest downstream has the oldest landslides while the landslide complex furthest upstream (at the knickzone) has younger landslides. To verify this I took the average landslide age for each complex for landslides 
that were from 5,000 to $100 \mathrm{cal}$. BP. The landslide complex furthest downstream has five landslides within this age range with an average age of 2,558 cal. BP. The second landslide complex also has five landslides within this age range, but it has a younger average age of 1,390 cal. BP. The landslide complex furthest upstream and within the knickzone has seven landslides that range from 5,000 to $100 \mathrm{cal}$. BP with an average landslide age of $502 \mathrm{cal}$. BP.

Quantitatively analyzing the age of prehistoric landslides is essential to interpreting the frequency of past landslides and gives us better predictions for the likelihood of future slope failures. Preliminary age roughness models were made for each window size to determine what age ranges they capture. From the results above all three window sizes predicted that the vast majority of landslides were in the Prehistoric-Young age group. This correlates broadly with the climate changing from a dry and warm environment to a wet and cool one around 6,000 cal. BP (Brubaker, 1991). When this age group is further subdivided, the number of landslides increase as they get younger (Figure 37). One reason for this could simply be preservation bias, that the older deposits have been scoured away by the river or been modified by people so there are less of these in the landslide inventory. By far there is a higher concentration of landslides from 100 to $1000 \mathrm{cal}$. BP. The $30 \mathrm{~m}$ window size had the highest number of 34 landslides followed by the $3 \mathrm{~m}$ and $15 \mathrm{~m}$ window size having 27 landslides each, and the LaHusen et al. (2016) model with 22 landslides (Figure 28). Three of the four younger samples, OW2, BD1, and FG1, have cal. BP age ranges that fall within this age group that would also fall within the margin of when the last Cascadia Subduction Zone Earthquake occurred just over 300 years ago. From 5000 cal. BP to 100 cal. BP, the frequency of preserved landslide deposits has steadily increased 
(Figure 28 and 37). From 1000 cal. BP to present, there were 26 landslides, which gives a recurrence interval of approximately one landslide every 38 years. This is a marked increase compared to approximately 6 landslides per 1000 years from 5000 to 1000 cal. BP (one landslide every 167 years). This increase in landslide frequency does not correspond to dramatic changes in base level or climate, and may instead be related to seismicity on crustal faults, such as the Seattle Fault and the Tacoma Fault. Those two faults are all known to have produced earthquakes within the last 1,100 years (Gomberg et al., 2010).

Overall, I infer that the three main landslide triggering mechanisms (base level fall, climate, and seismicity) have all played a role in controlling landslide frequency in the GRV. Specifically, rapid incision brought on after the retreat of the last ice sheet 16,420 cal. BP left the hillslopes deeply incised and highly susceptible to landsliding. That in combination with the climate changing to a cooler and wetter one likely increased the pore water pressure within these hillslopes making them even more unstable. Landslides with dates that correspond to past seismic events and the Osceola Mudflow were likely highly unstable before failure. 


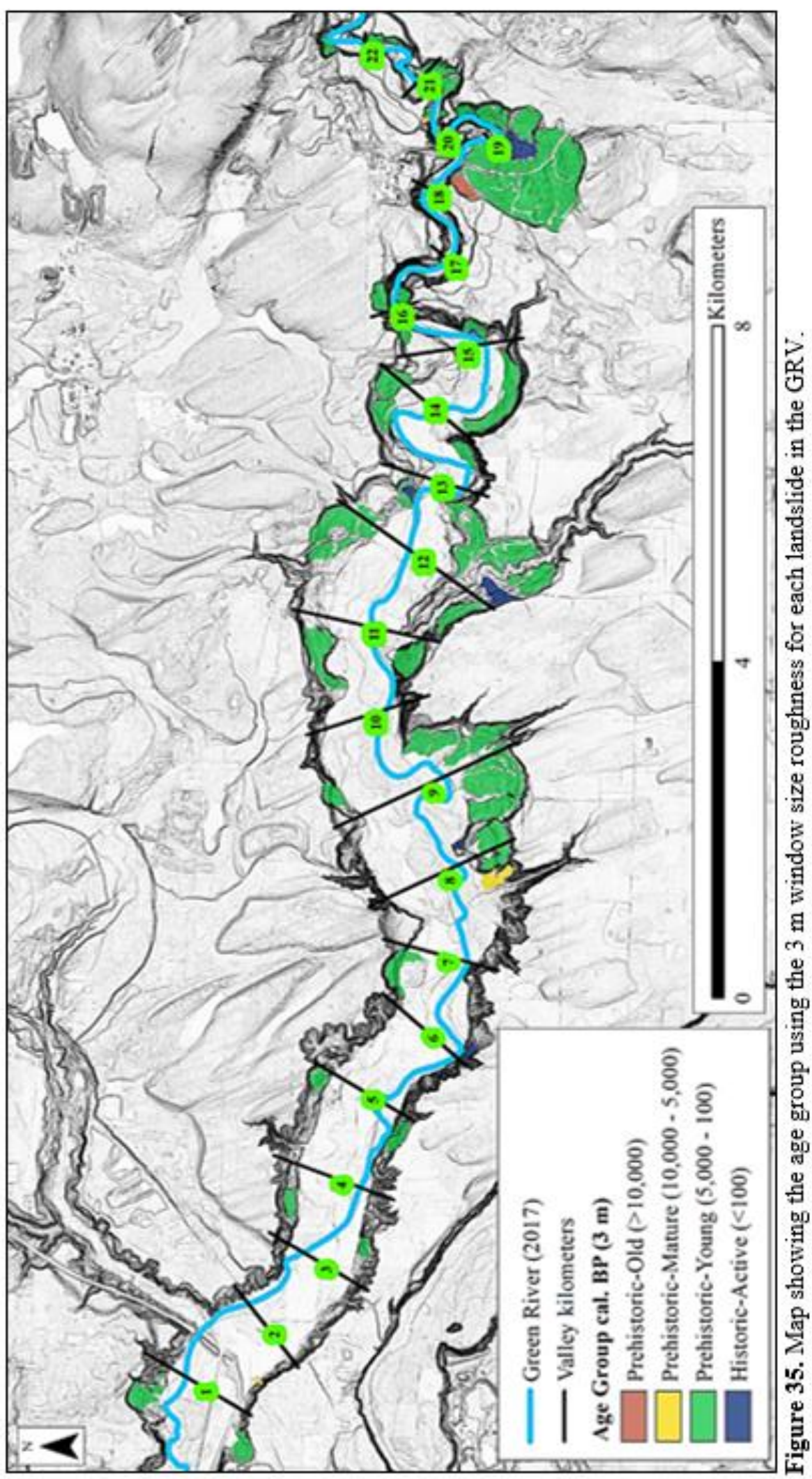




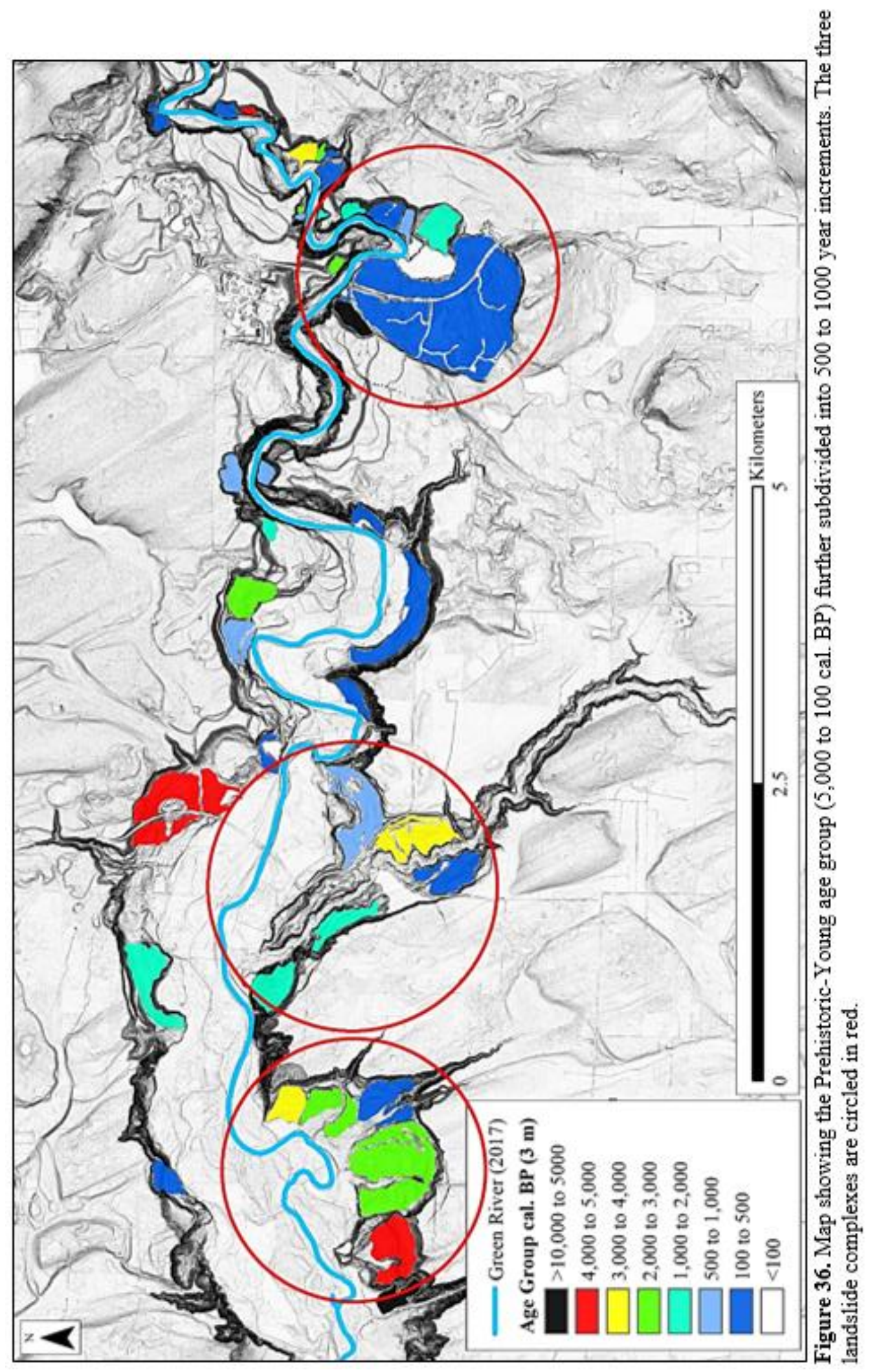




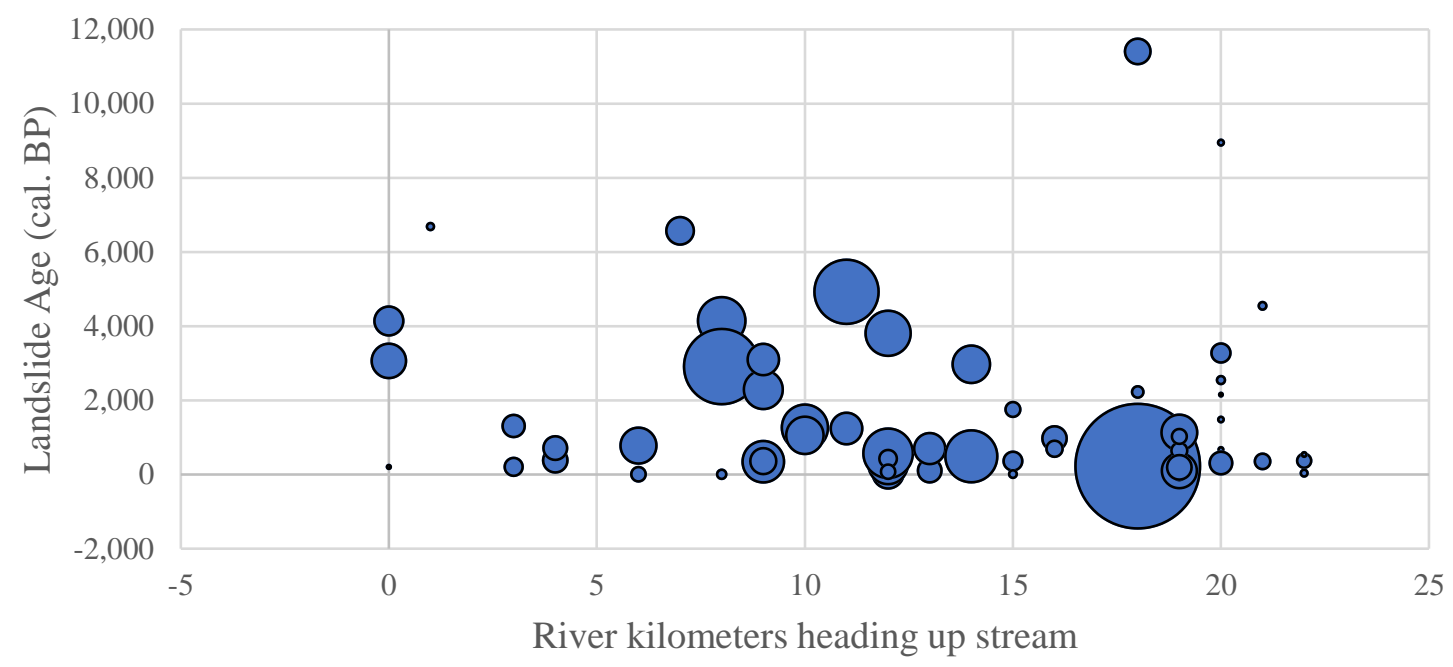

Figure 37. Bubble plot showing predicted age of landslides vs. river kilometer, with the size of the bubbles proportional to the area of the landslide.

Number of landslides (per 1000 years) in the Green River Valley

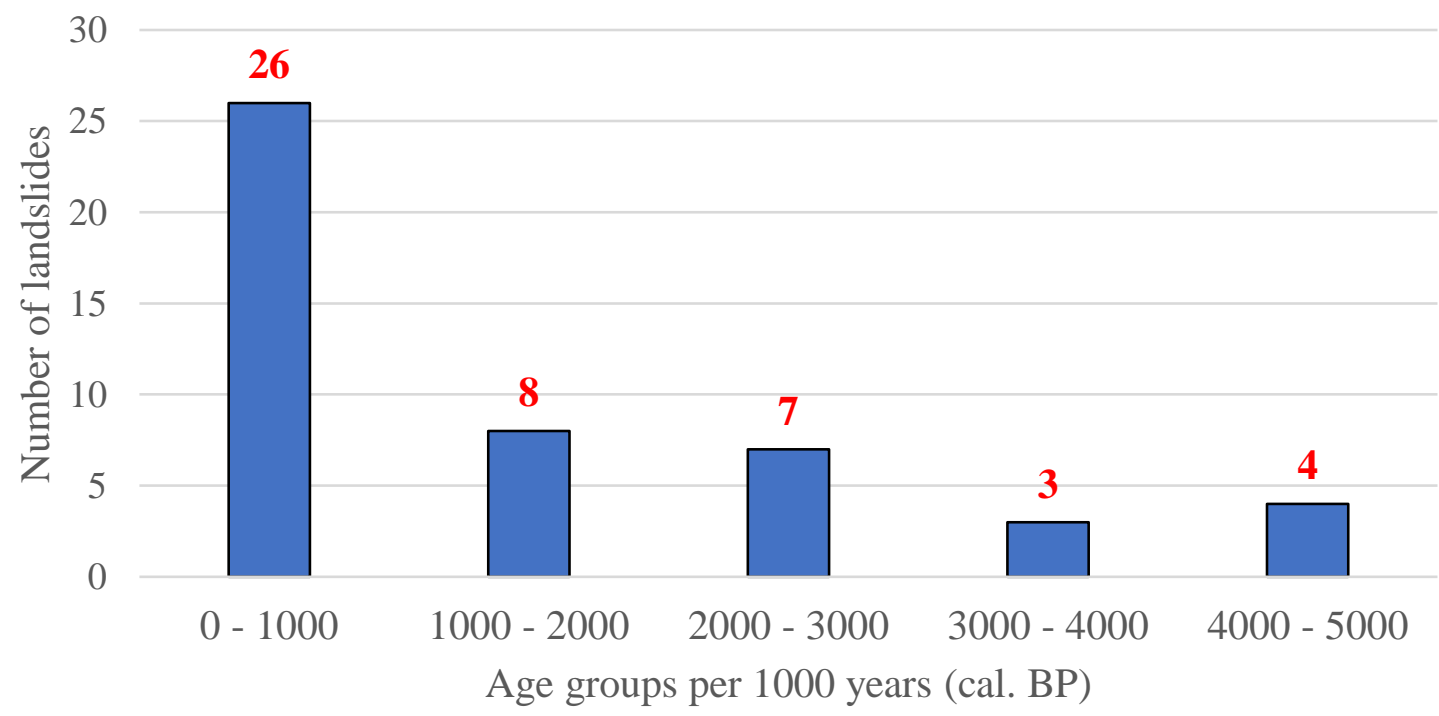

Figure 38. Graph showing the number of landslides is increasing since 5,000 cal. BP with 26 landslides in the last $1,000 \mathrm{cal}$. BP. 


\subsection{Future Work}

Future research might categorize these landslides even further by type (deep, shallow, debris), size (large or small), and modified/unmodified. A more detailed understanding of the subsurface stratigraphy could also tell us what type of deposits the slopes in the GRV are failing in. Future work should include a detailed landslide hazard map for the Green River Valley that would include landslide susceptibility based on where landslides occur in the valley, under what conditions they failed, and the type of landslides that were produced. 


\section{Conclusion}

This study focused on understanding the spatial and temporal pattern of prehistoric landsliding in the Green River Valley of King County, Washington. This included analyzing the number of landslides in relation to relief and valley bottom width, running surface roughness analysis using lidar on three different window sizes $(3,15,30 \mathrm{~m})$, and comparing those surface roughness results with cross cutting relationships to understand the degree of accuracy. The main goal was to increase understanding of where and when these 61 landslides happened in the GRV and under what conditions those slopes might have failed.

The landslide inventory for the GRV shows that the vast majority of landsliding is observed downriver where the valley is wide, however, there is a large landslide complex upstream where the valley starts to constrict. Within the study area there is a minimum relief of 50 meters where below that no landslides are observed and an average local relief of 60 meters where landslides are likely. Where the valley starts to constrict is coincident with a knickzone where the river gradient approximately doubles. This increase in slope may also likely cause a higher incision rate, allowing the Green River to incise into the bedrock and form the gorge in this part of the GRV. I infer that this is why landsliding happens above river level at the bedrock/glacial sediment contact. In this area of the GRV, where the large landslide complex is located within the knickzone, relief is also highest. Statistically, relief and not valley bottom width, is a stronger control on landsliding in the GRV. 
Results from the surface roughness analysis show that the $3 \mathrm{~m}$ window size had the highest accuracy (83.3\%) when compared to cross cutting relationships. However, this window size only correctly identified one more relative age relationship than the $15 \mathrm{~m}$ window size and two more than the $30 \mathrm{~m}$ window size. The $3 \mathrm{~m}$ window size was more successful in correctly identifying relative age in part to the variation of landslides within the GRV. The valley is mostly dominated by large, deep-seated, hummocky type deposits, but there are multiple smaller landslides and landslides whose surface roughness signatures look more fluidized. The $3 \mathrm{~m}$ window might have been more successful, especially with the more smoothed out deposits, in quantifying surface roughness because it was able to see more detail within the deposit.

The Green River Valley becomes more urbanized in the downstream direction. Landslide deposits have been modified for the purpose of building roads and houses. Although care was taken to buffer out these modified areas, it also limits the amount of surface roughness available for analysis. Despite the limitations of the age-roughness models they still provide us with information regarding when these landslides happened in relation to each other. The standard deviation of slope is a useful tool when comparing against cross cutting relationships and still betters our understanding of when and where landsliding occurred in the Green River Valley.

Key radiocarbon results showed that the four youngest dated samples (492 to 0 cal. BP) came from landslides on the south side of the GRV, and the three oldest dated samples (> 40,000 cal. BP) came from landslides located on the north side of the GRV. The three oldest samples were inferred to not be indicative of landslide age so were not used in this 
analysis. The four youngest samples were essential in developing age-roughness models that helped determine absolute ages for all 61 landslides in the valley.

To assign ages to all landslides in the valley, including those not directly dated, I developed age-roughness models for each window size to determine where and when landsliding was occurring in the valley. All three window sizes predicted that the majority of landslides were in the Prehistoric-Young (5,000 to 100 cal. BP) age group, which is consistent with the climate changing from warmer and drier to cooler and wetter. Some of these landslide ages were also consistent with past seismic events such as the last earthquake on the Seattle Fault (1000 cal. BP) and Cascadia Subduction Zone (250 cal. $\mathrm{BP})$. The $15 \mathrm{~m}$ window size showed seven landslides that failed around the time of the last earthquake on the Seattle Fault. There is a steady increase in landslide frequency of approximately one landslide every 330 to 125 years in the GRV up to $1000 \mathrm{cal}$. BP, and a sharper increase to approximately one landslide every 38 years from 1000 cal. BP to present. This increase in landslide frequency is mostly seen in the location of the knickzone, as predicted by conceptual models for landslides triggered by base level lowering.

The implications of these findings are that the rate of landsliding in the GRV has increased in the last 5,000 cal. BP. This is likely due to the climate becoming cooler and wetter and adjusting to base level. However, despite the change in climate there is still a minimum threshold relief of approximately 50 meters for any landsliding to occur. We can expect landsliding to increase upstream as the knickzone continues to adjust to base level. There are less urbanized areas upstream which could allow this to happen more naturally, whereas downstream in the more urbanized part of the valley the slopes are more bounded 
by roads and structures that might inhibit natural erosion rates and thus restrict landsliding. A recurrence interval of 26 landslides every 1000 years (one landslide every 38 years) is likely high. The younger the landslide, the more likely it's deposit will be preserved in the landslide inventory. Preservation bias, coupled with known seismic events, drastically increased the rate of landsliding in the last 1000 cal. BP in the Green River Valley. 


\section{References}

Allen, T.M., and S.M. Lowell (1995), Geotechnical Memorandum for SR 169 Green River Landslide. Washington State Department of Transportation.

Atwater, B. F., and A. L. Moore (1992), A tsunami about 1000 years ago in Puget Sound, Washington, Science, 258(5088), 1614-1616, doi:10.1126/science.258.5088.1614.

Anderson, R. S., Densmore, A. L., \& Ellis, M. A. (1999). The generation and degradation of marine terraces. Basin Research, 11(1), 7-19.

Arcos, M. E. M. (2012). The AD 900-930 Seattle-Fault-Zone Earthquake with a Wider Coseismic Rupture Patch and Postseismic Submergence: Inferences from New Sedimentary Evidence. Bulletin of the Seismological Society of America, 102(3), 1079-1098.

Booth, A. M., LaHusen, S. R., Duvall, A. R., \& Montgomery, D. R. (2017). Holocene history of deep-seated landsliding in the North Fork Stillaguamish River valley from surface roughness analysis, radiocarbon dating, and numerical landscape evolution modeling. Journal of Geophysical Research: Earth Surface, 122(2), 456472.

Booth, D. B., Haugerud, R. A., \& Troost, K. G. (2003). The geology of Puget lowland rivers. Restoration of Puget Sound Rivers. University of Washington Press, Seattle, 14-45.

Brubaker, L. B. (1991), Climate and the origin of old-growth Douglas-fir forests in the Puget Lowland, in Wildlife and Vegetation of Unmanaged Douglas-fir forests, edited by K. Aubry, pp. 17-24, USDA For. Serv. Gen. Tech. Rep. PNW-GTR-285.

Bucknam, R. C., E. Hemphill-Haley, and E. B. Leopold (1992), Abrupt uplift within the past 1700 years at southern Puget Sound, Washington, Science, 258(5088), 16111614, doi:10.1126/science.258.5088.1611.

Burns, W. J., \& Madin, I. (2009). Protocol for inventory mapping of landslide deposits from light detection and ranging (lidar) imagery (pp. 1-30). Portland, OR: Oregon Department of Geology and Mineral Industries.

Burns, W. J., \& Mickelson, K. A. (2016). Protocol for Deep Landslide Susceptibility Mapping. Oregon Department of Geology and Mineral Industries.

Caine, N. (1980). The rainfall intensity-duration control of shallow landslides and debris flows. Geografiska Annaler: Series A, Physical Geography, 62(1-2), 23-27. 
Cascadia Region Earthquake Workgroup (CREW), 2008, Cascadia deep earthquakes: Washington Division of Geology and Earth Resources Open File Report 2008-1, $26 \mathrm{p}$.

Chen, W., Li, X., Wang, Y., \& Liu, S. (2013). Landslide susceptibility mapping using LiDAR and DMC data: a case study in the Three Gorges area, China. Environmental earth sciences, 70(2), 673-685.

Clague, J. J. (1997). Evidence for large earthquakes at the Cascadia subduction zone. Reviews of Geophysics, 35(4), 439-460.

Costa, J. E., \& Schuster, R. L. (1988). The formation and failure of natural dams. Geological society of America bulletin, 100(7), 1054-1068.

Dahlquist, M. P., West, A. J., \& Li, G. (2018). Landslide-driven drainage divide migration. Geology, 46(5), 403-406.

Glenn, N. F., D. R. Streutker, D. J. Chadwick, G. D. Thackray, and S. J. Dorsch (2006), Analysis of Lidar-derived topographic information for characterizing and differentiating landslide morphology and activity, Geomorphology, 73(1-2), 131148, doi: 10.1016/j.geomorph.2005.07.006.

Gomberg, J., Sherrod, B., Weaver, C., \& Frankel, A. (2010). A Magnitude 7.1

Earthquake in the Tacoma Fault Zone-A Plausible Scenario for the Southern Puget Sound Region, Washington (No. 2010-3023). US Geological Survey.

Guzzetti, F., Peruccacci, S., Rossi, M., \& Stark, C. P. (2008). The rainfall intensityduration control of shallow landslides and debris flows: an update. Landslides, 5(1), 3-17.

Hanks, T. C. (2000). The age of scarplike landforms from diffusion-equation analysis. Quaternary Geochronology, 4, 313-338.

Haugerud, R. A. (2014), Preliminary interpretation of pre-2014 landslide deposits in the vicinity of Oso, Washington, U.S. Geological Survey Open-File Report 2014-1065.

Hutchinson, J. N., \& Bhandari, R. K. (1971). Undrained loading, a fundamental mechanism of mudflows and other mass movements. Geotechnique, 21(4), 353-358.

Iverson, R. M., George, D. L., Allstadt, K., Reid, M. E., Collins, B. D., Vallance, J. W., Schilling, S.P., Godt, J.W., Cannon, C.M., Magirl, C.S., Baum, R.L., Coe, J.A., Schulz, W.H., \& Bower, J.B. (2015). Landslide mobility and hazards: implications of the 2014 Oso disaster. Earth and Planetary Science Letters, 412, 197-208. 
Jacoby, Gordon, Patrick Williams, Brendan Buckley, 1992, Tree Ring Correlation Between Prehistoric Landslides and Abrupt Tectonic Events in Seattle, Washington, Science, 258.5088, p 1621-1623.

Jacoby, G. C., Bunker, D. E., \& Benson, B. E. (1997). Tree-ring evidence for an AD 1700 Cascadia earthquake in Washington and northern Oregon. Geology, 25(11), 9991002 .

Johnson, S., C. Potter, J. Armentrout, 1994, Origin and Evolution of the Seattle Fault and Seattle Basin, Washington, Geology, 22, p 71-74.

Johnson, S., S. Dadisman, J. Childs, W. Stanley, 1999, Active Tectonics of the Seattle Fault and Central Puget Sound, Washington-Implications for Earthquake Hazards, GSA Bulletin, 111.7, p 1042-1053.

Karlin, Robert, Mark Holmes, S.E.B. Abella, Richard Sylwester, 2004, Holocene Landslides And a 3500-year record of Pacific Northwest Earthquakes from Sediments in Lake Washington, GSA Bulletin, 116, doi:10.1130/B25158.1.

Keaton, J. R., Wartman, J., \& Montgomery, D. R. (2014). The 22 March 2014 Oso Landslide, Snohomish County, Washington (p. 228). Geotechnical Extreme Events Reconnaissance (GEER).

Keefer, D. K. (1984), Landslides caused by earthquakes, Geological Society of America Bulletin, 95(4), 406-421.

LaHusen, S. R., Duvall, A. R., Booth, A. M., \& Montgomery, D. R. (2016). Surface roughness dating of long-runout landslides near Oso, Washington (USA), reveals persistent postglacial hillslope instability. Geology, 44(2), 111-114.

Larsen, I. J., and D. R. Montgomery (2012), Landslide erosion coupled to tectonics and river incision, Nature Geoscience, 5(7), 468-473, doi:10.1038/ngeo1479.

Liberty, Lee, 2009, The Western Extension of the Seattle Fault: New Insights from Seismic Reflection Data, Center for Geophysical Investigation of the Shallow Subsurface, Department of Geosciences, Boise State University, p 1-16.

Marc, O., Hovius, N., \& Meunier, P. (2016). The mass balance of earthquakes and earthquake sequences. Geophysical Research Letters, 43(8), 3708-3716.

McCalpin, J. (1984), Preliminary age classification of landslides for inventory mapping, Proc. 21st Engineering Geology and Soils Engineering Symposium, 99-120. 
McKean, J., and J. Roering (2004), Objective landslide detection and surface morphology mapping using high-resolution airborne laser altimetry, Geomorphology, 57(3-4), 331-351, doi:10.1016/s0169-555x(03)00164-8.

Montgomery, D. R., \& Brandon, M. T. (2002). Topographic controls on erosion rates in tectonically active mountain ranges. Earth and Planetary Science Letters, 201(34), 481-489. doi: 10.1016/S0012-821X (02)00725-2.

Mullineaux, D. R. (1970). Geology of the Renton, Auburn, and Black Diamond quadrangles, King County, Washington (No. 672). United States Geologic Survey. US Govt. Print.

Neal, K.G. \& Coover, S.J. (1995). Geotechnical Feasibility and Impacts of Logging and Road Construction Green River Landslide King County, Washington for Plum Creek Timber Company, L.P. Puget Sound Unit, File Number 95-WAKI004. Kenneth Neal \& Associates. Internal Document.

Palmquist, R.C., Bible, G., 1980. Conceptual modelling of land- slide distribution in time and space. Bull. Int. Assoc. Eng. Geol. 21, 178-186.

Pánek, T. (2015). Recent progress in landslide dating: A global overview. Progress in Physical Geography, 39(2), 168-198.

Perkins, J. P., Reid, M. E., \& Schmidt, K. M. (2017). Control of landslide volume and hazard by glacial stratigraphic architecture, northwest Washington State, USA. Geology, 45(12), 1139-1142.

Pierson, T. C., Evarts, R. C., \& Bard, J. A. (2016). Landslides in the Western Columbia Gorge, Skamania County, Washington. US Geological Survey Scientific Investigations Map 3358.

Porter, S. C., and T. W. Swanson (1998), Radiocarbon age constraints on rates of advance and retreat of the Puget lobe of the Cordilleran ice sheet during the last glaciation, Quaternary 757 Research, 50(3), 205-213, doi:10.1006/qres.1998.2004.

Ramsey, C. B. (2001). Development of the Radiocarbon Calibration Program. Radiocarbon, 43 (2A), 355-363.

Rashed, T. M. (2003). Measuring the environmental context of social vulnerability to urban earthquake hazards: An integrative remote sensing and GIS approach. University of California, Santa Barbara. Book.

Roering, J. J., Kirchner, J. W., \& Dietrich, W. E. (2001). Hillslope evolution by nonlinear, slope-dependent transport: Steady state morphology and equilibrium adjustment timescales. Journal of Geophysical Research: Solid Earth, 106(B8), 16499-16513. 
Slaughter, S.L., Burns, W.J., Mickelson, K.A. Jacobacci, K.E., Biel, A.B., Contreras, T.A. (2017). Protocol for Landslide Inventory Mapping From Lidar Data in Washington State. Washington Geological Survey, Bulletin 82, 1-35.

Thorsen, G. W. (1989). Landslide provinces in Washington. Engineering Geology in Washington, Richard W. Galster, ed.: Washington Division of Geology and Earth Resources Bulletin, 78, 71-89.

Vallance, J. W., \& Scott, K. M. (1997). The Osceola Mudflow from Mount Rainier: Sedimentology and hazard implications of a huge clay-rich debris flow. Geological Society of America Bulletin, 109(2), 143-163.

Vine, J. D. (1969). Geology and coal resources of the Cumberland, Hobart, and Maple Valley quadrangles, King County, Washington (No. 624). US Govt. Print.

Wartman, J., Montgomery, D. R., Anderson, S. A., Keaton, J. R., Benoît, J., dela Chapelle, J., \& Gilbert, R. (2016). The 22 March 2014 Oso landslide, Washington, USA. Geomorphology, 253, 275-288.

Yamaguchi, D. K., Atwater, B. F., Bunker, D. E., Benson, B. E., \& Reid, M. S. (1997). Tree-ring dating the 1700 Cascadia earthquake. Nature, 389(6654), 922.

Yeats, Robert, 2004, Living with Earthquakes in the Pacific Northwest, Oregon State University Press, https://openoregonstate.pressbooks.pub/earthquakes/.

Zhang, H., Zhang, P., Champagnac, J. D., Molnar, P., Anderson, R. S., Kirby, E., \& Liu, S. (2014). Pleistocene drainage reorganization driven by the isostatic response to deep incision into the northeastern Tibetan Plateau. Geology, 42(4), 303-306. 